INTER NATIONAL MONETARY FUND
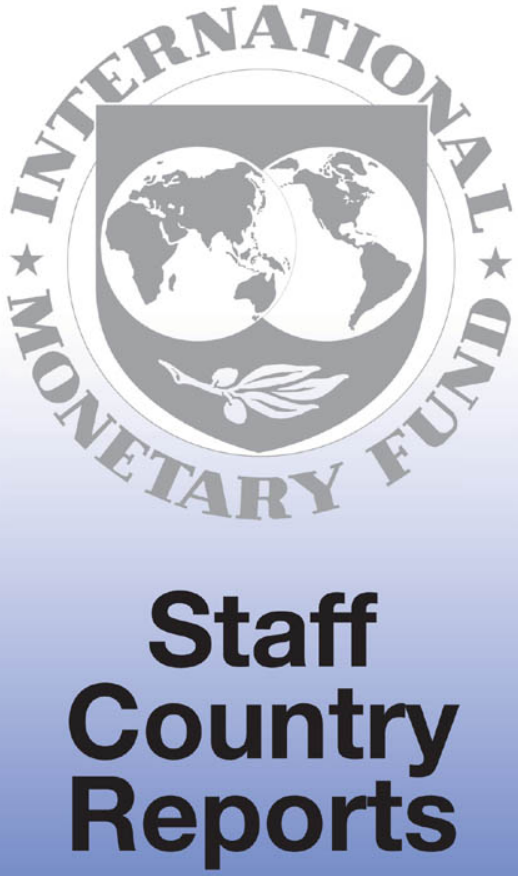


\title{
Czech Republic: Financial System Stability Assessment, including Reports on the Observance of Standards and Codes on the following topics: Monetary and Financial Policy Transparency; Banking Supervision; Insurance Regulation; Securities Regulation; Corporate Governance; and Payment Systems
}

The Financial System Stability Assessment on the Czech Republic was prepared by a staff team of the International Monetary Fund as background documentation for the periodic consultation with the member country. It is based on the information available at the time it was completed on June 25,2001 . The views expressed in this document are those of the staff team and do not necessarily reflect the views of the government of the Czech Republic or the Executive Board of the IMF.

The policy of publication of staff reports and other documents by the IMF allows for the deletion of market-sensitive information.

To assist the IMF in evaluating the publication policy, reader comments are invited and may be sent by email to Publicationpolicy@imf.org.

\author{
Copies of this report are available to the public from \\ International Monetary Fund - Publication Services \\ 700 19th Street, N.W. - Washington, D.C. 20431 \\ Telephone: (202) 6237430 - Telefax: (202) 6237201 \\ E-mail: publications@imf.org • Internet: http://www.imf.org \\ Price: $\$ 15.00$ a copy \\ International Monetary Fund \\ Washington, D.C.
}




\title{
INTERNATIONAL MONETARY FUND
}

\section{CZECH REPUBLIC}

\section{Financial System Stability Assessment}

\author{
Prepared by the Monetary and Exchange Affairs and European I Departments
}

\author{
Approved by V. Sundararajan and Jacques R. Artus
}

June 25, 2001

The Financial Sector Stability Assessment (FSSA) is based on the work of a joint IMF-World Bank mission that visited Prague as part of the Financial Sector Assessment Program (FSAP) from November 28 to December 12, 2000 and February 13 to February 22, 2001. The staff met with senior management of the Czech National Bank (CNB), the Ministry of Finance (MoF), the Ministry of Justice (MoJ), the Czech Securities Commission (CSC), the Prague Stock Exchange (PSE), the accounting, auditors', and bankers' associations, as well as representatives of the financial sector. The findings of the FSAP missions were updated during April 11-13, 2001 in the context of the 2001 Article IV Consultation discussions.

The mission was led by Hassanali Mehran (IMF, Mission Chief) and Roberto Rocha (World Bank, Deputy Mission Chief), and comprised Ame B. Petersen, Udaibir S. Das, Edward Frydl, Dimitri Tzanninis, Plamen Yossifov, Ms. Nadia Malikyar and Ms. Maria Tramuttola (Administrative Assistants) (all IMF); Dimitri Vittas, Jeppe Ladekarl, Luc Laevan, Donald McIsaac, Douglas Webb, Gordon Johnson (all World Bank); Andrew Beadle (IMF Expert, U.K. FSA); James Dingle (IMF Expert, Bank of Canada); Andrew Procter (World Bank Expert, Hong Kong Securities and Futures Commission); and Antonio Jose Vieira Aguas (IMF Expert, Bank of Portugal). The mission was assisted in the field by Mr. Roger Nord, IMF's Regional Representative in Central Europe.

The Czech financial system is near the completion of a fairly rapid phase of restructuring and reform aimed at addressing the earlier crisis and at restoring and improving its stability and efficiency. Considerable progress has been made in improving the legislative and regulatory framework. Institutional strengthening has been accompanied by enhanced prudential oversight, extensive carve-out of bad assets, privatization of large banks to foreign strategic investors, and a significant consolidation of banks and non-bank financial institutions. The level of nonperforming loans that will be left in the banking system after the imminent completion of the carve-out of bad assets appears manageable given current provisioning levels. Moreover, stress tests indicate that the Czech system shows only moderate vulnerability to risks. Nevertheless, challenges remain. Bank restructuring and privatization need to be completed and the high fiscal costs of bank restructuring must be addressed. Fiscal costs of bank restructuring are increasing macroeconomic pressures at a time when the budget deficit is already large and rising. Large FDI flows and slow credit growth have thus far neutralized the potential negative effects of the large fiscal deficits on the financial sector and on the external accounts. Enforcement of the legal and regulatory framework needs to be further enhanced, requiring a build up of supervisory capacity, a more proactive approach by self-regulatory organizations (SROs), and improvements in the court system. Supervisory objectives should be further oriented towards monitoring the soundness of financial institutions on a consolidated basis. To enable more effective monitoring of the activities of integrated firms and markets, coordination and cooperation between supervisory agencies requires increased attention.

The report has two sections: the first section presents the main findings and overall assessment. The second section presents a summary assessment of observance of standards and codes relating to banking supervision, payment systems, securities regulation, insurance supervision, corporate governance, and transparency in monetary and financial policies. The FSAP reports containing detailed institutional information and analysis, as well as detailed assessments of the observance of standards and codes, were transmitted to the authorities in June 2001.

The main authors of this report are Arne B. Petersen and Udaibir S. Das (both MAE). 
Executive Summary and Overall Stability Assessment ...............................................................6

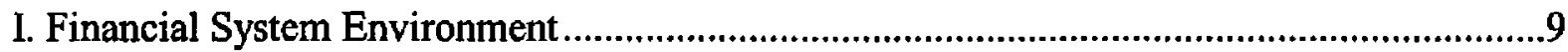

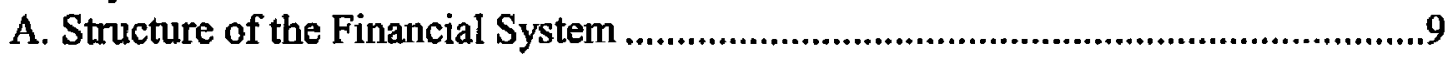

B. Regulatory and Supervisory Framework ............................................................11

C. Market Infrastructure and Payment Systems .........................................................13

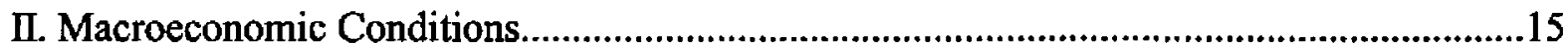

A. Macroeconomic Setting .......................................................................................15

B. Sources of Macroeconomic Risks Impacting the Financial System.........................16

C. Monetary Policy Operations .............................................................................17

III. Vulnerabilities and Soundness of the Banking System and Linkages with the Corporate Sector .........................................................................17

A. The Banking Sector .................................................................................17

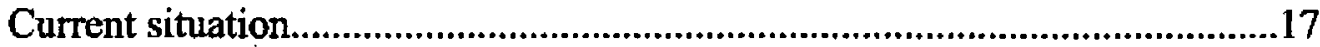

Origin of the large stock of nonperforming loans..............................................18

Restructuring of the banks ..............................................................................19

Cost to the government ..................................................................................21

Performance, stress testing, and future stability............................................21

Banking supervisory vulnerabilities................................................................24

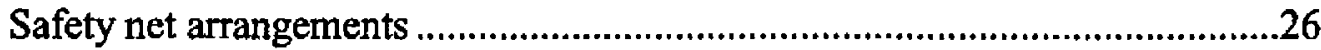

B. Corporate Sector and the Financial System........................................................26

IV. Vulnerabilities and Soundness of the Nonbank Financial System .....................................29

A. Securities Markets and Collective Investment Institutions ..................................29

B. Insurance Sector ...................................................................................30

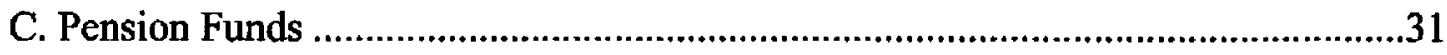

D. Other Nonbank Financial Institutions ..............................................................31

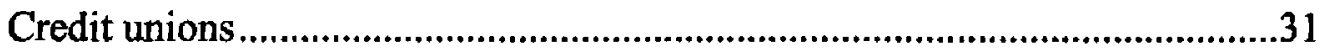

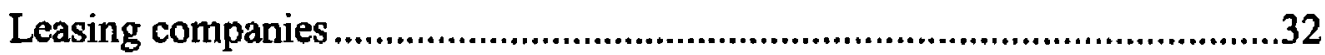

V. Ensuring Stability: Summary of Key Recommended Actions

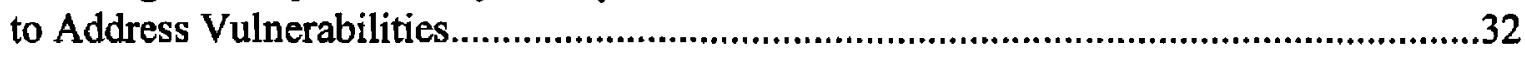

Part II. Financial Sector ROSC Modules (FSRMs) ……….................................................37

VI. Transparency of Monetary Policy................................................................................38

Legal framework, institutions, and market structure-overview.....................38

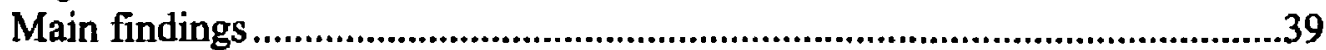

Recommended action plan and authorities' response........................................41

VII. Basel Core Principles for Effective Banking Supervision and Transparency of Banking Supervision 


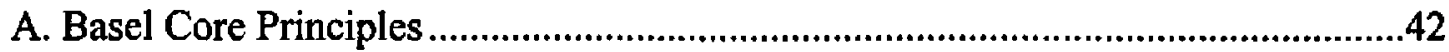

Institutional and macroprudential setting, market structure-overview...........43

Preconditions for effective banking supervision............................................44

Main findings ...........................................................................................45

Recommended action plan and authorities' response.........................................47

B. Transparency of Banking Supervision ...................................................................48

Institutional and market structure-overview...............................................49

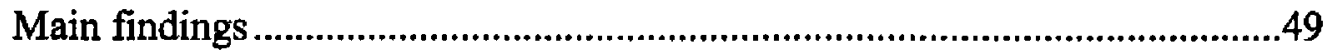

Recommended action plan and authorities' response.........................................51

VIII. IAIS Core Principles and Transparency of Insurance Regulation ..................................51

A. IAIS Insurance Core Principles ...........................................................................51

Institutional and market structure-overview.................................................52

General preconditions for effective insurance supervision...............................53

Main findings ....................................................................................................54

Recommended action plan and supervisory response to the assessment..........55

B. Transparency of Insurance Regulation .................................................................58

Institutional and market structure-overview.............................................58

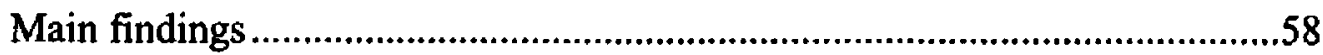

Recommended action plan and authorities' response.......................................60

IX. IOSCO Objectives and Principles of Securities Regulation

and Transparency of Securities Regulation...............................................................62

A. IOSCO Objectives and Principles of Securities Regulation ...................................62

Supervisory framework ........................................................................62

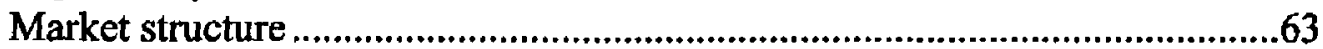

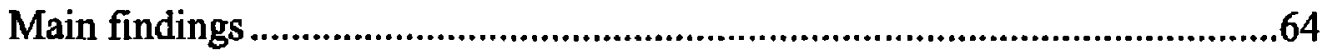

Recommended action plan and authorities' response to the assessment .........66

B. Transparency of Securities Regulation...................................................................67

Institutional and market structure - overview...............................................68

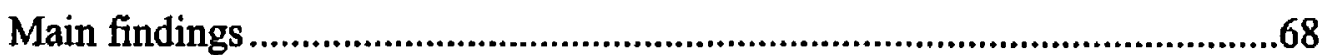

Recommended action plan and authorities' response....................................70

X. OECD Corporate Governance Principles......................................................................70

The legal framework affecting corporate governance...................................71

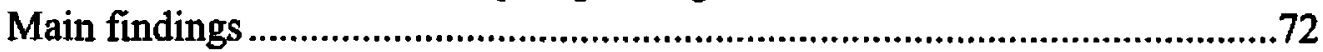

XI. CPSS Core Principles for Systemically Important Payment Systems and Transparency of Payment System Oversight............................................................73

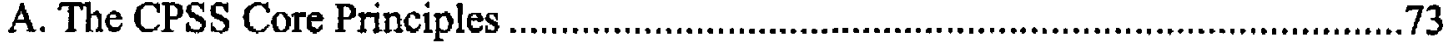

Institutional setting and market structure .......................................................73

General preconditions-overview ............................................................74

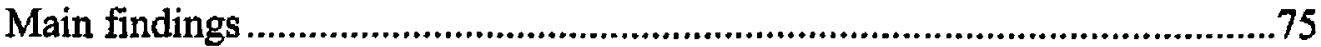

B. Transparency of Payment Systems Oversight .......................................................75

Institutional and market structure-overview...........................................76

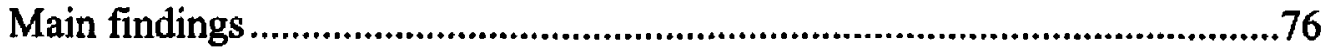

Recommended action plan and authorities' response....................................77 
Text Tables

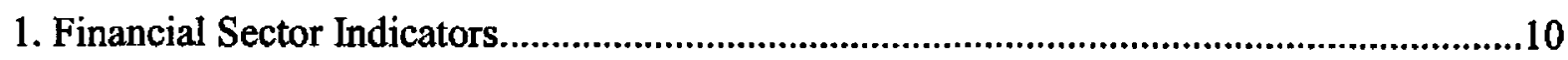

2. Projected Loan Portfolio and Contingent Risk Exposure of KOB Group ...........................20

3. First-Round Results of Stress Tests of Macroprudential Indicators .................................22

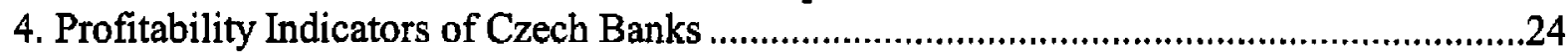

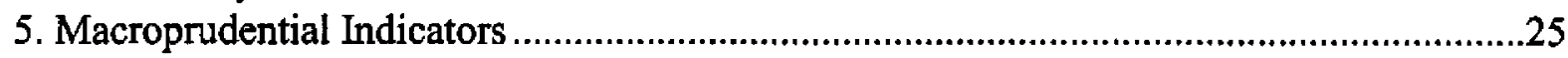

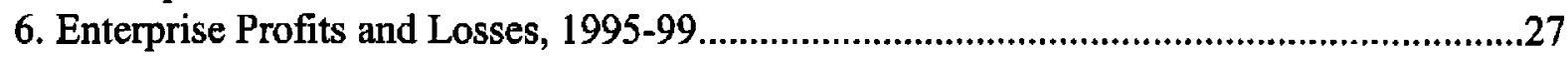

7. Debt-Equity Ratios in Different Segments of the Corporate Sector, 1999 .......................28

8. Monetary Policy Transparency: Assessment Recommendations......................................41

9. Summary of Main Findings and Recommendations ....................................................47

10. Banking Supervision Transparency: Assessment Recommendation ...............................51

11. Summary of Main Findings of Assessment of Observance of the IAIS Insurance

Supervisory Principles

12. Insurance Regulation Transparency: Assessment Recommendations ......................60

13. Summary of Main Findings and Recommendations ..............................................64

14. Securities Regulation Transparency: Assessment Recommendations ..............................70

15. Summary of Main Findings of the Core Principles for

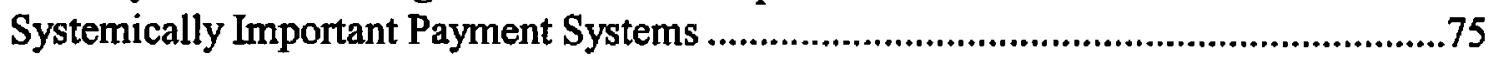

16. Payment Systems Transparency: Assessment Recommendations ................................77

Figures

1. Czech Republic: Structure of the Financial System in a Comparative Perspective.............11

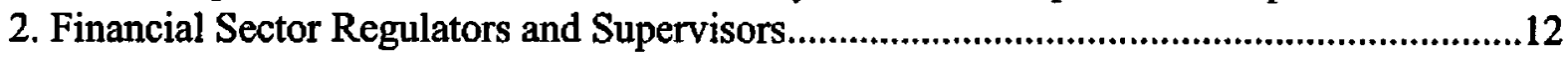

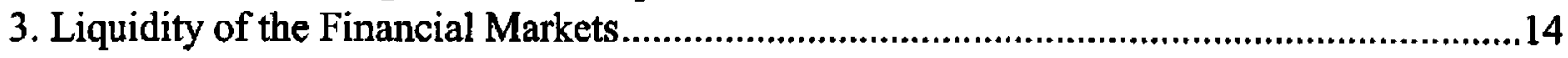

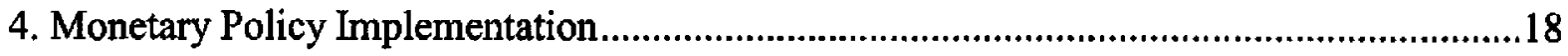

Boxes

1. Debt Enforcement Vulnerabilities 
GLOSSARY

$\begin{array}{ll}\text { AMC } & \text { asset management company } \\ \text { CNB } & \text { Czech National Bank } \\ \text { CSC } & \text { Czech Securities Commission } \\ \text { CSO } & \text { Central Statistical Office } \\ \text { CZK } & \text { Czech koruna } \\ \text { CUSA } & \text { Credit Union Supervisory Authority } \\ \text { DIF } & \text { Deposit Insurance Fund } \\ \text { EU } & \text { European Union } \\ \text { FDI } & \text { foreign direct investment } \\ \text { FSAP } & \text { Financial Sector Assessment Program } \\ \text { FSRMs } & \text { Financial Sector ROSC Modules } \\ \text { FSSA } & \text { Financial System Stability Assessment } \\ \text { IAIS } & \text { International Association of Insurance Supervisors } \\ \text { ICP } & \text { IAIS Core Principles for Insurance Supervision } \\ \text { IOSCO } & \text { International Organization of Securities Commissions } \\ \text { IPB } & \text { Investicni a Postovni banka } \\ \text { KOB } & \text { Konsolidacní banka Praha } \\ \text { MoF } & \text { Ministry of Finance } \\ \text { MOU } & \text { Memorandum of Understanding } \\ \text { NPLs } & \text { nonperforming loans } \\ \text { OCG } & \text { OECD Principles of Corporate Governance } \\ \text { PSE } & \text { Prague Stock Exchange } \\ \text { SCP } & \text { IOSCO Objectives and Principles of Securities Regulation } \\ \text { SDDS } & \text { Special Data Dissemination Standard } \\ \text { SRO } & \text { self-regulatory organizations } \\ \end{array}$




\section{PaRt I-STAFf Report on Financial Sector Issues}

\section{EXECUTIVE SUMmaRY AND OVERALL STABILITY ASSESSMENT}

\section{A. Macroeconomic Environment and the Financial System}

1. The resilience of the Czech financial system to macroeconomic shocks and structural weaknesses has strengthened considerably as a result of recent reform efforts. The rapid phase of restructuring and reform underway has been a significant improvement over the initial wave of reforms in the early to mid-1990s, which did not fully address deeply rooted structural problems inherited from the pre-transition and early transition periods. The protracted recession during the late 1990s exposed severe weaknesses of the Czech financial system.

2. Key reform measures have included substantial carve-out of bad assets, privatization of large state banks to foreign strategic investors, a significant consolidation of banks and nonbank financial institutions, and improvements in the prudential and legislative framework. When the last large state bank is privatized later this year, 90 percent of the banking system will be owned by reputable foreign banks. Progress in the financial and enterprise restructuring, combined with appropriate policy response by the Czech authorities to a favorable external sector and sustained foreign direct investment (FDI) has laid the foundation for growth with a rebound in activity since mid-1999.

\section{Stress tests indicate that the Czech banking system now shows only moderate} vulnerability to market and credit risks. The level of nonperforming loans (NPLs) that will be left in the banking system after the carve-out of bad assets appears manageable given current provisioning levels. However, profit margins are thin, and should banks resume lending aggressively in an attempt to increase profitability, they may take on additional market and credit risks.

4. The clean-up of bank balance sheets has come at a large cost to the government (estimated at the equivalent of 21 percent of GDP, when fully budgeted), which add to the fiscal pressures. Thus far there has been no measurable impact on inflation and on the external sector, because of FDI inflows, relatively low private demand, and the fact that clean-up expenditures mainly have covered book losses with little direct impact on aggregate demand. However, the outlook could deteriorate drastically in the absence of fundamental fiscal reform. The widening fiscal deficit could translate into growing external imbalances, undermine confidence and possibly result in a depreciation of the koruna. Even otherwise, the Czech National Bank (CNB) may have to raise interest rates substantially at some point to prevent inflation, creating a situation in which high interest rates, real appreciation of the koruna, and large current account deficits would coexist. This could affect growth prospects and contribute to rising non-performing loans and bankruptcies.

5. Monetary policy in the Czech Republic is being conducted in an environment of excess liquidity in the banking sector. The two-week repo tender of CNB bills is being 
aggressively used for absorption of excess liquidity and sterilization of the sustained capital inflows. Escalating interest expenses associated with the CNB's repo operations could result in quasi-fiscal losses.

6. The fixed-income and the foreign-exchange markets are sufficiently developed to weather liquidity runs. However, the interbank money market and the stock market require deepening in order to accommodate large portfolio adjustments without significant effect on prices and market volatility. Given the current state of excess liquidity in the banking sector and the relatively small capitalization of the stock market, however, these market weaknesses are unlikely to pose any systemic threat in the near future. Payment and settlement infrastructure is broadly in place to support transparent and reliable money and capital market operations.

7. The nonbank sector, except insurance, is also undergoing consolidation and does not pose any immediate stability related concern. Continuous improvement in prudential regulations and elimination of weak financial institutions through withdrawal of licenses, liquidations, and mergers is underway. The insurance sector seems to be well-capitalized and profitable but may also have to undergo consolidation due to increasing competition.

\section{High priority is being placed on implementing and observing the international} standards relevant for financial stability, and good progress has been made. This effort has been spurred by the prospects of EU accession and the attempts at institutional and legal reform at harmonizing with the EU standards. Consequently, a massive effort is underway to enhance the regulatory, supervisory and transparency framework and strengthen the market infrastructure. In banking supervision, areas needing strengthening include consolidated supervision and risk based supervision emphasizing the need for more rigorous monitoring of risk-adjusted capital adequacy positions. In insurance supervision, the major shortcoming is the failure to conduct on-site inspections with any frequency and with a risk focus. The supervisory authority also lack sufficient legal and operational independence. In the area of securities regulation, there are practical limitations relating to the supervisory capacity of the Czech Securities Commission (CSC).

\section{B. Risks and Vulnerabilities: Challenges and Strategic Priorities}

9. While the progress made so far has considerably reduced the vulnerabilities of the Czech financial and corporate sectors to risk factors, the system continues to face several critical challenges. These include: (1) pursuing stable macroeconomic policies; (2) completing the banking privatization and restructuring program in an orderly fashion;

(3) implementing speedily a workout program for the large stock of bad assets; and

(4) strengthening supervisory coordination and regulatory enforcement framework, and market infrastructure.

10. Bank restructuring and privatization need to be completed and the high fiscal costs of bank restructuring must be addressed. Fiscal costs of bank restructuring are increasing macroeconomic pressures at a time when the budget deficit is already large and rising. The bank restructuring program will add significantly to the levels of debt and deficits. 
Privatization revenues have provided a temporary palliative, and large FDI flows have neutralized the potential negative effects of large fiscal deficits on the financial sector and on the external accounts. However, the sustainability of the FDI flows cannot be taken for granted.

11. A large stock of nonperforming loans, amounting to roughly 25 percent of GDP, remains to be worked out. A successful workout program necessitates improvements in the parts of the legal framework, such as insolvency, that have fallen behind. This is essential in order to expedite enterprise restructuring and obtain a better price in the auction of bad assets. Failure to resolve this critical aspect of the bank and corporate restructuring process is likely to result in low recovery rates, given the current long delays in the resolution of bad assets.

\section{The legal and regulatory framework has been improved, but enforcement has} remained unsatisfactory. The issue is gaining in importance given the growing interconnectedness in the financial system, consolidation of the financial system, and the resulting predominant control of foreign investors. Better enforcement will require a strong build up of supervisory capacity, a more proactive approach by self-regulatory organizations (SROs), and improvements in the court system.

\section{Supervisory objectives need to be further oriented towards monitoring the} soundness of financial institutions on a consolidated basis. Quantitative prudential standards require supplementing with a more qualitative approach based on risk management and market discipline. In addition, more transparent operating procedures need to be adopted by the supervisors, SROs, and financial participants, leading to greater accountability and improved market discipline. Finally, corporate governance of financial institutions also needs strengthening.

\section{To enable more effective monitoring of the activities of integrated firms and} markets, coordination and cooperation between supervisory agencies requires strengthening. The interlocking ownership structures, the episode relating to the privatization of Investicni a Postovni banka (IPB), the collapse of the credit union sector, and the general tendency, thus far, of forbearance clearly point to the need for a supervisory framework that closely monitors and oversees all members of a financial group. While it may be premature to consider a single consolidated supervisory body, lines of accountability among the supervisory authorities need to be made explicit and a regulatory committee (collegium) should be set up to consider cross-sectoral issues on a regular basis. Serious consideration should also be given to make insurance supervision autonomous.

\section{Regarding the nonbanking sectors, the adoption of the mutual fund model for} pension funds would improve transparency and needs to be implemented as soon as possible. In the area of securities supervision, the CSC must complete the main structural reforms initiated in 1998 . The supervisory capacity should be strengthened further and move from a formal monitoring of compliance with regulations to a more proactive, focused and risk-based supervisory system. 


\section{Financial SYSTEM ENVIRONMENT}

\section{A. Structure of the Financial System}

16. The Czech Republic has a relatively large financial sector for a middle-income country - total assets of roughly 122 percent of GDP - that is fast becoming diversified. The banking sector dominates, accounting for 88 percent of total assets (Table 1 and Figure 1). The high ratio of banking sector assets to GDP in the Czech Republic is in good part due to the smaller inflationary erosion of balance sheets, relative to other transitional countries. Therefore, this is not necessarily an indication of a deeper and more developed banking system in comparison with other advanced transitional countries.

17. Impressive process of consolidation is indicated by the sharp reduction in the number of licensed banks from 55 in the mid-1990s, to 40 in 2000. The decline in the total number of banks is essentially due to the elimination of several troubled small and medium banks (mostly domestically owned) during the second half of the 1990s. Since 1997, the Czech authorities have privatized three of the four large state banks, and the privatization of the fourth large state bank is expected to be concluded in 2001. In part in preparation of the sales, a large amount of nonperforming loans have been taken over by a consolidation bank (Konsolidační banka Praha-KOB), at a significant fiscal cost to the government. After the conclusion of the privatization program, foreign strategic investors will control roughly 90 percent of assets in the banking sector.

\section{The number of licensed nonbank institutions has declined by more than} 50 percent in most sectors (except insurance), as a result of continuous improvement in prudential regulations and elimination of weak financial institutions through withdrawal of licenses, liquidations, and mergers. The mutual funds sector has been undergoing a dramatic consolidation, due primarily to the mandatory opening of closed-end funds. The pension fund sector that started in 1994 has also undergone consolidation. The number of companies listed and traded in the Prague Stock Exchange (PSE) has also been reduced dramatically through the introduction of stricter listing requirements. In the insurance sector, the non-life business accounts for two-thirds of total premiums and assets, and compares well with other transitional countries. However, the life insurance business remains relatively undeveloped. The sector seems to be well-capitalized and profitable.

19. The consolidation of the financial sector has resulted in a large share of financial assets controlled by foreign strategic investors. This phenomenon has occurred across almost all segments of the financial sector and can be expected to strengthen the capital positions and bring about improvements in governance and range and quality of financial services. However, the Czech financial sector may still witness further consolidation, especially in view of the prospects of EU membership and its integration in the competitive common EU market. 
Table 1. Czech Republic: Financial Sector Indicators 1/

\begin{tabular}{lrrrrrr}
\hline Structure of financial sector/Ref. period & 1995 & 1996 & 1997 & 1998 & 1999 & 2000 \\
\hline & \multicolumn{7}{c}{ Total assets (In billions of korunas) } \\
$\begin{array}{l}\text { All financial institutions } \\
\text { of which }\end{array}$ & $\ldots$ & 1,976 & 2,314 & 2,417 & 2,530 & $\ldots$ \\
$\quad \begin{array}{l}\text { Deposit money banks 2/ } \\
\text { Insurance companies }\end{array}$ & 1,472 & 1,709 & 2,069 & 2,166 & 2,229 & 2,328 \\
$\quad$ Investment funds 3/ & 92 & 125 & 126 & 134 & 151 & $\ldots$ \\
$\quad \begin{array}{l}\text { Pension funds 4/ } \\
\text { Memo item }\end{array}$ & 7 & 119 & 95 & 86 & 112 & 113 \\
Gross domestic product & 24 & 23 & 31 & 37 & 40 \\
& 1,381 & 1,572 & 1,669 & 1,798 & 1,833 & 1,911
\end{tabular}

Relative share in total assets of the financial sector (In percent)

All financial institutions of which

Deposit money banks Insurance companies Investment funds

Pension funds

$\begin{array}{rrrrrr}\ldots & 100 & 100 & 100 & 100 & \ldots \\ \ldots & 86 & 89 & 90 & 88 & \ldots \\ \ldots & 6 & 5 & 6 & 6 & \ldots \\ \ldots & 6 & 4 & 4 & 4 & \ldots \\ \ldots & 1 & 1 & 1 & 1 & \ldots\end{array}$

Size of total assets relative to GDP (In percent)

All financial institutions of which

Deposit money banks Insurance companies Investment funds Pension funds

\begin{tabular}{rrrrrr}
$\ldots$ & 126 & 139 & 134 & 138 & $\ldots$ \\
$\ldots$ & 109 & 124 & 120 & 121 & 122 \\
$\ldots$ & 8 & 8 & 7 & 8 & $\ldots$ \\
$\ldots$ & 8 & 6 & 5 & 6 & 6 \\
$\ldots$ & 2 & 1 & 2 & 2 & 2 \\
\multicolumn{7}{r}{} & Number of financial institutions & & \\
55 & 53 & 50 & 45 & 42 & 40 \\
35 & 35 & 40 & 41 & 42 & 42 \\
$\ldots$ & 469 & 350 & 270 & 198 & 189 \\
44 & 44 & 44 & 30 & 24 & 20 \\
154 & $\ldots$ & $\ldots$ & $\ldots$ & $\ldots$ & 93 \\
619 & $\ldots$ & $\ldots$ & $\ldots$ & $\ldots$ & 190 \\
$\ldots$ & $\ldots$ & $\ldots$ & $\ldots$ & 122 & $\ldots$
\end{tabular}

All financial institutions

of which

Deposit money banks Insurance companies Investment funds

Pension funds

Credit unions 5/

Securities firms 6/

Leasing companies $7 /$

Sources: the CNB, MoF and CSC.

1/ Only types of financial institutions, for which there is data for the respective indicators, appear in the table. 2/ Data from the statistical reports submitted by the CNB to the IMF. Data adjusted by netting out interbank deposits and correcting for the double counting of repos of CNB bills in official statistics.

3/ End of June 2000 data. Includes closed-end investment privatization funds structured as joint-stock companies, closed-end unit trusts, and open-end unit trusts.

4/ End of June 2000 data.

5/ Total assets of the 93 credit unions that held licenses at the end of 2000 were an estimated CZK 10.4 billion, or 0.5 percent of GDP.

6/ Data on asset management companies (153 in 1995, 75 in 2000) and brokerage firms (466 in 1995, 115 in 2000).

7/ Data for members of the Czech Association of Leasing Companies only. At the end of 1999, the latter accounted for 95 percent of the domestic leasing market and had combined assets of CZK 142 billion or 7.7 percent of GDP. 
Figure 1. Czech Republic: Structure of the Financial System in a Comparative Perspective (End of 1998)

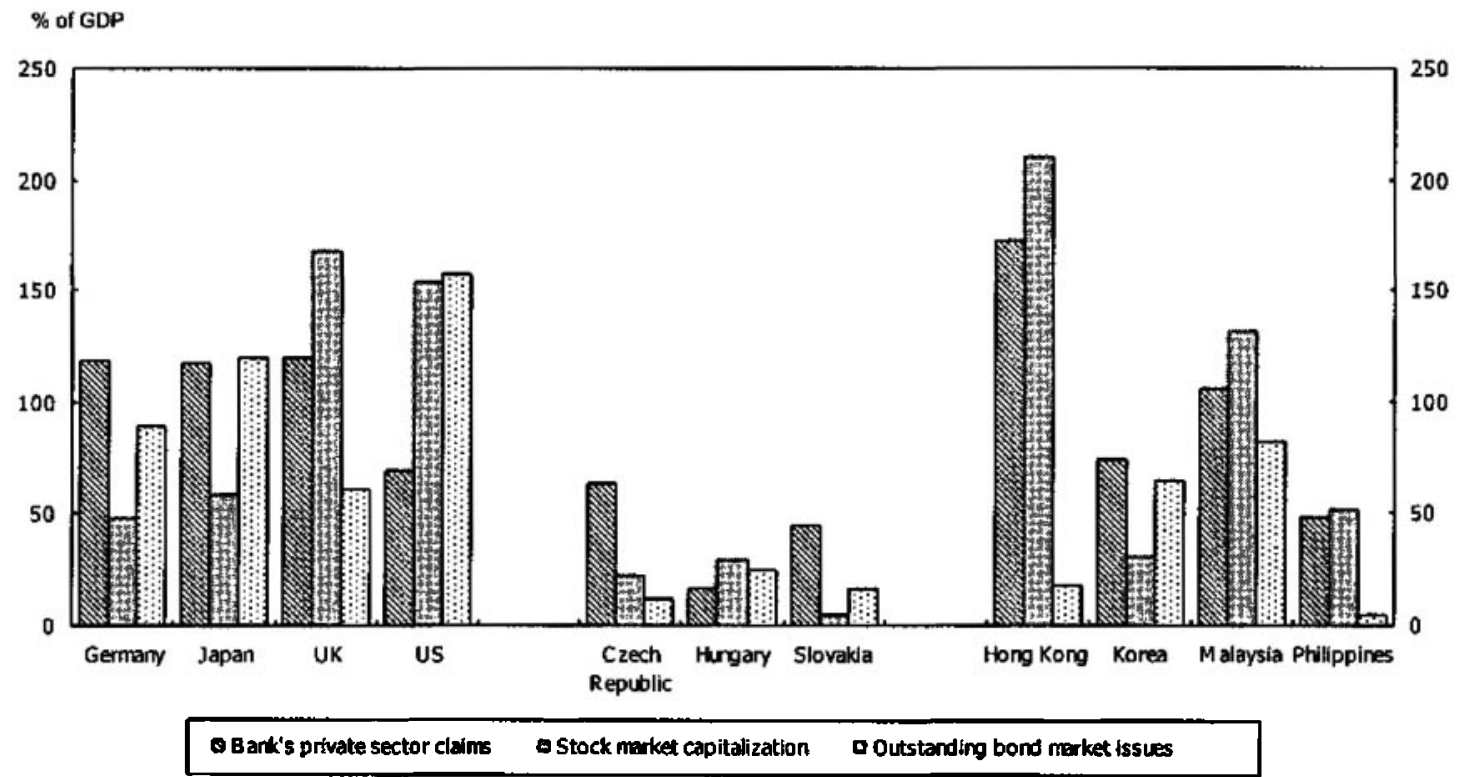

20. The number of financial conglomerates has been on the rise. Typically bank-led, and comprising of building savings banks, insurance company, investment company managing mutual funds, and other types of financial companies, especially asset management companies (AMCs), there were 18 such financial groups operating in the Czech Republic as of December 2000. Of these, however, only five bank groups were significant in terms of the market share.

\section{B. Regulatory and Supervisory Framework}

21. Significant progress has been made in the legislative and regulatory framework aimed towards harmonization with international standards relating to financial sector supervision and regulation. There are, however, areas where further improvement is necessary to reduce vulnerabilities and strengthen the framework within which the financial system operates. In particular, capacity constraints and administrative and judicial processes are proving a major constraint toward the full observance of the internationally accepted regulatory standards.

22. The degree of autonomy varies across the supervisory agencies (Figure 2). While the CNB has the authority to issue secondary legislation covering the regulation of the banking system, the CSC's powers are extremely limited. The Ministry of Finance (MoF) has retained responsibility for basic policy formation, the submission of new legislation to 
parliament, and for enactment of secondary legislation relating to the securities market. Supervision of insurance companies and pension funds is undertaken by the Office of Supervision inside the MoF, which again has very limited legal and operational independence. The supervision of pension funds is expected to be shifted to the CSC in January 2002. Finally, the Credit Union Supervisory Authority (CUSA), which is under the $\mathrm{MoF}$ and supervises the credit union sector, has no rule-issuing powers, very little operational independence, and limited supervisory capability.

Figure 2. Financial Sector Regulators and Supervisors

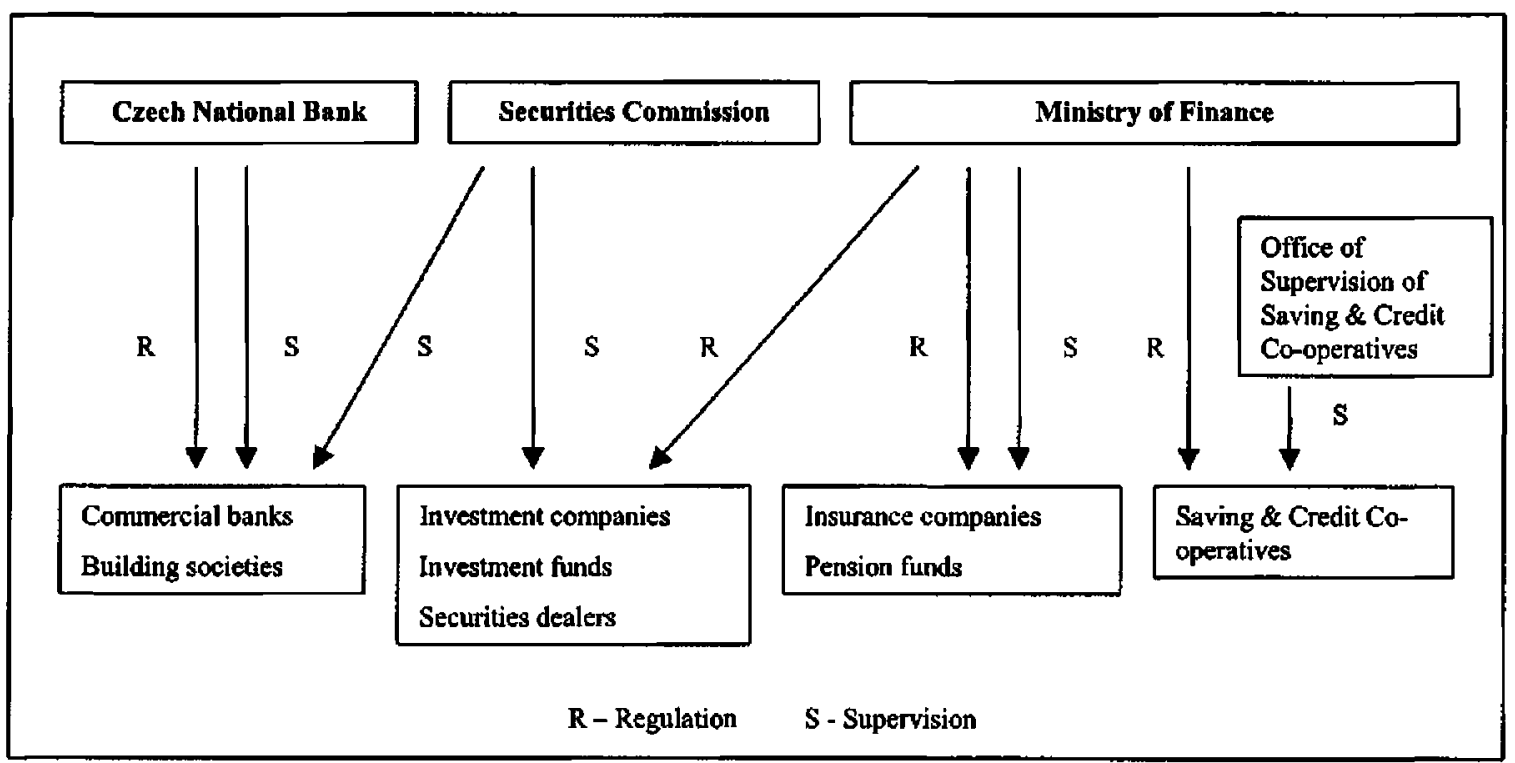

23. The growth of diversified financial groups in the Czech Republic places a premium on effective coordination among the regulatory agencies. Currently, information exchange between the CNB, the $\mathrm{MoF}$, and the CSC is undertaken under a trilateral agreement that has been in place since 1998. Working groups have been established on licensing, consolidated supervision, disclosure, and on-site examinations. In practice, legal obstacles (on the part of the MoF) and other administrative procedures have hampered the system of information sharing. Discussions between the agencies have tended to focus on limit breaches and criminality rather than on the underlying risks facing each financial group, and licensed entities. Cooperation between supervisors needs strengthening through a clearer mechanism, such as a supervisory committee or collegium. While a single supervisory body could be considered at some stage, energies at present could better be focused on enhancing the operations of existing bodies. 


\section{Market Infrastructure and Payment Systems}

24. The main financial markets in the Czech Republic are the interbank money market, the stock market, the fixed income market, and the foreign exchange market. In periods of financial distress, such as the May 1997 currency crisis and the spill-overs from the Russian crisis, the interbank money market and the stock market have shown to be lacking in depth and resilience to accommodate large portfolio adjustments without significant effect on prices and market volatility.

25. The developments in the spread between the bid and ask quotes on the Prague interbank money market in times of financial crises and their aftermath reveal difficulty in readjusting efficiently (Figure 3). During the May 1997 crisis, the ask-bid spread shot up and did not return to its pre-crisis average value until September 1997, only to surge to new heights in the fourth quarter in response to another wave of domestic currency depreciation.

26. An analysis of trading on the PSE shows a clear correlation between the value of the PX50 index and trading volumes. In particular, periods of rising stock prices are associated with high trading volumes, whereas as the stock prices fall-the liquidity disappears from the market. In the aftermath of the Russian crisis, the main index of the PSE fell from 503 to 318 basis points between July 21 and October 8, 1998. This sharp market downturn led to a significant increase in stock price volatility, which has remained above its pre-crisis average value. The PSE has, however, succeeded in creating a minimum market liquidity for the seven main traded stocks with the setting up of the SPAD trading system in 1999. This should mitigate the impact of future runs on liquidity on the stability of the stock market.

27. Historic analysis of the liquidity of the fixed income and foreign exchange markets has shown that they are sufficiently developed to weather shocks. Larger government deficits in the recent years have resulted in a steep increase in the number and value of government bonds listed on the PSE. The stock of domestic central government debt at the end of 2000 was equivalent to roughly 15 percent of GDP. A potentially serious problem and vulnerability in debt management is the short average maturity of the debt stock.

28. The currency crisis in May 1997 resulted in only short-lived volatility in the foreign exchange market. Moreover, whereas pressures on the exchange rate during the subsequent Russian financial crisis did temporarily raise market volatility, market uncertainty did not affect significantly the bid-ask spread and the ability of market participants to manage their liquidity. 
Figure 3. Czech Republic: Liquidity of the Financial Markets
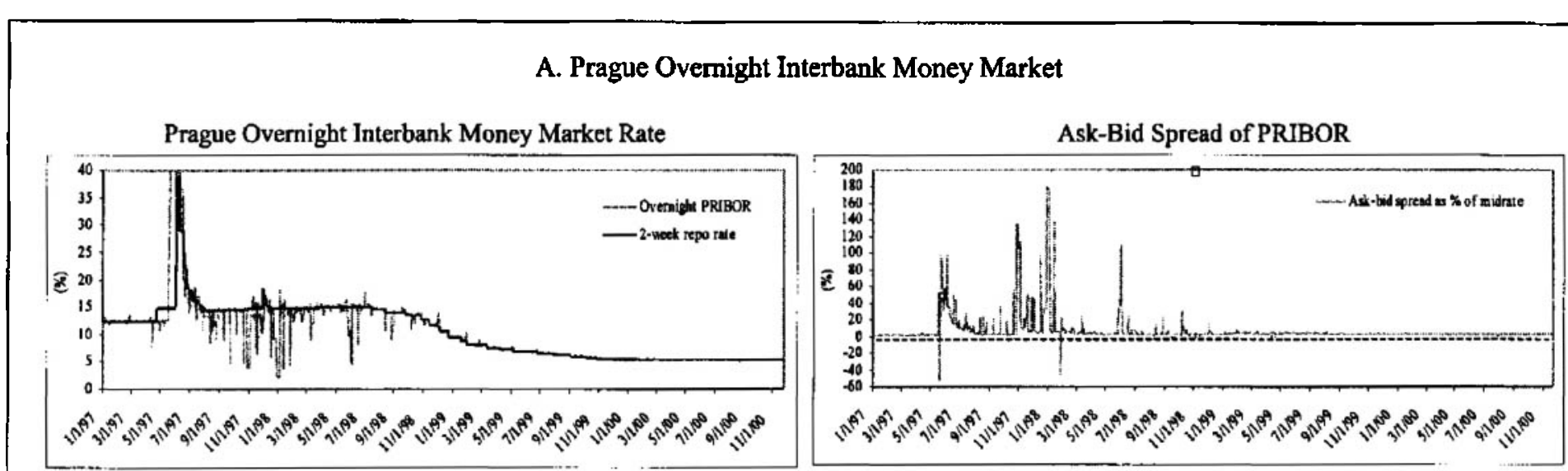

\section{B. Prague Stock Exchange}
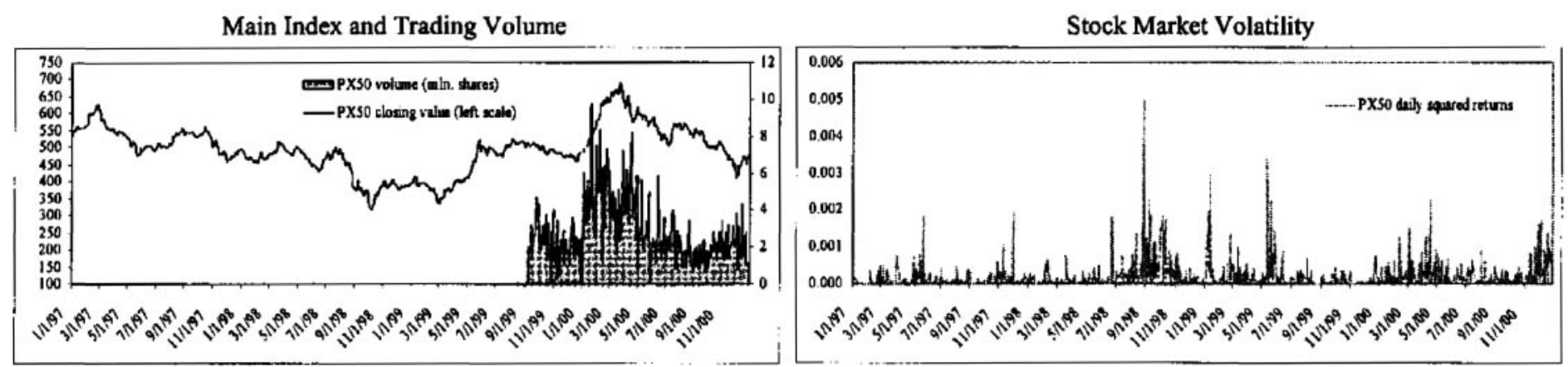

C. Foreign Exchange Market

Volatility of the Foreign Exchange Market
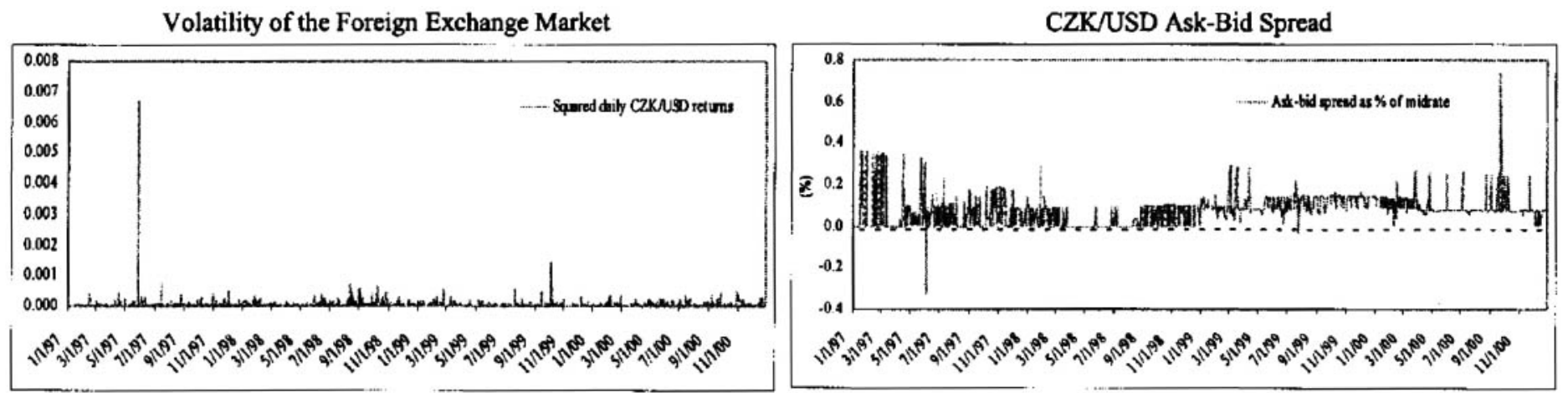

D. Secondary Government Securities Market

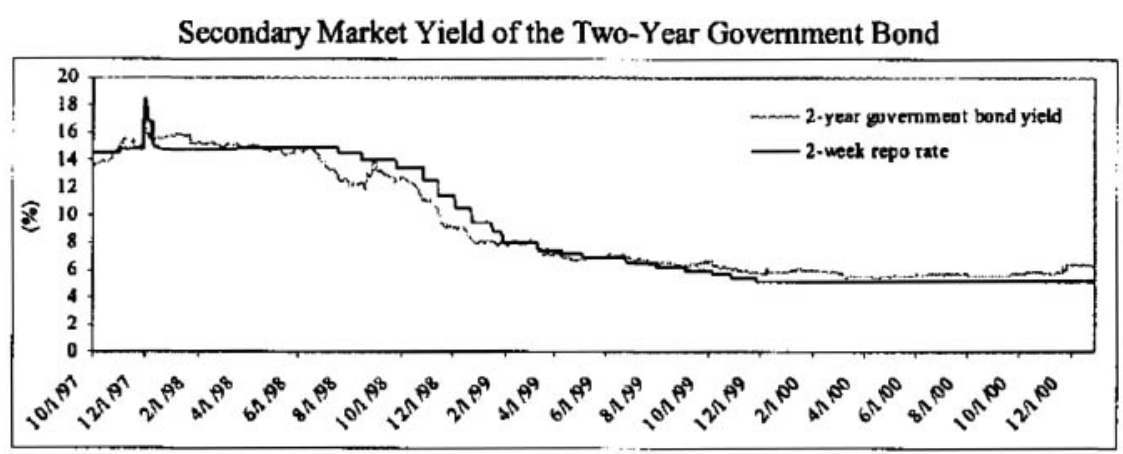

Source: Bloomberg and Staff calculations. 
29. The Czech payment system, in general, is sound. The Clearing and Settlement Center (Clearing Center) of the CNB is designed and functioning well, providing immediate intra-day finality of payment of funds transfers made within it, and thus supporting the settlement procedures of various other clearing mechanisms, in particular those in the securities markets. Participants in the clearing center (banks and the CNB) are devoting close attention to foreign exchange settlement risk, as the global procedures for settling foreign exchange transactions are revised during 2001. The clearing and settlement system itself appears free from significant vulnerabilities, and it achieves the principal purpose for which it was designed, namely, the elimination of systemic risk in the interbank payment mechanism. The main burden of credit risk management for intra-day and overnight provision of liquidity rests on the central bank. Liquidity risk is thus minimal.

\section{MACROECONOMIC Conditions}

\section{A. Macroeconomic Setting}

30. Recent economic performance suggests a sustained recovery. Following three years of negative growth, growth of real GDP in 2000 was 3.1 percent and is projected at 3.0-3.5 percent in 2001. The balance of payments position remains strong, underpinned by robust export performance and sustained FDI inflows. Financing of a widening current account deficit bas been facilitated by FDI inflows, which exceeded 9 percent of GDP in 2000 , following inflows of about 12 percent of GDP in 1999, and was only partly offset by portfolio outflows-the latter reflecting both the narrowing interest rate differentials between koruna and euro-denominated assets and ongoing portfolio rebalancing. FDI has helped the recovery by contributing to the revival of investment demand.

\section{The strong balance of payments position has resulted in episodes of upward} pressure on the exchange rate. However, the konuna has appreciated only modestly in nominal effective terms over the past year, and export competitiveness appears to have remained strong. Monetary conditions remain broadly similar to those prevailing a year ago, as a general decline in real interest rates has been offset by the moderate appreciation of the koruna in real effective terms. After remaining constant at 5.25 percent since November 1999, the CNB cut the two-week repo rate (its key policy rate) to 5 percent in February 2001.

\section{External debt is moderate ( 42.6 percent of GDP), and the country's foreign} reserve position is relatively comfortable. Total external liabilities have remained stable (as a share of GDP) in recent years, and short-term liabilities comprise a reasonable one-third of total liabilities. Currently at about 4.1 months of imports of goods and non-factor services, the Czech Republic's gross official reserves appear to provide sufficient external liquidity and a reasonable degree of protection against unforeseen external shocks. In particular, reserves cover 400 percent of the amount of maturing debt obligations in the next 12 months and 130 percent of the stock of short-term debt and cumulative inflows of portfolio investment.

33. The fiscal position has deteriorated markedly in recent years, and in the absence of fundamental reforms, fiscal pressures are expected to mount. The general government 
deficit (excluding privatization receipts and grants to transformation institutions) widened to 4.1 percent of GDP in 2000, from 3.2 percent of GDP in 1999, and is set to expand further to 5.7 percent of GDP in 2001. To this must be added the additional costs of the banking sector reform; when fully taken into account, these could reach the equivalent of 21 percent of GDP, of which about one-fourth has been realized thus far.

\section{B. Sources of Macroeconomic Risks Impacting the Financial System}

34. The restructuring of the financial and corporate sector, while incomplete, has reduced the Czech economy's overall vulnerability to macroeconomic shocks. However, it is still useful to assess the financial system's resilience to unexpected developments, whether domestic or international in origin, even if the probability of their occurrence is small. There are three key macroeconomic factors of vulnerability: (1) the sharp deterioration of the fiscal balance and the absence of well-articulated plans to address it; (2) the dependence of both the public finances and the balance of payments on large inflows of foreign direct investment, in a substantial part related to the privatization process; and (3) substantial reliance on the EU for export markets and capital.

35. The fiscal deficit represents the greatest vulnerability of the Czech economy over the medium term. A major contributing factor to the deteriorating fiscal outlook has been the accumulation of contingent liabilities of the government-mostly related to government guarantees in the banking sector-that could have a severe effect on the budget, government debt, and confidence in the koruna. So far, capital markets have absorbed new government debt without a noticeable impact on the yield curve, but this situation may well change, and the likely rise in interest rates could put a strain on the budget and the economy. In addition to a possible direct impact on the value of assets and liabilities, an interest rate increase could have an indirect impact on the quality of the loan portfolio of banks.

\section{Delays in the privatization process could result in a lower level of FDI inflows,} with consequences for the budget and the economy. Were the privatization process to stall, the exchange rate could swiftly come under downside pressures, thus forcing the CNB to raise interest rates sharply to maintain macroeconomic stability. To the extent that other FDI inflows unrelated to privatization were also to decline, for example, as a result of an unexpected delay in the EU accession process, these effects would be magnified and could threaten the sustainability of the external current account.

37. The Czech Republic is a small open economy, and external shocks could affect the economy both through financial and real channels. The recovery has relied primarily on the vibrant export sector, which has, in addition, been the sector supporting the revival of investment. Indeed, FDI has been a substitute for domestic credit and has allowed exportoriented firms (primarily the ones with foreign participation) to finance activities without being hindered by problems in the Czech banking sector. In the event of a sharp and lengthy slowdown of demand in the EU, the resultant export slowdown would have ripple effects 
through the domestic supply system, resulting in potentially substantial output losses and a deterioration in the quality of the loan portfolio of banks.

\title{
C. Monetary Policy Operations
}

38. The monetary policy framework is one of inflation targeting. In the recent period, monetary policy has been conducted in an environment of excess liquidity in the banking sector, distributed across different groups of banks. Since 1997, the relative share of quick assets in banks' portfolios has doubled to 13 percent at the end of the third quarter of 2000 , and the share of interbank deposits is relatively high at 10 percent. Changes in monetary instruments are based on inflation forecasts, in light of the inflation target, and on a comprehensive evaluation of macroeconomic and monetary developments (Figure 4). The two-week repo tender of CNB bills is the key instrument for absorbing excess liquidity and sterilizing the sustained capital inflows and has been used aggressively. Since the introduction of inflation targets in January 1998, the CNB has undershot its end-year net inflation target three years in a row. In April 2001, the CNB switched to targeting headline inflation by means of a continuous range.

39. The institutional framework, agency responsibilities and operational procedures for the conduct of monetary policy in the Czech Republic are highly transparent. The CNB is strongly accountable for its actions to the Parliament and to the public.

40. The high interest expenses associated with CNB's large repo operations have placed pressures on CNB's financial accounts in recent years. Thus, a further sharp increase in the interest expenses paid on the CNB's repo operations could translate into quasi-fiscal losses. Possible scenarios that can result in higher interest expenses include: (1) sustained capital inflows that will require rising levels of sterilization via CNB's repos; and (2) a widening of the spread between domestic and international interest rates. An appreciation could also put pressure on the profit and loss position since the CNB holds the bulk of its total assets in foreign currency denominated instruments, while almost all its liabilities are in koruna.

\section{VULNERABILITIES AND SOUNDNESS OF THE BANKING SYSTEM AND LINKAGES WITH THE CORPORATE SECTOR}

\author{
A. The Banking Sector
}

\section{Current situation}

41. After having accumulated large amounts of underperforming loans, the Czech banking system is nearing the completion of a comprehensive restructuring and privatization program. The main features of this process are: carve-out of a significant part of the large nonperforming loan portfolio and its consolidation in $\mathrm{KOB}$; the sale of the four large state banks to strategic foreign investors, and the merger of 
Figure 4. Monetary Policy Implementation

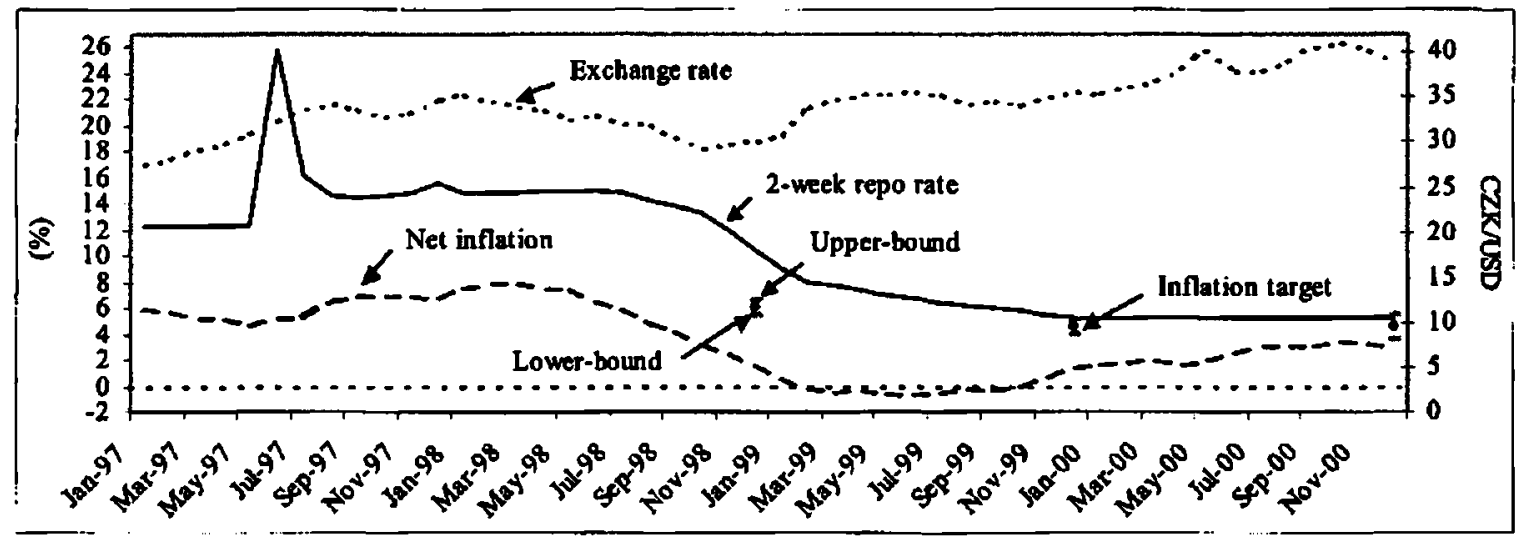

Source: CNB and Staff calculations.

Notes: The two-week repo rate is monthly average. Net inflation to the rate of change of the Consumer Price Index, excluding administered prices, the effects of changes in indirect taxes. Targets are defined for the value of the 12-month percentage change in the monthly "net Consumer Price Index" in December of the following year.

the business of two of these; and a reduction in the number of smaller banks. Reflecting in part the need to digest the new acquisitions and the lingering difficulties in part of the enterprise sector, bank managers are taking a cautious approach to credit policy; bank credit has declined slightly over the last three years in spite of the ongoing economic expansion, and is not likely to evidence rapid growth in the near future. While capital adequacy ratios appear comfortable, competition for creditworthy clients is intense, and profit margins are thin. Further consolidation may therefore be expected over the medium term.

\section{The resolution of the banking crisis has accelerated the ongoing change in the} structure of the Czech banking system. The share of banking system assets accounted for by the large banks has declined from over 80 percent in 1994 to about 60 percent now, while the share accounted for by the subsidiaries and branches of foreign banks has risen from 13 percent to over 30 percent. The number of small Czech-owned banks operating has been greatly reduced. Following the planned privatization of the last of the large banks in the near future, the Czech banking system will be about 90 percent foreign-controlled.

\section{Origin of the large stock of nonperforming loans}

43. Nonperforming loans stem from a variety of reasons. These include: inheritance of structural problems and inefficiencies from the pre-transition period; careless lending to privatized enterprises in the early 1990s; weak governance; political interference in lending decisions; weak creditors rights; and inadequate supervision. A determined effort to address all the weakness only was made in the second half of the 1990s.

\section{The earlier relatively strong growth and poor classification policies initially} masked the problem. It first became apparent among the smaller banks, several of which experienced difficulties in the mid-1990s. The 1997-99 recession and tightening of prudential policies, exposed the portfolio problems of the large banks as well. As the magnitude of the 
difficulties of the large state banks became evident, the authorities rightly adopted the strategy of privatization.

\section{Restructuring of the banks}

45. In the resolution of the banking crisis the authorities have relied on transformation agencies-KOB and its affiliates - to acquire bad loans from the banks to improve their balance sheet. For the small banks, these asset transfers were a prelude to closure as the resolution of the banking crisis among the small Czech banks resulted in the liquidation or consolidation of virtually all of those institutions that had experienced difficulties. For the larger banks the asset transfer has been in preparation for their privatization.

46. The first privatization proved to become a distinct failure. A controlling interest in IPB was sold to a foreign investor in 1998 . However, the investor treated its acquisition as a portfolio investment, selling off part of its assets and leaving the existing management and management procedures in place. The sale had not involved any balance sheet clean up, and the bank's situation continued to deteriorate although for a while the extent of this deterioration was not apparent. In June 2000, the CNB intervened, appointing a temporary administration of the bank, who immediately resold the business of the bank.

47. Subsequent privatizations appear to have been successful. Another large state bank (Československá obchodní banka-CSOB), had meanwhile been sold to a strategic foreign investor in 1999. In early 2000 a third state bank (Česká sporitelna-CS) was sold to a foreign investor. The last of the four large banks (Komerčnf banka-KB) is expected to be privatized later this year, and four strategic investors have reportedly placed bids on the bank.

48. The later privatizations have all involved carve out of non-performing loans, and have led to a sharp increase in current and prospective holdings of nonperforming loans by KOB. The holding of nonperforming loans by KOB and subsidiaries at end 2000 stood at CZK 186.6 billion (equivalent to 9.6 percent of GDP (Table 2). In addition to the outright transfer, KOB guaranteed ("ring fenced") a nominal value of CZK 25 billion of assets that remained on the books of CSOB. The total carve out associated with the recent resale of IPB is not yet fully known. It is likely that CZK 100 billion will be transferred outright to $\mathrm{KOB}$. But in addition there are uncertainties about the quality of an additional CZK 150 billion, and it is possible that some CZK 100 billion of that will be ring fenced on the books of CSOB. Finally, for KB, the authorities have announced that in addition to earlier carve-outs they will only guarantee up to CZK 20 billion. On these assumptions, the KOB

\footnotetext{
${ }^{1}$ Ceska Financni, which was established to deal with asset transfers related to the small banks, was initially set up as a subsidiary of the CNB but was transferred to the KOB group in 2000. The $\mathrm{KOB}$ subsidiary Konpo was set up to handle the transfer of bad loans from $\mathrm{KB}$ in 2000. Ceska Inkasni was set up to handle bad assets related to foreign trade in an amount of approximately CZK 27 billion; it is the only workout institution that has remained outside the KOB group.
} 
group's portfolio of nonperforming loans plus the ring fenced portfolio (for which it carries the credit risk) could increase to CZK 431.6 billion, equivalent to 21.2 percent of 2001 GDP.

Table 2. Czech Republic: Projected Loan Portfolio and Contingent Risk Exposure of KOB Group

(In billions of korunas)

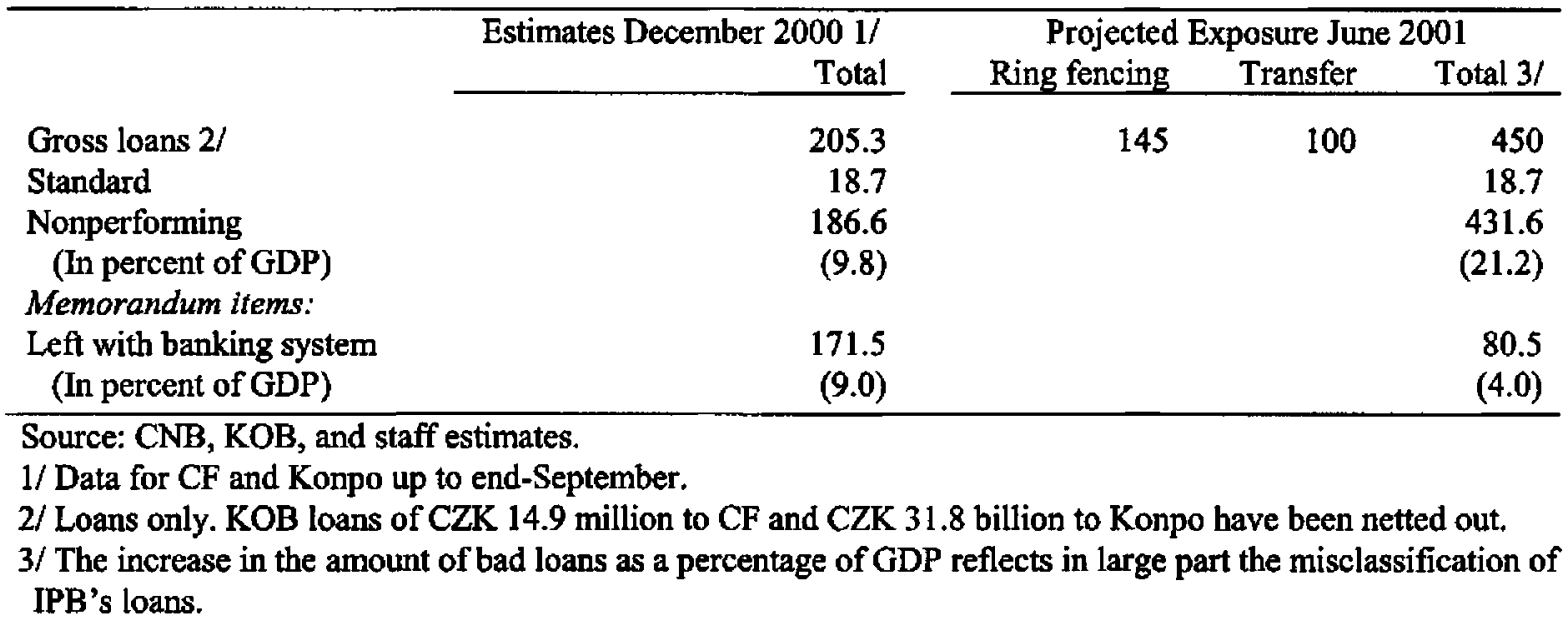

49. As a result of the above carve-outs, the remaining classified loans (categories 2 to 5) on the balance sheet of the banks will be reduced to a more manageable, but still significant level. Banks will be left with an estimated CZK 75 billion in watch loans (category 2), the equivalent of 10 percent of their loan portfolio, and with CZK 80.5 billion in nonperforming loans (NPLs) (categories 3 to 5), excluding the ring-fenced loans, the equivalent of 11 percent of their portfolio. The risk of watch loans migrating to the NPL category seems low, given the stringent classification criteria, although some risk cannot be excluded. The collateral on the NPLs amounts to CZK 68.3 billion, and provisions and reserves amount to CZK 58.9 billion. The sum of collateral, provisions and reserves seem sufficient to cover future losses associated with the NPLs. However, collateral is probably overvalued, given the problems that creditors have experienced in foreclosing on collateral.

\section{The residual vulnerability of the banking sector will be further contained by} privatization of the restructured banks to strong strategic investors. Improvements in the legal framework and the tax treatment of provisions would reduce the degree of vulnerability further. The upturn of the economy and the introduction of stronger lending policies by the new strategic investors should support a better loan performance going forward. The banking system seems well-capitalized, with an average capital to risk assets of 17 percent, and the growing presence of financially strong strategic investors. However, the importance of collateral for the coverage of loan losses indicates the need to keep improving the collateral and insolvency regimes, in order to enhance the realizable value of collateral in the banks' books. The fact that provisions are only partially tax deductible is also a matter of concern, as it provides an incentive for the banks to misclassify their loans and/or under provision them. The lack of full tax deductibility for loan write off also provides an incentive for banks to 
keep such loans on their balance sheet, and discourages loan work outs. This points to the need of introducing full tax deductibility of mandatory provisions.

\section{Cost to the government}

51. The restructuring and privatization of banks has come at a significant cost to the government. The costs already incurred have amounted to CZK 100 billion. Recent estimates indicate that the additional costs will probably be around CZK 300 billion resulting in a total cost of CZK 400 billion or 21 percent of $2000 \mathrm{GDP} .{ }^{2}$ The preliminary estimates of the MoF assume that the additional costs would amount to only CZK 200 billion. However, these estimates assume that the losses associated with the carve-outs from IPB would amount to only CZK 50 billion, an assumption is likely to prove too optimistic, given more recent information on the poor quality of IPB's assets and the very low provisions on these assets. More realistic assumptions for the final carve-outs and ring-fenced loans, combined with a reasonable recovery rate of 15 percent, would result in future losses of CZK 300 billion. Assuming the same funding costs as for the recently placed ten-year bonds, the annual interest cost to the budget would be equivalent to CZK 25 billion, or 1.3 percent of GDP.

\section{Significant challenges are facing $\mathrm{KOB}$ in recovering maximum asset value to} help reduce the ultimate cost to the budget. I this context the recent pool sale of a portfolio of nonperforming loans held by KOB was an important test case for the disposal of assets. Although the realized value at about 11 percent of the value at which it was valued on the KOB balance sheet may appear disappointing, it was to be expected given the poor quality of the loans. A continuation of the pool sales would appear to be the best way to proceed to ensure that assets are resolved in a transparent and efficient manner.

\section{Performance, stress testing, and future stability}

53. Credit risk remains the dominant vulnerability, based on the stress test results. On the basis of the potential macroeconomic vulnerabilities identified above (Section II.B.), stress tests were conducted for credit risk and market risk (interest and exchange rate changes). A shock meant to replicate the worsening of the NPL ratio that occurred during the period of the Czech recession (a 62 percent increase in nonperforming loans) produces significant negative effects on bank capital positions, with three banks falling well below the Basel minimum capital ratio of 8 percent (Table 3 ). ${ }^{3}$ This test, however, is relatively severe because the companies getting new loans are more profitable and less debt-burdened-and,

\footnotetext{
${ }^{2}$ The net cost are slightly smaller, considering the revenues from the sale of the banks which have amounted to the equivalent of about 2.5 percent of GDP.

${ }^{3}$ The base level of nonperforming loans used in the credit risk stress test calculations is adjusted downward by known or anticipated amounts of government guarantees or future asset transfers. Thus, the stress tests exclude the portfolio held by KOB. These adjustments reduce the base level of NPLs in the system by CZK 101.6 billion.
} 
therefore, more capable of withstanding an economic shock-than the borrowers that defaulted in the earlier recession.

Table 3. Czech Republic: First-Round Results of Stress Tests of Macroprudential Indicators

\begin{tabular}{|c|c|c|c|c|}
\hline Scenarios & Baseline & Credit risk & $\begin{array}{c}\text { Foreign } \\
\text { exchange risk }\end{array}$ & $\begin{array}{c}\text { Interest rate } \\
\text { risk }\end{array}$ \\
\hline & \multicolumn{4}{|c|}{ (In percent) } \\
\hline NPL/gross loans & 9.8 & 15.9 & & \\
\hline Foreign exchange rate & 37.8 & \multicolumn{3}{|c|}{44.0} \\
\hline Short-term interest rate & 5.30 & & & 6.80 \\
\hline Long-term interest rate & 7.00 & & & 8.50 \\
\hline Capital ratio (system) & \multicolumn{4}{|c|}{ (Number of banks in range indicated) } \\
\hline$>20 \%$ & 5 & 3 & 5 & 4 \\
\hline $15 \%-20 \%$ & 3 & 2 & 3 & 3 \\
\hline $10 \%-15 \%$ & 8 & 7 & 8 & 7 \\
\hline $5 \%-10 \%$ & 0 & 1 & 0 & 2 \\
\hline $0 \%-5 \%$ & 0 & 3 & 0 & 0 \\
\hline$<0 \%$ & 0 & $\mathbf{0}$ & 0 & 0 \\
\hline
\end{tabular}

Source: CNB, IMF staff.

54. At present, bank exposure to market risk does not pose a systemic problem. Stress tests show that banks can absorb both a significant upward yield curve shift (1.5 percentage points) and a sharp monetary tightening (a 4.5 percentage point increase in short-term rates). In this case, only two banks dip below a 10 percent capital ratio and none below 8 percent. It should be noted, however, that the impact on interest rates of the fiscal vulnerabilities could potentially be more severe and that they might give rise to secondary effects on the quality of the loan portfolio. For foreign exchange risk, banks across the board show negligible net exposures and are unaffected in a stress test by even large changes in exchange rates. Again, it should of course be borne in mind that such static stress tests do not take into account any secondary effect on the quality of the loan portfolio through a higher debt service burden for borrowing companies. Such an impact, however, appears, to be manageable. Analysis of the financial conditions of the corporate sector (see below) suggests that the debt of the most leveraged companies has been or is in the process of being transferred to workout institutions.

55. A consequence of the banking crisis and its resolution has been a marked change in the behavior of banks in the Czech system with regard to business lending. The crisis revealed a paucity of creditworthy borrowers among Czech companies, weak creditor rights and poor corporate governance and incentives. Foreign banks continue to lend profitably to their traditional customer base of international companies operating in the country but they remain reluctant to make commitments on commercial and industrial loans in the domestic market. They have been joined now in that reluctance by the large banks, operating under the stricter credit standards of their new ownership and management. The outcome of these changes is general stagnation in loan availabilities and intensified competition for the few good name borrowers. 
56. At the same time, deposit growth has continued, putting banks across the system into a highly liquid state. As a result, banks have acquired a large amount and wide array of low-yielding liquid assets at a time when higher yield assets are needed to hit ROE targets. Banks, therefore, are in an environment of pressure on profits. The aggregate ROA for the system-measured as operating profit before provisions, taxes, and extraordinary itemsaveraged 1.22 percent over $1995-97$ and -0.08 percent over $1998-2000$. Interest rate margins and gross earnings measures have declined as banks compete for a small pool of good borrowers, while the rate of operating costs has not seen big economies so far (Tables 4 and 5). Profitability improved in 2000 although this was overstated by the taking into profits of some provisions in connection with the transfer of loans to KOB. Adjusting for this, banks registered only minor profits.

\section{Bank managements have indicated their general reluctance to make any strong commitment at present to commercial lending until evidence of improved creditworthiness in borrowers is established, and the legal framework for debt} enforcement is improved. Recent reforms, such as the Public Auction Law, and other prospective changes that promise to improve creditor rights and collateral quality may reanimate growth of collateralized credits. However, these reforms still need to be tested (Box 1).

\section{Box 1. Debt Enforcement Vulnerabilities}

The Czech legal environment to support creditor rights and debt enforcement has been widely regarded as unsatisfactory due to insufficient laws creating clear collateral rights and an ineffective system for enforcing those rights. As mentioned before, deficiencies in the legal system have contributed to a deterioration in the quality of bank loan portfolios and, more recently, to a stifling of credit growth. Court actions against a debtor to obtain a judgment typically take from one to three years due to procedural delays, while obtaining an execution order to sell the property can take another year. Court costs are routinely high at 4 percent of the claim up to a maximum of CZK 1 million, and recoveries are low, often amounting to less than 5 percent of the nominal amount of the claim. The rights of secured creditors are limited in the kinds of collateral allowed or by requirements that make it difficult to have confidence in the collateral taken. The court process is overly complex and fraught with delay, typically taking one to two years. Secured creditors have experienced even greater difficulties seeking to enforce collateral rights in movables.

Comprehensive reforms are required to virtually all elements of the debt enforcement and credit systems to promote normalized relationships between debtors and creditors predicated on recognition and enforcement of reasonable commercial expectations. Despite the current shortcomings in the system, recent reforms and proposals promise stronger rights for creditors under the recently adopted Public Auction Law and proposals for a new law on secured transactions in moveable property. At the time of the mission, the new Public Auction Law had not been tested and was expected to face court challenge, particularly for collateral created before May 2000 .

58. Under the current conditions of excess liquidity and continued concern over the credit worthiness of enterprises, a principal vulnerability facing the Czech system is that banks may take risks in nontraditional business lines in order to generate higher returns. Many banks have expressed their interest in pursuing the retail banking marketcredit cards, consumer loans, household mortgages. While these kinds of loans have a track record of superior performance compared to business loans, vigilance is required to avoid that intense competition in these rather limited markets may lead to a slippage of credit standards. 
Table 4. Czech Republic: Profitability Indicators of Czech Banks

(In percent)

\begin{tabular}{|c|c|c|c|c|c|c|c|}
\hline & \multirow[t]{2}{*}{1997} & \multirow[t]{2}{*}{1998} & \multirow[t]{2}{*}{1999} & \multicolumn{4}{|c|}{2000} \\
\hline & & & & Mar. & June & Sep. & Nov. \\
\hline Interest rate spread/assets & 3.76 & 3.52 & 2.63 & 2.40 & 2.44 & 2.54 & \\
\hline Profits from banking activities/assets & 4.55 & 4.53 & 3.90 & 3.43 & 3.30 & 3.31 & $\ldots$ \\
\hline Operating expenses/assets & 2.21 & 2.25 & 2.21 & 1.96 & 2.12 & 2.11 & $\ldots$ \\
\hline Rate on new credits (short-term) & 15.91 & 11.64 & 6.74 & 6.89 & 6.85 & 6.54 & 6.41 \\
\hline Rate on deposits (short-term) & 11.20 & 9.16 & 4.82 & 4.56 & 4.37 & 4.26 & 4.09 \\
\hline Spread: new credits - deposits & 4.71 & 2.48 & 1.92 & 2.33 & 2.48 & 2.28 & 2.32 \\
\hline
\end{tabular}

Sources: CNB and staff calculations.

\section{Banking supervisory vulnerabilities}

59. Czech banking supervision has improved in recent years although vulnerabilities remain. In preparation for EU accession, the legal framework covering the regulation of the banking sector is being gradually harmonized with $\mathrm{EU}$ minimum standards and international best practice. Overall, the CNB was found compliant/largely compliant with 20 of the 25 Basel Core Principles. A recent amendment to the Act of Banks, that would have, inter alia, extended the scope of consolidated supervision, was rejected by parliament but is expected to be re-submitted during 2001. Amendments to the Bankruptcy Act and the enactment of a new Public Auction Law have strengthened the rights of banks in the enforcement of security. However, the operation of the courts remains slow and the banks continue to report a lack of willingness on the part of court officials to support creditor action. Further legislative and judicial reform in this area is essential.

60. The quality of supervisory staff has improved although current skills amongst the supervisors to assess market risk, audit computer-based systems and evaluate risk management systems remain low. Moreover, heavy staff turnover, particularly among the inspection teams, has led to resource pressures within the $\mathrm{CNB}$, both in terms of staff numbers and experience levels. Remaining weaknesses include:

- banks not yet required to allocate capital to cover market risk on a consolidated basis;

- consolidated supervision yet to be extended to nonbank financial holding companies or mixed holding companies;

- insufficient attention provided to corporate governance and internal control functions;

- a lack of clarity with respect to the role and responsibilities shared by the CNB (banking supervision), the MoF (insurance supervision), and the CSC (securities supervision) for the supervision of firms operating in all three financial sectors; and

- $\quad$ although anti-money laundering is covered by separate legislation, key reporting requirements should also be set out explicitly in CNB banking regulations. 
Table 5. Macroprudential Indicators

(In percent; year-end data)

\begin{tabular}{|c|c|c|c|c|c|c|}
\hline & & 1996 & 1997 & 1998 & 1999 & 2000 \\
\hline \multicolumn{7}{|l|}{ CAPITAL ADEQUACY } \\
\hline Tier-1 capital / risk-weighted as & sets & 9.23 & 8.56 & 9.46 & 10.85 & 13.71 \\
\hline Total capital / risk-weighted ass & & 9.95 & 9.49 & 12.06 & 13.64 & 17.23 (Nov) \\
\hline Total capital / total assets & & 5.68 & 5.10 & 5.70 & 5.77 & 5.07 (Nov) \\
\hline \multicolumn{7}{|l|}{ ASSETS } \\
\hline Share of loans (exposures) & $\mathrm{RW}=0 \%$ & 23.2 & 25.1 & 32.0 & 35.1 & 39.9 \\
\hline \multirow[t]{3}{*}{ per risk weight (RW) category: } & $\mathrm{RW}=20 \%$ & 22.5 & 24.9 & 23.1 & 23.9 & 25.5 \\
\hline & $\mathrm{RW}=50 \%$ & 1.5 & 1.8 & 2.0 & 1.9 & 2.5 \\
\hline & $\mathrm{RW}=100 \%$ & 52.8 & 48.2 & 42.9 & 39.1 & 32.2 \\
\hline Total exposures/ Total assets & & 105.9 & 106.2 & 106.5 & 106.8 & 110.6 \\
\hline \multicolumn{7}{|c|}{ Loan (or exposure) concentration } \\
\hline \multicolumn{7}{|l|}{ Sectoral concentration: } \\
\hline individuals & & $\ldots$ & 5.12 & 6.41 & 8.47 & 10.75 (Nov) \\
\hline government & & $\ldots$ & 0.87 & 1.28 & 1.27 & 1.44 (Nov) \\
\hline agricultural sector & & $\ldots$ & 2.32 & 2.35 & 2.31 & 2.17 (Nov) \\
\hline mining & & $\ldots$ & 2.00 & 1.81 & 1.70 & 1.46 (Nov) \\
\hline manufacturing & & $\ldots$ & 30.36 & 28.68 & 25.76 & 24.39 (Nov) \\
\hline transportation & & $\cdots$ & 3.12 & 2.58 & 2.50 & 2.79 (Nov) \\
\hline financial services & & $\ldots$ & 6.47 & 7.31 & 6.90 & 7.51 (Nov) \\
\hline other services & & $\ldots$ & 49.74 & 49.57 & 51.08 & 49.49 (Nov) \\
\hline \multicolumn{7}{|l|}{ Foreign currency lending } \\
\hline Foreign exchange loans / total lo & tans & 18.8 & 24.8 & 25.1 & 26.0 & 25.2 \\
\hline \multicolumn{7}{|c|}{ Nonperforming loans (or exposures) } \\
\hline NPLs / total gross loans (or expc & osures) & 21.6 & 20.5 & 20.3 & 21.5 & 19.5 \\
\hline NPLs net of provisions / total ca & pital & 104.1 & 99.0 & 72.8 & 71.1 & 60.2 \\
\hline \multicolumn{7}{|l|}{ MANAGEMENT } \\
\hline Expenses/revenues & & 80.6 & 79.5 & 82.9 & 83.0 & 70.4 (Nov) \\
\hline Earnings/employee (in thousand & $s$ of korunas) & 1,300 & 1,702 & 1,865 & 1,845 & 1,725 \\
\hline \multicolumn{7}{|l|}{ EARNINGS } \\
\hline Return on (average) assets & & $\ldots$ & -0.02 & -0.20 & -0.20 & $1.57(\mathrm{Dec})$ \\
\hline Return on (average) equity & & $\ldots$ & -0.25 & -3.30 & -3.48 & 10.23 (Dec) \\
\hline Interest margin / gross income & & 47.9 & 45.8 & 73.0 & 58.2 & $66.9(\mathrm{Dec})$ \\
\hline Noninterest expenses / gross inc & ome & 80.7 & 68.6 & 92.8 & 107.9 & $99.6(\mathrm{Dec})$ \\
\hline \multicolumn{7}{|l|}{ LIQUIDITY } \\
\hline Liquid assets / total assets & & 16.2 & 17.0 & 23.1 & 26.4 & $26.8(\mathrm{Dec})$ \\
\hline Liquid assets / short-term liabilit & & $\ldots$ & $\ldots$ & 54.9 & 63.9 & 62.1 \\
\hline
\end{tabular}

Source: CNB

61. With the large inflow of foreign investment into the Czech banking sector, $a$ number of banks have imported credit systems from their parent operations. While this will encourage an improvement in the practice of credit management, there remains a lack of a formal requirement for banks to set out their policies, practices and procedures relating to the credit process. The predominant foreign control of the Czech banking system highlights 
the urgent need for strengthened supervision of foreign banks' establishments. Most importantly, it will require an efficient system of information sharing and formal Memoranda of Understanding (MOUs) with supervisory counterparts. So far, only a few MOUs have been signed.

\section{Safety net arrangements}

62. The Czech deposit insurance scheme, which is operated by the Deposit Insurance Fund (DIF), was introduced in 1994. Although nominally limited to CZK 400,000, of the 10 banks that have failed during the life of the DIF, depositors of seven banks received a full reimbursement of their funds up to a maximum value of CZK 4 million. An amendment to the Act on Banks which is currently under consideration would require the DIF to equalize the position for depositors of the remaining three failed banks by also offering a compensation up to CZK 4 million. The decision to reimburse depositors in excess of the notional deposit guarantee ceiling was taken to ensure the stability of the banking sector as a whole. However, it is likely to have created an expectation among depositors that their deposits will be fully guaranteed by the authorities in the event of any future bank failures. This raises the threat of moral hazard and potentially reduces the motivation for banks and depositors to exercise discipline in terms of risk-based decision making.

\section{More generally the capacity of the DIF carry out its narrow "pay box" role} remains limited. DIF reserves, which have been drained as a result of previous pay outs, are equivalent to less than 1 percent of the total of insured deposits. This would be insufficient to deal with a failure of a medium- or large-sized bank or a number of small bank failures. Furthermore, proposals to raise the ceiling on deposit insurance to $€ 25,000$ and to broaden the coverage to include foreign currency deposits, while at the same time reducing the percentage of insured deposits that the banks are required to pay to the DIF, will further limit the DIF's ability to meet any obligations that may arise in the short-term.

\section{Although previously the DIF has been able to rely on automatic access to} funding from the government and the $\mathrm{CNB}$, proposals now being considered by parliament would remove the obligation of the authorities to lend to the DIF. Instead, the DIF would be required to seek market funding. The appetite in the market for DIF-issued debt remains untested. The changes in the funding structure will present new challenges for the DIF. It will require the DIF to anticipate more precisely future demands on its reserves so that it can discharge its payout function on a timely basis. Greater effort is also required to better inform the public of its roles and responsibilities and improve operating systems relating to setting and collecting premiums.

\section{B. Corporate Sector and the Financial System}

65. The financial performance of the corporate sector was disappointing during the second half of the 1990s, especially in the case of the manufacturing sector (Table 6), but there are indications that the situation improved somewhat in 2000 . The 
disappointing financial performance of the corporate sector in this period is to some extent related to the slowdown in economic activity, but more important structural causes included the poor governance structures resulting from the voucher privatization program, and the lack of creditor discipline. While the nascent improvement in 2000 reflect in part the strengthening macroeconomic picture, it may also reflect the ongoing reform efforts.

Table 6. Czech Republic: Enterprise Profits and Losses, 1995-99 (In percentage of GDP)

\begin{tabular}{llll}
\hline & 1995 & 1997 & 1999 \\
\hline Gross Profits & & & \\
Industry & 7.5 & 4.8 & 6.2 \\
$\quad$ Manufacturing & 4.2 & 3.3 & 2.2 \\
Gross Losses & & & \\
Industry & 2.0 & 2.2 & 3.2 \\
Manufacturing & 1.8 & 1.9 & 2.2 \\
\hline
\end{tabular}

Source: Central Statistical Office (CSO)

66. Despite the signs of improvement in 2000, there is a large segment of the corporate sector which continues to generate losses and is highly leveraged. The average debt-equity ratios in the corporate sector are not excessive-roughly 100 percent for industry and 135 percent for manufacturing (Table 7). In comparison, the average debt-equity ratios in Korea and Thailand before crisis were 450 and 200 percent, respectively. However, the debtequity ratios for the group of loss-making enterprises are twice as high, and the debt-equity ratios for enterprises classified as doubtful or loss (the two lowest categories) are extremely high, exceeding 700 percent for a sample of manufacturing enterprises. Moreover, the debtequity ratios for the weak performers probably underestimate their true leverage, since the market values of their equity tends to be a fraction of book values. ${ }^{4}$ Until these problem enterprises are successfully resolved, the pool of creditworthy enterprises will continue to be limited.

67. There may be a segment of medium and small enterprises which are profitmaking and not excessively leveraged, but are being deprived from credits due to the weak legal framework. Although medium and small enterprises tend in general to have higher debt-equity ratios, the average ratio of medium-sized, profit-making enterprises does not seem excessive-100 percent for industry. However, the traumatic experience with nonperforming loans and the difficulties that banks have experienced in the past to foreclose on collateral and pursue their claims under bankruptcy has contributed a stagnation in lending activities, and it is likely that enterprises which would be acceptable risks under well functioning collateral and bankruptcy regimes have also been deprived from credits. The new

${ }^{4}$ The average debt-equity ratios for groups of enterprises classified as standard and loss were obtained by cross-checking information from the Central Statistical Office with data from commercial banks. 
Law on Public Auctions has been, in this regard, a very positive step in the right direction, but it has not been tested in practice. The authorities should monitor closely the implementation of this law, and take steps to improve the collateral regime further.

Table 7. Czech Republic: Debt-Equity Ratios in Different Segments of the Corporate Sector, 1999

(In percent)

\begin{tabular}{|c|c|c|c|c|c|c|c|c|c|}
\hline \multicolumn{2}{|c|}{ All Enterprises } & \multicolumn{2}{|c|}{ Profit Makers } & \multicolumn{2}{|c|}{ Loss Makers } & \multicolumn{2}{|c|}{$\begin{array}{c}\text { Classified as } \\
\text { Standard }\end{array}$} & \multicolumn{2}{|c|}{$\begin{array}{c}\text { Classified as } \\
\text { Doubtful/Loss }\end{array}$} \\
\hline Industry & Manuf. & Industry & Manuf. & Industry & Manuf. & Industry & Manuf. & Industry & Manuf. \\
\hline$(5,019)$ & $(1,711)$ & $(3,517)$ & $(1,178)$ & $(1,502)$ & (533) & $(1,434)$ & (486) & (63) & (25) \\
\hline 94.4 & 135.5 & 80.7 & 101.3 & 147.7 & 227.2 & $69.6^{\prime}$ & 116.2 & 660.8 & 764.8 \\
\hline
\end{tabular}

Sources: CSO, CNB

Note: Number of sampled enterprises in parentheses.

68. The voucher privatization program and the weak regulatory framework resulted in poor corporate governance structures, which explain in good part the poor financial performance of Czech enterprises during the 1990s. Both internal and external mechanisms of corporate governance proved to be weak. The lack of accountability of management and major shareholders, and the lack of monitoring of their actions by other stakeholders, contributed throughout the 1990s to poor investment decisions, and the transfer of value out of companies to insiders and parties related to insiders. It also contributed to a loss of confidence of the Czech population in capital market institutions that will take time to be restored. Foreign investors have been deterred from expanded portfolio investment or from direct investment except when a controlling stake is available.

69. The Czech authorities have recognized the costs Imposed by poor corporate governance on the economy and the need to improve governance practices to avoid a recurrence of structural problems. A further factor impelling corporate governance reforms has been the requirement to harmonize capital markets and financial reporting rules with EU directives. Substantive changes have accordingly been made to a number of key laws over recent years, including a major package of reforms during 2000. The legal responsibilities of corporate insiders have been clarified and expanded, minority shareholder rights have been strengthened, a takeover regime has been adopted, and accounting and auditing standards have been improved. An independent securities commission was established in 1998, and its powers have been expanded. Finally, voluntary codes of corporate governance based on international best practices, bave been promoted by the Institute of Directors and the CSC.

70. Well-defined creditor rights are an important component of the corporate governance architecture, and this component needs to be improved further. Creditor 
rights under bankruptcy remain weak, despite the amendments to the Bankruptcy Law that were introduced in May 2000. Corporate governance rules for financial institutions also need to be improved further. Financial institutions are special corporations and need more specific rules than those applied to ordinary publicly tradable companies, particularly in the areas of internal controls and risk management.

71. While the regulatory framework affecting corporate governance has been substantially upgraded, enforcement remains unsatisfactory. Enforcement of the regulatory framework depends on the actions of supervisory agencies, SROs, as well as the efficiency of the court system. Supervisory capacity in capital markets, banking and insurance needs improvement. SROs need to be more proactive in exercising their supervisory powers. As one example, the Chamber of Auditors has not been sufficiently proactive in monitoring the performance of its members.

72. The impact of the new corporate governance architecture will remain limited while the court system continues to fail in serving as the ultimate interpreter and enforcer of corporate governance standards. The courts suffer from a lack of resources and wider experience among the judges in understanding modem business laws and of corporate finance (a problem that will be exacerbated by the increasing sophistication of Czech laws relating to the financial and corporate sectors), and from a costly and cumbersome court process. Though court reform is a subject of much broader significance than the corporate governance system, it remains a fundamental constraint on the development of a credible and internationally compliant system of corporate governance in the Czech Republic.

\section{VULneRabILITIES AND SOUNDNESS OF THE NONBANK FinanCIal SySTEM}

\section{Since 1998, an intensive effort has been undertaken to improve regulation and} supervision of all nonbank financial efforts. Any remaining shortcomings do not introduce any systemic vulnerabilities at this stage.

\section{A. Securities Markets and Collective Investment Institutions}

74. Since 1998, there has been strong efforts to improve regulation and supervision of capital market activities, reduce market fragmentation, and eliminate weak institutions. A new CSC was created in 1998. The regulatory framework has been improved in several steps. An impressive package of amendments and new laws become effective on January 1,2001. Market fragmentation was substantially reduced by the obligation for all PSE members to report all trades to the PSE system, including off-exchange trades. Finally, the number of institutions allowed to operate was dramatically reduced, through the re-licensing of brokerage firms, the de-listing of companies from the PSE, and the mandatory opening of closed-end mutual funds. These reforms have improved dramatically the average financial standing of licensed institutions, enhanced transparency, and reduced unfair trading 
practices. However, confidence is only slowly being restored, and it may take a while for the equity market to become a source of finance for the corporate sector. Overall, of the 30 IOSCO Core Principles, 19 were implemented and 10 were partially implemented.

75. The mutual fund sector is undergoing a dramatic consolidation, due to the mandatory opening of closed-end funds and to other improvements in regulation and supervision. The regulatory framework for collective investment institutions has been significantly improved in recent years and is generally adequate. The ongoing consolidation is primarily due to the mandatory opening, the liquidation of illiquid funds, and the exit of weak AMCs. The share of open funds in total assets probably exceeds 90 percent, and the largest AMCs now belong to prominent local and multinational financial groups. There are more than $\mathbf{5 0}$ funds under liquidation, but these account for a small share of total assets. The consolidation of the sector has been generally a positive development, although the concentration in the sector is very high, with the three largest management companies controlling 81 percent of total net assets.

76. The CSC needs to acquire more regulatory independence and further resources to be able to effectively discharge its broader responsibilities. The CSC is excessively limited in its capacity to issue regulation, as the MoF has remained responsible for basic policy formulation, the submission of new legislation to Parliament, and also for the enactment of secondary legislation. The CSC has also faced severe resource limitations to build experience and technical expertise in key areas, such as auditing and risk management. That has frequently resulted in a formalistic supervisory approach, that focuses on ensuring compliance with formal obligations, instead of a more focused and effective risk-based approach.

77. The CSC is to be commended for its achievements in the last three years, However, it is still a young institution, and has lacked the resources to hire, retain, and train experienced professionals. Supervisors are generally inexperienced and lack skills in key areas, such as accounting, auditing, and risk management. This problem is ultimately reflected in the CSC's supervisory practices.

\section{B. Insurance Sector}

78. The insurance sector is growing and performing generally well, with adequate levels of capital and profitability. Total assets of insurance companies in 1999 amounted to 8.5 percent of GDP in 1999, and have been invested conservatively. Solvency requirements follow the formula used in the EU, and in 1999 most companies had solvency margins that exceeded minimum requirements by a comfortable margin. The levels of profitability are adequate, due in good part to the low ratios of claims over premiums. However, the ratio of expenses to premiums looks high suggesting the existence of inefficiencies.

79. The regulatory system has been substantially improved through a new Insurance Law that became effective in April 2000. The new law represents a major step towards 
harmonization with the EU. Despite these improvements, the regulatory framework for the insurance sector still contains some weaknesses, primarily in the areas of licensing, corporate governance, and external auditing. Overall, of the 17 Insurance Core Principles, 8 were observed or largely observed.

80. Supervision of insurance companies is conducted by the Office of Supervision inside the MoF. Currently, the Office is understaffed, supervisors are not adequately trained in modern techniques of supervision by risk, and have not conducted frequent on-site inspections. The Office has plans to prepare itself for the implementation of the EU approach to supervision, and has proposed important increases in staff size and is moving to develop new supervisory procedures, with assistance from a resident advisor from the German supervisory authority. Given the growing importance of the insurance sector, interconnectedness in the financial sector, and the need for practicing modern supervisory policies, serious consideration should be given to establishing an independent and publicly accountable insurance regulatory and supervisory agency.

\section{Pension Funds}

81. An effectively implemented consolidation process has reduced the number of pension funds and increased their financial standing. There is increasing participation of several large multinational financial institutions from European countries. Market concentration is high, with the three largest funds accounting for 65 percent of assets. Total assets have grown slowly due primarily to low average contributions. Return on assets has been moderate, as the majority of funds have favored relatively low-yielding government bonds and bank bonds. This has been partly due to the short time horizon of asset managers, that resulted from a low cut-off age and the possibility of participants to enter short contracts. However, the growing focus of pension funds on retirement saving suggests that they will gradually favor more balanced portfolios and expand their holdings of domestic and foreign equities. Operating costs have been dominated by marketing expenses but have not been excessively high.

82. Regulation has been substantially strengthened in recent years, but there are still some important weaknesses. The supervision function needs to be upgraded, including the efficiency of routine off-site surveillance and on-site inspection of pension funds remains a pressing issue and a challenge. The CSC will have to prepare itself to meet this challenge, as proposed amendments to the Securities Commission Act include the full shift of supervisory responsibilities from the MoF to the CSC in January 2002.

\section{Other Nonbank Financial Institutions}

\section{Credit unions}

83. The credit unions are not systemically important. Although losses due to poor lending controls and fraud have been significant in relation to the size of the credit union 
sector as a whole, there is nothing to indicate any contagion to the rest of the financial sector. Although the legislation covering credit unions was amended in May 2000 giving the regulator, the CUSA, increased powers, the problems that emerged as a result of the original weaknesses in supervision continue to adversely affect the sector. On the basis of current estimates credit union members have lost as much as 90 percent of their aggregate deposits.

84. In the short run, the problem facing the CUSA and the MoF relates to the claims resting with the Credit Union Insurance Fund, and the resolution of the credit unions that are under conservatorship. In addition, a licensing, regulatory framework needs to be put in place that will permit only the financial and managerially sound credit unions to function. However, the continuing viability of the credit union sector remains unclear. Competition from banks, after their restructuring phase is completed, will pose asset side pressures on the credit unions. The challenge will be to ensure that credit unions make prudent investment and lending decisions within a revamped regulatory framework. Consideration also needs to be given to bring the regulation and supervision of all types of deposit-taking financial institutions under a unified supervisory framework.

\section{Leasing companies}

85. In the absence of significant amounts of bank credits being made available to the SME sector, leasing has emerged as an important intermediator for small- and mediumsized enterprises. This development also reflects the weak legal environment to support creditor rights and debt enforcement. During the 1990s there has been a sharp growth in the size of the Czech leasing industry. As of January 2000 there were 122 leasing companies that were members of the Czech Association of Leasing Companies (CALC). The CALC accounts for 95 percent of the domestic leasing market. Most leasing business is undertaken by bank subsidiaries or captive companies of the major automobile companies.

86. Between 1995 and 1999 the value of new leasing contracts written during the year increased from CZK 29 billion to CZK 81 billion. The total value of outstanding leasing contracts had reached around CZK 150 billion at end-1999, or about 5 percent of total bank assets. This level of business is high by regional standards. The value of new contracts written in 1999 accounted for more than 1.5 percent of the European volume, with the Czech Republic ranked twelfth among European countries by volume. There is no regulatory oversight of the leasing sector, other than of bank subsidiaries that has yet to be fully integrated within the consolidated supervision framework of the CNB.

\section{ENSURING Stability: SUMmaRy OF Key ReCOMMENDED ACTIONS TO ADDRESS VULNERABILITIES}

87. The key macroeconomic vulnerability facing the Czech Republic stems from the unsustainability of fiscal policy. This issue is discussed in more detail in the staff report on the Article IV consultation. 
88. Key issues in completing the transformation of banks and enterprises are:

- Finalization of the carve-out of nonperforming loans arising from the recent resale of IBP and the completion of the sale of KB;

- Acceleration of the pool sales of bad loans initiated by the KOB group in early 2001 .

- Enhancing efforts to improve the collateral and insolvency regimes to expedite enterprise restructuring and bank work-outs, and improve the auction price of nonperforming loans.

- Introduction of full tax deductibility of mandatory provisions.

89. The CNB, the MoF, and the CSC should strengthen, as a matter of priority, the systems for risk identification and risk monitoring across each financial group as well as the mechanisms for coordinating supervisory action wherever necessary. The agencies should consider setting up a regulatory committee (collegium) that would meet on a regular basis to consider the underlying risk issues in each financial group, licensed entities, and developments in each sector.

90. In the area of banking supervision, the key issues are:

- a need to move more swiftly toward a risk-based approach to supervision, targeting resources on the key risks facing the banks on both a sector and individual bank basis;

- application of capital charges on a consolidated basis for other risks (currently credit risk only) and the introduction of consolidated supervision for financial holding companies and mixed holding companies;

- regulations need to be made more specific with respect to some of the credit risk governance aspects including a bank board approved loan and investment policy;

- requirements for risk management processes need to be set out explicitly in the regulations;

- anti-money laundering procedures need to be made more explicit in CNB regulations; and

- $\quad$ supervisory skills and resources to assess market risk, audit computer based systems, and evaluate risk management systems could be further strengthened.

91. The safety net system needs strengthening. In this context:

- the authorities should consider a public restatement of the role of the DIF in the financial system and strengthen its public credibility; 
- the DIF needs to consider its own funding arrangements, given the expected removal of the obligation of the authorities to cover any shortfall in the Fund's reserves; and

- the DIF also needs to engage in regular dialogue with banking supervisors and to monitor closely any adverse developments in relation to individual institutions that might represent a future obligation on its reserves.

92. While the authorities have begun taking steps to strengthen oversight of the credit union sector, there are a number of additional measures which merit consideration.

- Credit union membership in the Czech Republic should be limited to a "common bond" (e.g., memberships to be contained within a specific geographic area or work place).

- The CUSA should have rule-making powers and should be made independent of the MoF. At a prudential level, the CUSA should have direct responsibility for stipulating minimum solvency "large exposures" and liquidity requirements.

- Given its limited resources the CUSA should also move to risk-based supervision, targeting resources to the higher impact more complex unions, and its supervisory capacity also requires immediate attention and strengthened.

93. In the area of securities regulations and supervision the CSC must complete the main structural reforms initiated in 1998. Major issues include:

- Regulatory independence and supervisory capacity should be enhanced through a fundamental change in approach, from formal monitoring of compliance to a more proactive, focused and risk-based supervisory approach. The strengthening of the supervisory function will also require a more efficient use of SROs, which will allow the CSC to concentrate its resources more effectively.

- The bar for listing requirements should be lifted and higher standards for client/broker relationships established.

- Risk-based liquid asset requirements for investment service companies should be introduced.

- Transparency of securities regulation relating to investor rights protection should be explicitly specified in relevant legislation and disclosed through the CSC's publications.

94. For the mutual funds sector, the authorities must complete the harmonization with EU legislation. The main actions include: 
- Mutual funds should publish detailed data on the composition of their portfolios, risk exposures should be disclosed more adequately, the maximum limit on holdings of individual equities should be reduced from 10 to 5 percent of net assets, forward pricing should be introduced, assets valuation by depositories should be enhanced, and independent valuations of illiquid assets should be introduced.

- The role of depositary institutions should be strengthened and their legal responsibilities should be better enforced.

95. The regulatory framework in the insurance sector has been recently upgraded, but the authorities may consider further improvements in several areas.

- The authorities should consider creating an autonomous supervisory agency.

- Licensing criteria should be strengthened further by introducing formal conditions on the financial strength of shareholders.

- Corporate governance rules should be strengthened, by imposing on the Boards special responsibilities for the protection of policyholders.

- The appointment of auditors should be subject to approval by the supervisor, and the supervisors should be notified of any change in the appointment of auditors.

- On-site inspections should be enhanced, which will require the upgrading of expertise and professional skills.

- Transparency practices relating to insurance regulation also require strengthening.

96. Regulation and supervision of pension funds should be enhanced by:

- $\quad$ adopting the mutual fund model for pension funds as soon as possible;

- requiring a minimum pension fund size for offering annuities directly, subject annuity products to actuarial review, and introduce mandatory reserves proportional to the size of assets under management;

- guaranteeing that returns should be abolished or subject to solvency reserves; and

- transfering the supervision over pension funds to the CSC in January 2002, as proposed. However, the CSC will need to obtain the resources and skills to meet this challenge successfully. 
97. In order to assist in the development of financial markets, the following should be considered:

- $\quad$ setting and enforcing limits on primary dealers maximum ownership of a particular issue bought directly or indirectly; and

- considering allowing primary dealers in from abroad with remote access to increase competition in the market beyond local market participants.

98. Despite strengthening of the corporate governance architecture, key areas that may require further improvements include the following.

- $\quad$ strengthening requirements for the disclosure by insiders of interests in transactions and for shareholder approval;

- ensuring further harmonization with international accounting standards, in conjunction with the business community and accounting and auditing representatives;

- $\quad$ strengthening the independence of external auditors;

- $\quad$ strengthening creditor rights by improving further the collateral and insolvency regimes; and

- $\quad$ strengthening the capacity of the courts to provide effective and prompt resolution of civil and criminal litigation, concerning the responsibilities of companies, directors, managers, and auditors. 


\section{Part II. Financial Sector ROSC Modules (FSRMs)}

This part contains the summary assessments - Financial Sector ROSC Modules (FSRMs) - of the standards assessed in the context of Czech Republic's stability assessment. The Czech Republic's observance with six key international standards was carried out as part of the FSAP work. These included (1) the IMF's Code of Good Practices on Transparency in Monetary and Financial Polices (MFP Transparency Code); (2) Basel Core Principles for Effective Banking Supervision (BCP); (3) IAIS Core Principles for Insurance Supervision (ICP); (4) IOSCO Objectives and Principles of Securities Regulation (SCP); (5) Committee on Payment and Settlement System Core Principles for Systemically Important Payment Systems (CPSIPS); and (6) OECD Principles of Corporate Governance (OCG). The assessment provided input in formulating the overall assessment of financial system stability in the macroeconomic context, identify areas for improvement, and develop a corrective action plan in areas of non-observance requiring immediate follow up.

The assessments have been prepared by Udaibir S. Das and Plamen Yossifov (IMF) on the MFP Transparency Code; Antonio J.V. Aguas (Bank de Portugal), Andy Beadle (Financial Services Authority, United Kingdom), and Udaibir S. Das (IMF) on BCP; Andrew Proctor (Hong Kong Securities and Futures Commission) and Jeppe Ladekarl (World Bank) on the SCP; Donald McIsaac (World Bank) on ICP; James Dingle (Bank of Canada) on CPSIPS; and Douglas Webb (World Bank) on OCG.

The assessments were carried out on the basis of the information provided by the Czech authorities, discussions with relevant officials, and research done by the mission. The assessment of the regulatory and supervisory framework relating to the banking and securities sectors was based on the self assessments completed by the CNB and the CSC. Meetings were held with selected banks, insurance companies, pension funds, and investment and securities companies, and the auditing, accountants', and bankers' associations. The mission's assessment was also based on the analysis of various relevant statutes and regulations as well as responses to FSAP questionnaires. It also drew upon the work previously done by the World Bank in the areas of enterprise restructuring, insolvency regimes, and capital markets.

Significant progress has been made in the legislative and regulatory framework aimed toward harmonization with EU standards. There are, however, areas where further improvement is necessary to reduce vulnerabilities and strengthen the framework within which the financial system operates. In particular, capacity constraints and administrative and judicial processes were proving to be major constraints toward the full implementation of supervisory practices in a rapidly changing financial system.

The payment and settlement infrastructure is broadly in place to support transparent and reliable money and capital market operations. Further improvements are required in improving corporate govemance, accountability, and market discipline, as well as promoting the more efficient exit of companies and banks.

A high level of observance was assessed with respect to transparency practices relating to monetary policy. However, transparency relating to the institutional relationship between monetary and fiscal operations carries several gaps and assumes importance during a period of financial and corporate restructuring. Steps in the direction of enhanced consultation with the market participants when substantive technical changes are made in the structure of monetary regulations and monetary policy operations would help improve governance and accountability. As regards financial policies, while good practices in transparency in banking supervisory policies were in place, transparency practices relating to insurance, securities, and payment system policies need further strengthening. 


\section{TRANSPaRENCY OF MONETARy POLICY}

1. The assessment of the CNB's observance of good transparency practices relating to monetary policy was undertaken by a two-member staff team ${ }^{5}$ and was based on: (1) a preFSAP questionnaire response; (2) Czech Republic ROSC (IMF, 2000); (3) information available on the CNB website; (4) relevant laws; and (5) discussions with CNB officials and five commercial banks. The assessment was based on the IMF Code of Good Practices on Transparency in Monetary and Financial Policies (MFP Transparency Code). No assessment methodology has been developed as yet, but the assessment has taken into account the implementation issues mentioned in the Supporting Document to the Code.

2. An earlier assessment of the CNB's transparency practices was published by the IMF in August 1999 and updated in July 2000. The assessment carried out by the FSAP mission is, however, the first detailed, practice-by-practice assessment of the CNB's observance with the MFP Transparency Code undertaken in the broader macro-financial context. During the course of the assessment, the Act No. 6/1993 on the Czech National Bank was amended by Act No. 442/2000 Coll. While the act will be effective from January 1, 2001, the assessment has taken into account the legislative changes made with respect to the CNB's role and responsibilities relating to monetary policy.

\section{Legal framework, institutions, and market structure-overview}

3. The Constitution of the Czech Republic (Constitution) establishes the CNB as the central bank of the Czech Republic. The CNB's responsibilities for the formulation and conduct of monetary policy are defined in the Act on the Czech National Bank ${ }^{6}$ (CNB Act) and other acts. ${ }^{7}$ The primary objective of monetary policy, as defined in the Constitution, is to ensure the stability of the Czech national currency. The recently amended CNB Act details this rather general formulation to be understood as maintaining price stability. The CNB Act further stipulates that without prejudice to its primary objective, it shall support the general economic policies of the government leading to sustainable economic growth, and that it shall act in accordance with the principle of an open market economy. The current goal of theCNB is to achieve a low-inflation environment consistent with the criteria for integration into the EU. The principles of the CNB's long-term monetary strategy have been incorporated in a publicly available document of the Czech Government, "Economic Strategy

${ }^{5}$ Udaibir S. Das and Plamen Yossifov, IMF.

${ }^{6}$ Act No. 6/1993 Coll. on the Czech National Bank, last amendment-Act No. 442/2000 Coll., December 2000.

${ }^{7}$ Act No. 576/1990 Coll. on Rules of Performance with Budgetary Means of the Czech Republic and Municipalities, as amended; Act No. 530/1990 Coll. on Bonds, as amended; Act No. 528/1990 Coll. on Foreign Exchange, as amended. 
of the Accession to the European Union," and form part of the joint document of the Czech Government and the European Commission, "Joint Assessment of the Economic Policy Priorities of the Czech Republic."

4. Prior to 1998, the CNB interpreted the rather general formulation of its ultimate objective as a mandate to maintain the external value of the domestic currency (koruna). Since 1998, the CNB has been operating under an inflation targeting framework. In the period 1998-2001, targets were set for the "net inflation," which is calculated as the rate of change of the Consumer Price Index (CPI), excluding administered prices, the effects of changes in indirect taxes, and customs duties. Targets were defined for the value of the 12-month percentage change in the monthly net CPI in December of the following year. In April 2001, the CNB by agreement with the government switched to targeting headline inflation (i.e., growth in the total $\mathrm{CPI}$ ) and to expressing the target trajectory for headline inflation by means of a continuous range. A range was announced starting in January 2002 at 3-5 percent and ending in December 2005 at 2-4 percent.

5. In pursuit of its monetary policy objective, the CNB relies on four monetary policy instruments- the two-week repo rate, the discount rate, the Lombard rate, and the minimum reserve requirement ratio. Due to persistent excess liquidity in the banking sector, in recent years the most actively used instrument is the two-week repo rate. The two-week repo tender of domestic currency bills issued by the central bank is used for liquidity withdrawal and is carried out daily.

6. The governing body of CNB is its Bank Board. The Board consists of seven members, including the governor and two vice governors. All of its members are appointed and recalled by the President of the Czech Republic. The Bank Board, which meets weekly, sets monetary policy and the instruments for implementing these policies. Monetary policy decisions are taken at the last meeting of each month. Within the CNB, the Monetary Department is responsible for analyzing the inflation trends, forecasting macroeconomic conditions and drafting monetary policy proposals for consideration by the Bank Board. The Financial Markets Department is responsible for implementing monetary policy decisions taken by the Bank Board.

\section{Main findings}

7. Overall, the institutional framework, the CNB's relationship with the government, agency responsibilities and operational procedures for the conduct of monetary policy, and monetary policy implementation in the Czech Republic are highly transparent. The main vehicle for ensuring transparency and accountability is through the publication of quarterly Inflation Reports, timely release of summary minutes of the monthly meetings of the Bank Board, publication of commentaries and analysis by high-level CNB officials, and submission of reports on monetary developments to Parliament. 
8. The CNB's responsibilities for formulating and implementing monetary policies and its authority to use monetary instruments are clearly defined in legislation and are publicly disclosed. The relationship between the CNB and the government, and the CNB's broad modalities of accountability are specified in legislation. The framework, instruments, and targets of monetary policy are related to the public through multiple means of disclosure. Information on the macroeconomic situation and its implications for monetary policy are comprehensively disclosed in a timely manner by CNB. The newly amended CNB Act assures CNB accountability to Parliament and the general public. Annual financial reports and 10-day summary financial statements are published regularly and in a timely manner by the CNB.

9. In pursuit of improving further the transparency framework, the main areas where CNB's existing practices need greater clarity and strengthening are described below:

\section{Clarity of roles, responsibilities and objectives of the central bank}

10. The different formulations of the primary objective of CNB in the Constitution and the recently amended CNB Act can potentially convey confusing signals to the public. Transparency relating to the institutional relationship between monetary and fiscal operations carries several gaps. The terms of government deposits at the central bank are not adequately disclosed. CNB responsibilities for the management of domestic and external public debt and foreign exchange reserves are not detailed or explained in CNB publications. The CNB and the MoF are in the process of preparing a formal agreement on the priorities of public debt management. At this stage, it is not clear whether this document will be made public.

\section{Open process for formulating and reporting monetary policy decisions}

11. The conduct of monetary policy and the principles on which it is based are open and transparent. The rules and procedures for the CNB's relationships and transactions with counterparties in the foreign exchange market and the market of government securities, however, are not publicly disclosed. Also, major shortcoming relates to the lack of consultations with market participants and other interested parties at the time of substantive technical changes in the structure of monetary regulations and monetary policy operations. Apart from the fact that practice of such a system would help the market to adequately prepare for operating and regulatory changes, it would also contribute to good governance on the part of the CNB and provide inputs for better and well understood policies.

\section{Public availability of information on monetary policy}

12. The CNB provides a wide range of information and publications and is Special Data Dissemination Standard (SDDS) compliant. The use of the automatic deposit and credit facilities, however, is not adequately disclosed, as their amounts do not appear as separate items in the CNB's balance sheet.

13. The amounts and terms of emergency financial support by the central bank are not publicly disclosed. 
14. The categories in the annual CNB balance sheet and profit-and-loss account change every year, which makes it difficult to conduct consistent comparisons of monetary developments over time.

\section{Accountability and assurances of integrity by the central bank}

15. A high degree of transparency exists with respect to the CNB's public accountability, including preparation of annual report, audited accounts, half yearly report to the legislature on monetary developments and periodic appearances before various committees of the legislature. The Freedom of Information Act requires the CNB to respond in writing to individual requests for information within 15 days. However, the CNB's internal governance procedures are not publicly disclosed.

\section{Recommended action plan and authorities' response}

\section{Table 8. Monetary Policy Transparency: Assessment Recommendations}

\begin{tabular}{|c|c|}
\hline Subject & Recommendat \\
\hline $\begin{array}{l}\text { 1. Clarity of roles, responsibilities } \\
\text { and objectives of ceatral banks for } \\
\text { monetary policy }\end{array}$ & $\begin{array}{l}\text { The terms of government deposits at the central bank should be publicly } \\
\text { explained in CNB publications. } \\
\text { CNB responsibilities for the management of domestic and external public } \\
\text { debt, foreign exchange reserves, as banker, and advisor on economic and } \\
\text { financial policies of the government should be stated and explained in its } \\
\text { Annual Report and other publications. }\end{array}$ \\
\hline $\begin{array}{l}\text { U. Open process for formulating } \\
\text { and reporting monetary policy } \\
\text { decisions }\end{array}$ & $\begin{array}{l}\text { Internal regulations on the rules and procedures for the CNB's } \\
\text { relationships and transactions with counterparties in the foreign exchange } \\
\text { market and the market of government securities should be publicly } \\
\text { disclosed. } \\
\text { Changes in monetary regulations should be consulted with market } \\
\text { participants and other interested parties. }\end{array}$ \\
\hline $\begin{array}{l}\text { III Public availability of } \\
\text { information on monetary poficy }\end{array}$ & $\begin{array}{l}\text { Data on the use of the automatic deposit and credit facilities should appear } \\
\text { as separate categories respectively on the liabilities and assets side of the } \\
\text { CNB balance sheet. } \\
\text { In compliance with the statement on data availability posted on the IMF's } \\
\text { Dissemination Standards Bulletin Board, the Czech Republic as a } \\
\text { subscriber to SDDS should publish the aggregate amounts of refinancing } \\
\text { credits to domestic banks as part of its SDDS data template. } \\
\text { To ensure comparability of CNB balance sheet data across time, the } \\
\text { central bank should avoid frequent changes in the grouping categories of } \\
\text { its assets and liabilities. Thought might be given to reissuing its past } \\
\text { balance sheets using consistent set of definitions of these categories. } \\
\text { Consistent with confidentiality and privacy of information on individual } \\
\text { banks, aggregate information on emergency financial support by the } \\
\text { central bank should be publicly disclosed. }\end{array}$ \\
\hline dissuranoe & The CNB's internal governance procedures should be publicly explained. \\
\hline
\end{tabular}


16. In its response, the CNB expressed reservations regarding the assessors' recommendation to institute procedures for consultation with market participants and other interested parties on changes in monetary regulations. The CNB's view is that such consultations would result in delays in the implementation of regulatory changes without affecting the final outcome, as CNB would not be bound to take into account market participants' views. The the CNB further noted that if the reason for the proposed consultations is to acquaint market participants with planned regulatory changes, the CNB is already doing this in advance. The CNB did not find appropriate the recommendation that its internal governance procedures should be explained to the general public, on the grounds that such disclosure could reduce its internal operational independence.

\section{Basel Core Principles for Effective Banking SUPERVISION AND Transparency OF BANKING SUPERVISION}

\section{A. Basel Core Principles}

17. The assessment of the CNB's compliance with the Basel Core Principles for Effective Banking Supervision (CPA) was conducted by a three-member team ${ }^{8}$ and was based on (1) a pre-FSAP questionnaire response; (2) Czech Republic ROSC (IMF, 2000); (3) a recent revised self assessment prepared by the $\mathrm{CNB}$; (4) information available on the CNB website; (4) relevant laws and prudential regulations; and (5) discussions with CNB officials and five commercial banks, the accounting, auditing, and bankers' associations, and a major auditing firm.

18. Based on the Basel Committee's Methodology for Assessment of the Core Principles, the Czech Republic's compliance was separately assessed against "essential" and "additional" criteria. This implies that the Czech Republic, in addition to seeking to fulfill the international minimum standards also strives to apply international best practice. The Czech authorities cooperated fully with the assessment and provided all the necessary clarification and documents.

19. During the course of the assessment, the amendments to the Act on Banking, No. 21/1992 Coll. (AoB) that were aimed at harmonizing the legal framework with the relevant EU directives were rejected by the Parliament. The amendments were particularly aimed at modifying the licensing requirements, implementation of a consolidated supervisory approach with suitable modifications in capital adequacy, credit exposure and liquidity

${ }^{8}$ Udaibir S. Das (IMF), Antonio J.V. Aguas (Banco de Portugal), and Andy Beadle (Financial Services Authority, United Kingdom). Mr. Aguas has 25 years of experience in the area of banking policy and supervision, while Mr. Beadle has been a practicing banking supervisor for the last six years. 
requirements, and a redefinition of the deposit insurance system for banks. The assessment, therefore, is based on the present situation as to laws, regulations and supervisory practices of the CNB.

\section{Institutional and macroprudential setting, market structure—overview}

20. The commercial banking sector has been undergoing fundamental structural changes during the 1990s. The second half of the 1990s, particularly the period after 1996, has been a critical period for the Czech banking system, marked by deterioration in the loan portfolio, placement of banks under conservatorship, revocation of as many as 16 banking licenses, tightening of provisioning norms, mergers, continuing transfer of bad debts to KOB, privatization of large state-owned commercial banks, the problem of the IPB sale, and mounting fiscal cost of the bank restructuring and privatization effort. Apart from the resources required to manage such an operation, the complex legal, institutional, and administrative processes have made it a demanding task.

21. The banking system presently consists of 40 licensed institutions-KOB, 13 Czechowned banks and 26 foreign banks-dominated by the three largest banks (CSOB, KB, and CS). The three banks have a combined market share of 60 percent. Subsidiaries and branches of foreign banks account for 31.3 percent of the total assets, while the small- and mediumsized domestic banks have a market share of 1.6 percent. In addition there are six building societies, and three specialized financial institutions (licensed as banks).

22. The bank privatization process gained momentum during 1999 and 2000 with the sale of CSOB in July 1999 and sale of majority ownership in CS in March 2000. KB is being prepared for sale in 2001. The failure of IPB that was sold to Nomura in 1998 has however provided a setback to the restructuring process and raised several questions relating to early detection of problems in banks, internal control systems, and the role of external auditors. To deal with the problem loans, the government, with the active involvement of the $\mathrm{CNB}$, has set up a variety of workout modalities to acquire the bad loans and clean up the bank balance sheets to promote privatization.

23. The Czech banking system continues to face significant challenges and opportunities in the future. The evolving banking structure, emergence of financial conglomerates, changing ownership structure of the banks, growth in the nonbank sector, has led to a fundamental change in the competitive character of the banking industry. The earnings environment remains weak, as do the avenues for high margin investments. The banking system as it stands today, is highly liquid, marginally profitable, and is making strategic shifts in its business orientation in order to maintain its operating profitability. 


\section{Preconditions for effective banking supervision ${ }^{9}$}

24. While the Basle Core Principle assessment was not undertaken to evaluate the supervisory performance during the restructuring phase, the assessment has shown that the CNB has responded to these challenges by strengthening the supervisory framework, including enlarging the requirements for licensing, tightening provisioning rules, enhanced disclosure requirements, strengthening supervisory resources, stricter requirements relating to bank auditors, and automatic revocation of license in cases where the capital adequacy drops below a minimum stipulated ratio.

25. The supporting legal system, however, is in transition, and the legislative changes made during 2000 remain largely untested in terms of the way they relate to the banking system. The overall objective is to adapt laws and regulations to conform to EU directives. In addition, the approach is to remedy the current imbalance favoring the debtor vis-a-vis the creditor in the existing laws. The legal reform has included the overall recodification of the commercial law, a reconstruction of the bankruptcy law, and changes in the legal regime of pledges and possessionary lien. Amendments to the CNB Act have been adopted while a new Public Auction Law is in place.

26. The supervisory staff is gaining in professionalism, and its awareness and understanding of international supervisory standards, policies, and practices are very high. However, the current skills to assess market risk, audit computer based systems and evaluate risk management systems are low. This is coupled with a thin complement of supervisors who mainly conduct traditional full-scope inspections and have yet to begin a systematic process to carry out risk-based inspections. The CNB is planning to strengthen training and building of special skills in these new areas.

27. The CNB operates with a relative high degree of independence on supervisory policies. However, on bank restructuring and problem banks, the CNB's supervisory practices require it to work closely with the government and agencies responsible for implementing laws that directly affect banking operations. ${ }^{10}$ Furthermore, the CNB is

\footnotetext{
${ }^{9}$ See Core Principles for Effective Banking Supervision (Basel Core Principles), September 1997 and Core Principles Methodology, October 1999.
}

${ }^{10}$ These include: conduct of supervision: the State Inspection Act (1991), Act on Liability for Damage Caused in the Execution of Public Authority by decision or Incorrect Official Procedure (1998), Code on Administrative Procedures (1967), Act on Auditors (2000); resolution of problem banks. The Code of Civil Procedures (1963), Act on Public Auctions (2000), Act on Bankruptcy and Settlement (2000). The core acts are the CNB Act (2000) and the Act on Banks (1992). Banking operations are also required to be undertaken within the framework of the Foreign Exchange Act (1995), the Securities Act (1992), the Civil Code 
required to consult with the MoF prior to licensing a new bank, although the final decision of whether to grant a new license is taken by the CNB. In practice, the large array of laws, inefficiencies in the judicial processes and cumbersome administrative requirements impedes effective and timely supervisory enforcement and intervention in the case of problem banks. Supervision is also subject to strict secrecy requirements that restrict information sharing among domestic and foreign supervisors. The laws and administrative procedures on money laundering lag behind those in other countries and need strengthening. The CNB is fully cognizant of these limitations and has been taking up the subject of legal and administrative reforms with the government. The amendments to the $\mathrm{AoB}$ that were recently rejected by Parliament would have considerably strengthened the supervisory powers and supported the effective implementation of supervisory policies and regulations.

28. Regarding accounting practices, Czech banks are required to follow Czech accounting standards. While close to International Accounting Standards (IAS), differences remain in two areas, namely in the areas of consolidation and accounting for fair value of financial instruments. By law, banks must appoint an external auditor and notify the CNB of the selection. Auditors' unqualified opinions state that a bank's financial statements are audited in accordance with the Act on Auditors and the Chamber of Auditors that they present fairly, in all material respects, the condition and the results of the bank in accordance with the Act on Accounting, and that they are prepared from accounting records which are in accordance with the Act on Accounting. In the case of most major banks, accounts are also audited in accordance with International Standards on Auditing and their statements prepared in accordance with IAS.

\section{Main findings}

29. The Czech banking system practices universal banking. Banking sector involvement in the insurance and securities sectors is growing. Ownership structures within the banking sector are changing and the market share of branches and subsidiaries of foreign banks is expanding. There is increasing need to ensure that banks systematically measure and monitor the growing market risks. Banks are also facing competitive pressures in a difficult earnings environment. This may lead to aggressive and risky lending behavior in some banks and the exploitation of cross-sectoral business opportunities as banks seek to maintain profit levels and will require enhanced credit administration and internal control systems.

30. At an operational level it is worth noting that the general quality of CNB supervisors appears to have improved in the recent period. Extensive training programs and technical assistance have deepened the supervisors' understanding of the business and control risks faced by Czech banks. However, the availability of supervisory resources remains a key issue

(1964), the Commercial Code (1991), Act on Bonds (1990), and the Act on Building, Savings and State Aid to Building Saving (1993). 
and staff turnover rates among CNB supervisors are already at very high levels. Should the attrition rate remain at the current level, or increase further, it would almost certainly weaken the CNB's ability to regulate the banking sector.

31. Steps are underway to strengthen the legal framework and prudential requirements. The AoB has been amended 11 times since 1992, although the recent round of amendments, mainly in preparation for EU accession and to improve the CNB's oversight of the banking system, failed to receive Parliamentary approval and will need to be resubmitted. This will delay the required legal reforms in key supervisory areas such as consolidated supervision. The prudential framework was strengthened in April 2000 with the introduction of the modified capital adequacy requirement based on market risk on a solo basis. Reporting of capital and large exposures on a consolidated basis was introduced in January 2000 covering only credit risk.

32. A number of other supervisory issues came up during the Core Principle (CP) assessment that require attention Although the CNB has implemented a capital adequacy (CP 6) requirement for credit and market risk, it is on a solo basis only. At the consolidated level banks are only required to calculate a capital adequacy ratio for credit risk. The CNB plans to expand the coverage of the consolidated capital ratio to include market risk in early 2002. ${ }^{11}$

33. Credit risk (CP 7) remains the key risk facing the Czech banking sector, as evidenced by the scale of nonperforming loans within the country. With the large inflow of foreign investment into the $\mathrm{Czech}$ banking sector, a number of banks have imported credit systems from their parent operations. While this is likely to encourage an improvement in the practice of credit management, there are no formal requirements within the Czech banking regulations for banks to set out their policies, practices and procedures relating to the credit process (origination, ongoing management, etc). The position is similar for other risks

\footnotetext{
${ }^{11}$ While the assessment is based on current regulations and supervisory practices, it recognizes that the $\mathrm{CNB}$ and the MoF are making efforts at introducing decrees on capital adequacy based on credit and market risk on a consolidate basis, improved disclosure through financial statements on a consolidated basis, acquisition of voting shares and decrease in holdings in banks, operating a credit register; regulations relating to liquidity risk and widening the loan classification and provisioning requirements to include additional off-balance sheet items; supervisory tools such as a manual to evaluate and control over bank's internal control systems, principles of management of credit risk and management of market risk and an internal manual for licensing procedures, development of a standardized memorandum of understanding to be used for information sharing agreements with foreign supervisors and development of an internal VaR model for measuring market risk. Issuance of some of the decrees and regulations would however require amendments to the AoB.
} 
(CP 13) where, apart from market risk in the trading book, there are no formal requirements for banks to put in place comprehensive procedures for risk management.

\section{In terms of anti-money laundering (CP 15) controls, "know-your-customer"} requirements are not explicitly set out within the banking regulations. The banks are presently not required to report to the supervisor any suspicious activities and incidents of fraud which might threaten the safety, soundness or reputation of the bank. At present the scope of consolidated supervision (CP 20) in the Czech Republic only relates to groups headed by a bank. A planned amendment to the Act on Banks should allow the CNB to require consolidated reporting from financial holding companies and greater access to information from mixed holding companies where there is a bank presence. Similarly, the CNB currently has limited powers in respect of global consolidated supervision (CP 23). While the CNB can supervise overseas branches and foreign subsidiaries of Czech banks (subject to local laws), it only has very limited powers to restrict the activities of those operations or to require their closure should they pose a threat to the bank as a whole. There is also a need for strengthening, on a priority basis, mechanisms for coordinated supervisory information sharing and action, wherever required, among the CNB, the MoF (insurance), and the CSC (securities).

35. In addition, efforts are needed to improve the implementation and compliance with the following core principles where shortcomings were assessed. Specific recommended actions have been indicated in Table 9 against the respective principles: CP 1 (objectives); CP 2 (permissible activities); CP 3 (licensing criteria); CP 4 (ownership); CP 6 (capital adequacy); CP 8 (loan evaluation); CP 9 (large exposures limits); CP 10 (connected lending); CP 11 (country risk); CP 12 (market risk); CP 14 (internal control and audit); CP 16 (on-site and off-site supervision); CP 17 (bank management); CP 18 (off-site supervision); CP 19 (validation of information); CP 21 (accounting standards); CP 22 (remedial measures); CP 24 (host country supervision); and CP 25 (supervision of foreign establishments).

\section{Recommended action plan and authorities' response}

Table 9. Summary of Main Findings and Recommendations

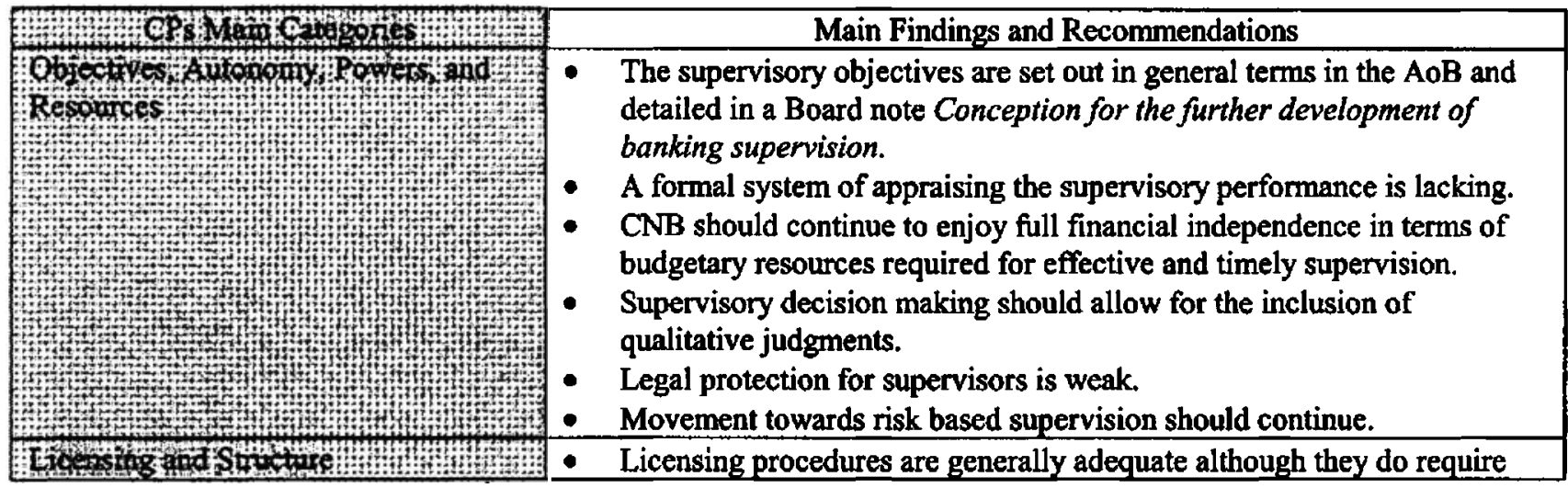




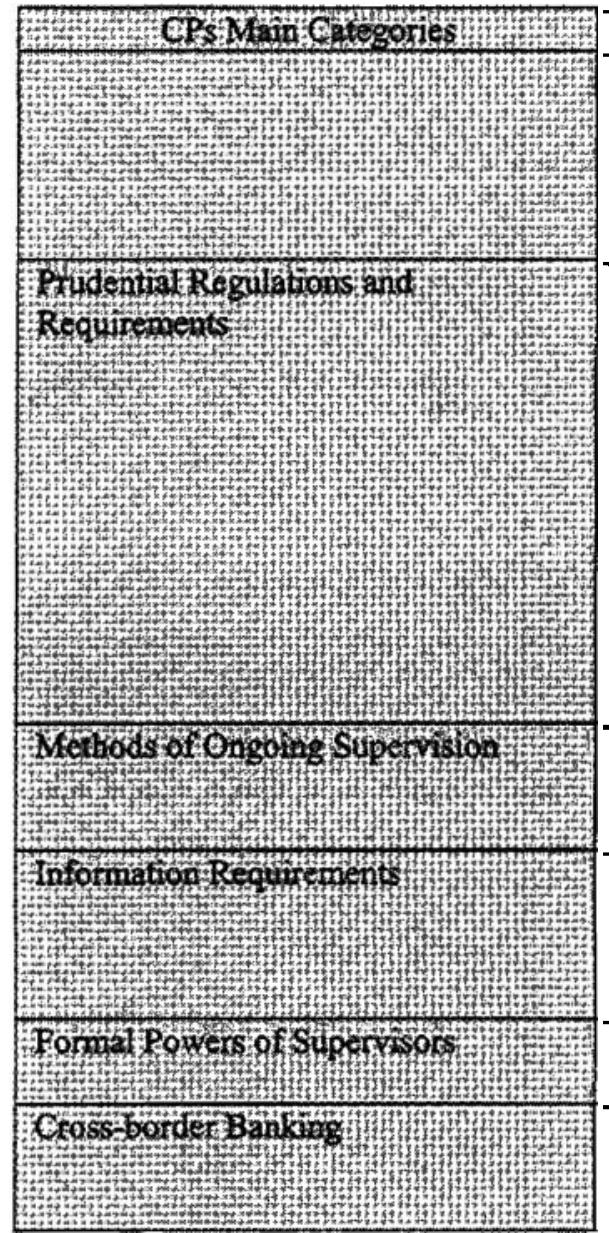

Main Findings and Recommendations

strengthening in parts such as identification of beneficial owners of banks and in terms of the powers of the CNB to enforce the law against unauthorized use of the term "bank."

- Fit-and-proper criteria should be considered in respect of senior management below Board level.

- While many of these requirements are met in practice, the prudential framework relating to credit risk, in particular, and other risks in general need to be strengthened.

- In particular, a formal requirement for banks to formulate adequate credit risk management procedures needs to be put in place.

- Use of differential capital ratios based on an individual bank's business and control risks should be considered.

- There is a need to develop understanding of market risk and VaR methodologies.

- "Know-your-customer" requirements should be explicitly set out in the banking regulations.

- Ongoing supervision is generally adequate but action required to extend consolidated supervision to financial holding companies and mixed holding companies.

- Further harmonization of Czech accounting standards with internationally accepted accounting principles and procedures is required, such as those relating to leasing and fair value accounting in relation to financial instruments.

- Supervisory powers for prompt corrective action need to be made explicit and strengthened.

- Cross-border supervision is weak. In particular the CNB has no powers over foreign subsidiaries of Czech banks. Nevertheless the accounts of foreign subsidiaries of Czech banks are consolidated.

36. The CNB commented that they were generally in agreement with the overall assessment. On the $\mathrm{CP}$ relating to money laundering, the $\mathrm{CNB}$ was of the view that the existing legislative and institutional arrangements were adequate. In particular, they noted that according to the law of anti-money laundering procedures banks are required to report suspicious activities to the Financial Analytical Section at the MoF, which is responsible for implementing and supervising observance of the anti-money laundering law. The CNB in onsite examinations does verify that banks comply with this requirement. The introduction of separate CNB regulations on this matter would, therefore, only lead to duplication of efforts.

\section{B. Transparency of Banking Supervision}

37. The assessment of the CNB's observance with good transparency practices relating to banking supervision was carried out by a two member staff team. ${ }^{12}$ It was based on the $I M F$ Code of Good Practices on Transparency in Monetary and Financial Policies (MFP

${ }^{12}$ Udaibir S. Das and Plamen Yossifov (IMF). 
Transparency Code). The assessment took into account the implementation issues mentioned in the Supporting Document to the Code. The first assessment of the CNB's transparency practices, including its self-assessment of compliance with the Basel Core Principles for Effective Supervision, was published by the IMF in August 1999 and updated in July 2000. The assessment carried out by the FSAP mission was, however, the first detailed, practice-bypractice assessment of the CNB's observance with the MFP Transparency Code as it relates to banking supervision in the broader macro-financial context. It supplements the Basel Core Principles assessment of the efficacy of the regulatory and supervisory polices.

\section{Institutional and market structure-overview}

38. The CNB is the primary agency responsible for banking supervision in the Czech Republic. It derives it authority from the CNB Act and the Banks Act. The CNB has full operational and financial independence on supervisory matters, although on matters relating to licensing, revocation of licenses and resolution of problem banks, the CNB works in close coordination with the MoF. Similar to the proactive approach towards disclosure and transparency in its conduct of monetary policy, the CNB pursues an open policy on supervisory policies and regulations. The public is acquainted with banking sector developments and supervisory matters through multiple means of disclosure, including an annual report on banking supervision, a dedicated chapter in the CNB Annual Report, the data bulletin "Basic Indicators of the Banking Sector," and regularly updated web pages on the CNB website.

\section{Main findings}

39. Banking supervisory policies, regulations and developments are provided to the market and public in a comprehensible, accessible and timely manner. The CNB provides a basic overview of the regulatory framework within which the banks operate, informs the market of the changes in the regulations, makes public its review of the supervisory activities, informs banking consumers of the products and services offered by banks, discloses basic data on the state and performance of the banking sector in terms of its structure of assets and liabilities, off-balance sheet activities, foreign exchange operations and detailed aggregate data on the banking system that can be used for independent evaluations and public monitoring of bank's compliance with the prudential requirements.

40. The CNB uses a variety of means and methods of communicating with the public on its supervisory role, polices and operations. It goes beyond relying only on regulation and legislation, which by their nature are public documents. Active use is made of the CNB website to disclose information to a wider group. Also used are less formal and more flexible disclosure forms such as press releases and appearances by officials before public audiences and legislature, and publications such as the annual report on banking supervision.

41. The quality of information disclosed has been improving in terms of content and clarity. In the area of data disclosure, the Czech Republic meets the SDDS specifications for 
the coverage, periodicity, and timeliness of banking sector data and for dissemination of advance release calendars. In the second half of 2000 , the CNB began publishing aggregate banking sector indicators on a quarterly basis.

\section{Clarity of roles, responsibilities, and objectives of financial agencies}

42. The broad objectives and supervisory role of the $\mathrm{CNB}$ is well-defined and based on sound legal foundation. These objectives, however, require greater specificity and should be modified to reflect the supervisory challenges confronting the CNB consequent to the bank restructuring process. Another issue relates to the clarity with respect to the role and responsibilities among the CNB (banking supervision), the $\mathrm{MoF}$ (insurance supervision), and the CSC (securities supervision) to the extent it relates to matters involving firms operating in all the three segments of the financial system. Universal banking is practiced in the Czech Republic and there is a large presence of financial conglomerates. This requires clarity in terms of how the three agencies interact and work together. An MOU between the CNB, the MoF, and the CSC exists from 1998, but it has neither been publicly disclosed, nor has any effort been made to explain the scope and nature of the arrangement relating to information sharing and areas of respective responsibilities as they relate to the operations of such holding companies. This disclosure would enable the market and the public to gain reassurance that the CNB has established a mechanism for cross-border regulatory of banking-related issues that may have an impact on the domestic banking sector.

\section{Open process for formulating and reporting of financial policies}

43. As mentioned, the CNB has a fairly open approach towards formulating and explaining developments relating to supervisory polices. It consults with the banking industry on all regulations and draft decrees in the area of banking supervision. However, the operating procedures, such as those relating to testing the fit-and-proper criteria, evaluating internal control systems, holding company supervision, supervisory measures to prevent unauthorized lending to connected parties, are not publicly disclosed.

\section{Public availability of information on financial policies}

44. While the CNB pursues a conscious policy to make information on supervisory issues available widely through the use of multiple means, there are three areas where shortcomings exist. First, data on the use of the automatic deposit and credit (Lombard loans) facilities by banks are not publicly disclosed. Second, the aggregate amounts of refinancing credits to domestic banks are not published as part of the SDDS data template, despite the statement to the opposite effect posted on the IMF's Dissemination Standards Bulletin Board. Finally, while there is the issue of secrecy and confidentiality to be recognized in the Czech system, information on emergency financial support by the CNB on an aggregate basis is not publicly disclosed. A transparent supervisory framework would be considerably strengthened if in such cases information were disclosed and explained, exercising judgment on the timing and 
stability of the financial markets. Good governance also requires disclosure of funds used in public interest. It helps raise the credibility of the supervisor in emergency situations.

\section{Accountability and assurances of integrity by financial agencies}

45. Finally, with respect to transparency practices relating to accountability and assurances of integrity, the accountability framework is well-defined. However, the CNB's internal governance procedures and rules and procedures aimed at preventing exploitation of conflicts of interest are not publicly disclosed. This would raise market confidence in the supervisory staff who have access to privileged/confidential financial-related information. Disclosure of such standards would also imply that the CNB has set standards for its supervisory staff under which the staff and officials are bound to operate.

\section{Recommended action plan and authorities' response}

Table 10. Banking Supervision Transparency: Assessment Recommendations

\begin{tabular}{|c|c|}
\hline Subject & Recommendations \\
\hline $\begin{array}{l}\text { V. Clarity of roles, responsibilities and objectives of } \\
\text { banking supervision agencjes }\end{array}$ & $\begin{array}{l}\text { The scope and procedures for cooperation and } \\
\text { information sharing, laid down in the } 1998 \mathrm{MOU} \\
\text { between the CNB, the MOF, and the CSC should be } \\
\text { explained to the public. }\end{array}$ \\
\hline $\begin{array}{l}\text { V. Open process for formulating and reporting of } \\
\text { banking supervision policies }\end{array}$ & $\begin{array}{l}\text { The internal procedures for the conduct of the banking } \\
\text { supervision should be publicly disclosed. } \\
\text { The provisions of MOUs with foreign banking } \\
\text { supervisory authorities should be publicly disclosed. }\end{array}$ \\
\hline $\begin{array}{l}\text { VI Public availability of information } \\
\text { supenvision policies }\end{array}$ & $\begin{array}{l}\text { Consistent with confidentiality and privacy of } \\
\text { information on individual banks, aggregate } \\
\text { information on emergency financial support by the } \\
\text { central bank should be publicly disclosed. }\end{array}$ \\
\hline $\begin{array}{l}\text { VIII. Accountability and assurance of integrity by } \\
\text { banking supervision agencies }\end{array}$ & $\begin{array}{l}\text { The CNB's internal governance procedures should be } \\
\text { publicly disclosed. } \\
\text { Internal rules to prevent exploitation of conflicts of } \\
\text { interest should be publicly disclosed. }\end{array}$ \\
\hline
\end{tabular}

46. The CNB was in agreement with the assessment's findings and recommendations.

VIII. IAIS Core Principles and Transparency of Insurance Regulation

\section{A. IAIS Insurance Core Principles}

47. The assessment of the Office of State Supervision of Insurance and Pension Funds' (the "Office") compliance with the IAIS Insurance Core Principles was based on: (1) a pre- 
FSAP questionnaire response; (2) a self-assessment against IAIS Core Principles; (3) relevant laws and regulations, and (4) discussions with supervisory staff of the Office. ${ }^{13}$

48. This assessment was based on the IAIS Core Principles Methodology document (2000). Consideration was also given to the Supervisory Standard on Solvency Assessment. The legal framework for the Czech insurance sector is based on Act No. 363/1999 and Decree No. 75/2000, which proclaimed the Act in force. Relevant sections of the Commercial Code and the Accounting and Auditing Acts also apply to the insurance sector. Supervision of the sector is performed by the Office within the MoF. The Office was until recently a department of the MoF. The supervisory staff of the Office cooperated extensively in the assessment, by providing answers to an extensive questionnaire, preparing a self-assessment against IAIS Core Principles, and making themselves available to meet with mission members at every opportunity.

49. The Office operates under a strict rule of confidentiality. Thus, staff were not authorized to provide information concerning specific companies. As a result, much of the data collected was obtained from the Czech Insurance Association and from individual insurance companies.

\section{Institutional and market structure-overview}

50. There are 41 licensed insurance companies operating in the Czech Republic, of which 7 are branches of foreign insurance companies and the others are incorporated locally. Fifteen of the local companies are controlled by foreign capital and four are subsidiaries of Czech banks. Three of the companies do only life insurance business, 20 do only non-life insurance business, and the other 18 are composites.

51. Total premiums received by Czech insurance companies during 1999 amounted to CZK 62.8 billion, of which CZK 19.8 billion (32 percent) was for life insurance and CZK 43.0 billion for non-life insurance. Total premium income is estimated to represent 3.4 percent of GDP. An insurance penetration of these proportions ranks the Czech Republic as a leader among transition economies in the region, although it would still be far below the situation prevailing in the EU. Total assets for Czech insurance companies as of the end of 1999 amounted to CZK 156.6 billion, or approximately 8.5 percent of GDP.

52. The Czech Republic has adopted the EU formula for minimum solvency of insurance companies. As of the end of 1999 , most companies had solvency positions that exceeded minimum requirements by a comfortable margin. For example, the average solvency margin for non-life companies was four times average requirements. The Office reports that only two companies, with market shares of 0.16 percent and 0.18 percent, respectively, failed to meet the minimum margin as at the end of 1999.

${ }^{13}$ Undertaken by Donald McIsaac (World Bank). 
53. The year 2000 is a key transition year for the industry and particularly for the regulatory and supervisory framework. With the adoption of the new legislation, a major change has been effected in the manner of supervising companies. In line with practices in the EU, prior formal approval of product and premium rates has been abandoned. Emphasis must now be placed on the monitoring of company financial strength, or solvency, on a permanent basis. This modern approach to supervision demands a higher level of professionalism from supervisory personnel. Analysis and inspection must now be focused on key risk areas if they are to be effective. Under the new law, both life and non-life insurance companies will be expected to appoint an actuary to provide an annual report on the adequacy of technical provisions and other key factors. The supervisory personnel will be expected to work with the actuaries, and indeed the auditors, as joint participants in the work of prudential oversight of the industry. The reclassification of the supervision function from a department of the MoF into an Office is seen as the first step in the institutional restructuring of insurance supervision.

\section{General preconditions for effective insurance supervision}

54. The legal system in the Czech Republic is similar to that which prevails in Germany. Companies are incorporated according to the Commercial Code, while relationships with consumers are governed by the Civil Law. Unfortunately, these laws have not been kept up to date. For example, the Civil Law does not contain all the provisions that are needed to protect consumers of insurance policies. There have been discussions to create a special Insurance Contract Law as many countries have recently done (e.g., Argentina). A draft of the proposed Insurance Contract Law has been submitted to the Czech Government and is expected to be passed to Parliament in the near future. The legal framework for insurance is also weak in the area of corporate governance. Recent amendments to the Commercial Code strengthening corporate governance became effective in January 2001, and also apply to insurance companies. This is a positive step, but the provisions in the Commercial Code are general and do not go far enough in protecting the interests of policyholders and account-holders in financial institutions. The new Insurance Law, which became effective in April 2000, should have included special provisions outlining the responsibilities of directors and identifying certain key roles they must play.

55. In general, however, the new Insurance Law represents a significant improvement over the previous law and constitutes a good and modern piece of legislation. In particular, the new Law provides the supervisors with several important tools for dealing with distressed insurance companies. For example, the law prescribes certain actions that must be taken when a company's solvency margin falls below a specified level (the "guarantee" fund). In addition, there are special powers to be applied at the discretion of the supervisor when other less threatening situations are presented.

56. Accounting and auditing legislation are also relevant for the performance of the insurance sector. Accounting for insurance companies is governed by the general Law on Accounting. The MoF has authority to issue special accounting rules for insurance companies 
and this was done through a special regulation issued by the MoF. Recent amendments to the Auditing Law that will become effective in January 2001 may have important impact on the way the sector operates. These amendments include, inter alia, the legal obligation for the auditor to inform the supervisor of any breaching of the law, or of a situation is developing that could impair the ability of the company to meet its obligations. Enforcement of this new provision remains to be tested, however.

57. The Czech Insurance Association has adopted a code of ethics for its members. In addition, through its monitoring activities, it is well-placed to give advance warning of companies that are headed for financial difficulties. The association is prepared to expel a member company that gives cause for concern. While it is not strictly speaking an SRO, it behaves in a similar manner.

\section{Main findings}

58. The regulation and supervision of the Czech insurance sector has improved in recent years, with the adoption of a more modern insurance law that is more harmonized with EU legislation, and that, inter alia, introduces EU solvency criteria. The Supervision Office is also obtaining technical assistance from EU members and strengthening its supervisory staff.

59. The legislation needs to be further strengthened in some important areas, however. Corporate governance of insurance companies relies on general provisions of the Commercial Code. Although these provisions have been recently strengthened, they are still insufficient to ensure sound governance of insurance companies. Explicit requirements for the boards of insurance companies, particularly in the area of internal controls, are not adequate. There is also a need to strengthen legislation in specific areas, such as licensing, change in control, use of derivatives, reinsurance, and market conduct.

60. The supervisory authorities also lack sufficient legal and operational independence, being located in a department inside the MoF. The lack of sufficient resources for more effective supervision is particularly reflected in the low frequency of on-site inspections, and the absence of sufficient supervisory skills in the areas of risk management and internal controls. The development of an adequate supervisory function will require more legal and operational independence and more adequate resources for staffing and training.

61. Table 11 provides a summary of the main findings of the detailed assessment and related recommendations. 
Table 11. Summary of Main Findings of Assessment of Observance of the IAIS Insurance Supervisory Principles

\begin{tabular}{|c|c|c|}
\hline Subjed & & Main Findings \\
\hline Organization of an Insurance Supervisor & & $\begin{array}{l}\text { The Supervision Office lacks independence. There is } \\
\text { need for additional resources and training }\end{array}$ \\
\hline 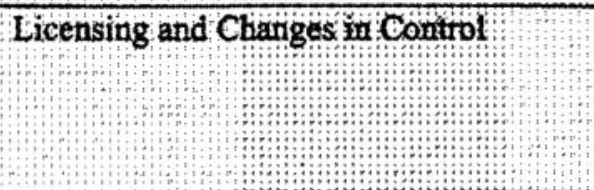 & & $\begin{array}{l}\text { Need to strengthen licensing procedures to include } \\
\text { explicit reference to the tinancial soundness of owners } \\
\text { and fit and proper tests for management. There is a } \\
\text { need for more explicit conditions regarding the } \\
\text { acguirer when changes in control are proposed }\end{array}$ \\
\hline Corporate Governance & & $\begin{array}{l}\text { Corporate governance rules need to be introduced in } \\
\text { the Insurance Act. Rules in the Commercial Code do } \\
\text { not offer sufficient protection for insurance } \\
\text { policyholders }\end{array}$ \\
\hline Internal Controls & & $\begin{array}{l}\text { New provisions in the Insurance Act addressing } \\
\text { internal controls need to be introduced. New } \\
\text { inspection procedures need to be introduced to } \\
\text { encompass risk management and internal controls. }\end{array}$ \\
\hline Pridential Rúles: & & $\begin{array}{l}\text { Supervisory procedures should be developed for } \\
\text { dealing with issues not specified in legislation, such as } \\
\text { matching. Office must develop new procedures for } \\
\text { review of reinsurance arrangements, including the } \\
\text { assessment of teceivables. A system of controls and } \\
\text { disclosure requirements for derivatives and off-balance } \\
\text { sheet items should be prescribed }\end{array}$ \\
\hline Market Conduct & & $\begin{array}{l}\text { Office of Supervision must establish a consumer } \\
\text { protection program }\end{array}$ \\
\hline Monitoring, Inspection and Sanctions & & $\begin{array}{l}\text { Minimum frequency of inspections is required. There } \\
\text { is also a need to enhanced training program of on-site } \\
\text { inspections }\end{array}$ \\
\hline Cross-border Business Operations: & & $\begin{array}{l}\text { This principle will become applicable as the country } \\
\text { approaches EU membership. }\end{array}$ \\
\hline
\end{tabular}

\section{Recommended action plan and supervisory response to the assessment}

\section{Recommendations}

62. The Czech authorities should focus their efforts in strengthening the system of insurance supervision. The Office should develop a strategic plan for restructuring its operations and adopting the techniques and procedures expected of those companies that adopt the EU directives. This strategic plan would have several steps:

- identification of the special technical skills that the Office will require, including lawyers; actuaries; auditors; loss appraisers;

- redesign of the organization chart for the Office;

- plan for development of new procedures that will modernize the activities of the Office and bring them more into line with international practice;

- preparation of operational manuals and other work instruments that will be needed under the new style of operations; 
- $\quad$ training program for existing staff; and

- $\quad$ recruitment of additional personnel, where necessary professional skills are not presently available.

63. As mentioned before, a major shortcoming of the present supervisory system is the failure to conduct on-site inspections with any frequency and with a risk focus. This will only change when additional human resources are provided to the office and staff are properly trained in the procedures for risk-based inspections. As a first step toward filling this gap, a plan of action has been prepared for the coming year, which includes the development of a manual for on-site inspections. The observance of principles of good corporate governance, such as those related to internal controls, investment policies and the monitoring of transactions with related parties, will only improve with the introduction of new provisions to strengthen the requirements for good corporate governance among insurance companies in the Insurance Law. The Office is fortunate to have the benefit of assistance from the German Office of Insurance Supervision supported by funding from the EU-Phare program. The resident expert has prepared a work program for the coming year that will help the office to make necessary changes in operation. This assistance should be incorporated into the strategic plan to be developed. The following specific features will be addressed by the German expert:

- improvement of accounting rules for insurance companies;

- development of a manual for inspections; and

- assistance with enhancement of a consumer protection program, including the introduction of an "ombudsman" role for the Office.

64. These planned measures will help to remedy the concerns identified in the assessment of observance of IAIS Core Principles. However, there are some important measures that should be adopted immediately as standard procedures for the Office:

- On-site inspection must become a routine part of the supervisory process. Each company should be inspected each year, or at least every two years;

- Inspection and analysis work should be directed according to risk assessment. Supervisory resources should be applied to those areas of a company's operations that represent the most serious threats to the long-term solvency of the company;

- Supervisory staff must develop skills in assessing the appropriateness of matching of assets and liabilities as it is practiced by local companies;

- A systematic program for review and assessment of reinsurance programs must be developed for the work of supervisory teams and techniques for the evaluation of reinsurance receivables developed; and

- Technical assistance should be obtained to assist with the development of an effective program of consumer protection. 


\section{Supervisory response}

65. The Office has provided the following observations concerning the assessment:

- The staff of the office does not agree with the observation that the insurance legislation should be strengthened in those areas that relate to licensing.

- The staff agree that there bas been a low frequency of on-site inspections in the past but they point out that such inspections are becoming more and more frequent. In response to the assessment of $\mathrm{CP} 13$, the Office has observed that with its recent reorganization and the acquisition of new staff, there are permanent tendencies for step-by-step improvement of the frequency of controls.

- In respect of reinsurance (CP 10), the Office has responded that increasing accent is being given to the importance of reinsurance programs, despite the fact that the Office does not have the legal authority to order or reject a specific reinsurance arrangement.

- With regard to the recommendations for further action, the Office would delete the reference to the need for the training of staff. The training program is clearly defined (twinning agreements, TAIEX, participation in IAIS seminars, individual consultations with other supervisory authorities, internal education programs).

- The Office reports that "improvement of accounting rules for insurance companies" has been under its permanent consideration and attention for many years.

66. The Office is aware of the need to strengthen supervisory capacity, and is undertaking a vigorous program of restructuring. They will add an additional 15 personnel to their number over the next three years. At the same time, they are providing training opportunities for existing staff that include attendance at seminars and also internships in other supervisory offices, particularly in Germany.

67. Under a special program funded by EU-Phare, an expert from the German office of insurance supervision will be in residence at the MoF for the next 7-12 months. The same program will fund training visits to the MoF by German experts on accounting and on asset management and the use of derivatives. Staff of the Office will also participate in on-site inspection teams working in Germany to gather practical experience. One staff member with actuarial qualifications will spend three months in on-the-job training with a cooperating German life insurance company. 


\section{B. Transparency of Insurance Regulation}

68. The assessment of transparency practices in insurance regulation in the Czech Republic was undertaken by a three-member staff team ${ }^{14}$ and was based on: (1) a pre-FSAP questionnaire response; (2) relevant laws; ${ }^{15}$ and (3) discussions with $\mathrm{MoF}$ officials, the Czech Insurance Association, and selected insurance companies. The assessment was based on the IMF Code of Good Practices on Transparency in Monetary and Financial Policies (MFP Transparency Code). The assessment took into account the implementation issues mentioned in the Supporting Document to the Code. The assessment also benefited from the discussions held with the authorities in the context of assessing the MoF's observance with the IAIS Core Principles for effective supervision.

\section{Institutional and market structure-overview}

69. The Insurance Act delegates the state insurance supervision in the Czech Republic to the MoF. Within the MoF, the Office is assigned the supervisory responsibilities over the insurance industry and the handling of consumer complaints. The Director of the Office reports to a Deputy Minister, who in turn reports to the Minister of Finance. The Minister of Finance acts upon recommendations made by the Office in issuing regulations, issuing and revoking licenses, etc. Accountability to Parliament lies with the Minister and not the Director of the Office.

\section{Main findings}

70. The responsibility for insurance supervision is fairly well-defined in the legislation. However, from the viewpoint of transparency and disclosure there are several factors that impede the process, making the overall observance with transparency and disclosure less than desirable. The Office is constrained by confidentiality requirements with respect to sharing and disclosing institution specific information. This hampers availability and access to data and information directly from the insurance supervisor. The Office also does not undertake onsite inspection and consequently the market and the general public has low confidence in the ability of the Office to supervise and disclose information that could provide signals on the effectiveness of the insurance regulatory polices in ensuring sound financial health of the insurance firms. In practice, the Czech Insurance Association, although not a legal SRO, collects data, monitors the financial health of its member firms and discloses information on a systematic basis to the market and general public. The Association also provides information relating to the regulatory framework and explains the technical changes with respect to insurance policies.

\footnotetext{
${ }^{14}$ Udaibir S. Das (IMF), Plamen Yossifov (IMF), and Donald McIsaac (World Bank).

${ }^{15}$ Insurance Act 363/1999 and the Decree No. 75/2000, Act on Accounting, Act on Auditing, and the Commercial Code.
} 
71. A factor seriously constraining the transparency of the Office is the lack of sufficient resources to discharge its primary objectives. It is however hoped that with the full implementation of the new Insurance Act that became effective in April 2000, the Office will adopt a more systematic approach towards public disclosure of insurance policies and initiate steps to improve its observance with the MFP Transparency Code.

\section{Clarity of roles, responsibilities and objectives of financial agencies}

72. While the Insurance Act explicitly bestows upon the MoF the responsibility for insurance supervision, the internal distribution of responsibilities for the conduct of financial policies in the area of insurance within the MoF is not clearly defined and publicly disclosed.

73. Government Decree No. 150/158, on which the formal responsibility of the Office for settlement of disputes between consumers and insurance companies is based, is outdated and the public is not informed about its provisions through other disclosure channels. Bringing this aspect of the legal framework up to date will enhance transparency by ensuring consistency of supervisory objectives with the current conditions of the insurance market, and will enhance public accountability in terms of comparing supervisory policies with the disclosed objectives.

74. In the area of insurance supervision, the broad objective of the MoF, its responsibilities and authority to conduct financial policies are specified in the Insurance Act. They are not, however, publicly disclosed in any other manner, such as through public reports, publications, commentaries. This aspect of transparency assumes particular importance in the context of the Czech financial system that is currently undergoing fundamental structural changes and where new owners are entering the market and are permitted cross holdings across banking and securities sectors. A clearer statement and public explanation by the MoF of its insurance supervisory responsibilities and authority to conduct financial policies would thus also allow the market and the public to have a clear understanding of how it relates to the rest of the system.

\section{Open process for formulating and reporting of financial policies}

75. With respect to openness and transparency of insurance policy making process, the $\mathrm{MoF}$, within the exiting framework of the Insurance Act and its practice appears to be following the spirit of the MFP Transparency Code. The Association is regularly consulted on regulatory issues, and the public is kept informed about technical changes in the regulatory framework through an MoF bulletin and the Association's website. Remaining transparency deficiencies relate to the lack of public disclosure of the operating procedures, used by the Office to conduct insurance supervision, and of the procedures and scope of the cooperation and information sharing between the $\mathrm{MoF}$, the $\mathrm{SC}$, and the $\mathrm{CNB}$. 


\section{Public availability of information on financial policies}

76. Public availability, on a timely and regular basis, of information on insurance policies is an important element of the transparency framework that strengthens accountability. Currently, the MoF does not publish reports on financial policies in the area of insurance. Furthermore, the MoF does not publish aggregate data on the insurance and reinsurance industry, with the exception of lists of licensed companies. The Insurance Act that entered in force in April 2000, however, requires the $\mathrm{MoF}$ to publish an annual report on its insurance supervisory activities to ensure consumer protection and on the situation on the insurance market. While the Office could use the general website of the MoF for dissemination and announcements, the website contains no information on its insurance supervisory policies. Information on the Office's responsibility for settlement of disputes between consumers and insurance companies, which derives from a government decree from 1958, is not publicly disclosed, as the staffing of the Office is inadequate to handle potential large amount of complaints.

\section{Accountability and assurances of integrity by financial agencies}

77. The MoF is accountable for its insurance supervisory policies to the government and Parliament. The Minister of Finance reports to the government on issues under its jurisdiction. Under general rules of accountability of the executive branch of the state, the Minister of Finance can be summoned by Parliament to report on policies in the area of insurance and answer questions. These modalities of accountability, however, are not defined specifically for the MoF insurance supervisory functions. In addition, MoF's internal governance procedures are not explained to the public.

\section{Recommended action plan and authorities' response}

\section{Table 12. Insurance Regulation Transparency: Assessment Recommendations}

\begin{tabular}{|c|c|}
\hline Subject & Recommendations \\
\hline $\begin{array}{l}\text { V. Clarity of roles, } \\
\text { responsibilities and objectives } \\
\text { of insurance superision } \\
\text { agencies }\end{array}$ & $\begin{array}{l}\text { The internal distribution of responsibilities for the conduct of financial policies } \\
\text { in the area of insurance within the MoF should be publicly disclosed. } \\
\text { Government Decree } 150 / 1958 \text {, on which the formal responsibility of the Office } \\
\text { for settlement of disputes between consumers and insurance companies is } \\
\text { based, is outdated. It should be brought up-to-date with the political and } \\
\text { economic changes in the Czech Republic since then, and the general public } \\
\text { should be actively informed about its implications for the insurance industry. } \\
\text { The broad objective of the MoF in the area of insurance supervision should be } \\
\text { publicly disclosed and explained through other channels in addition to } \\
\text { legislation. } \\
\text { The responsibilities and the authority of the MoF to conduct financial policies } \\
\text { in the area of insurance should be publicly disclosed through other channels in } \\
\text { addition to legislation and regulation. }\end{array}$ \\
\hline
\end{tabular}




\begin{tabular}{|c|c|}
\hline Subject & Recommendations \\
\hline $\begin{array}{l}\text { VI. Open process for } \\
\text { formulating and reporting of } \\
\text { insurance supervision policies }\end{array}$ & $\begin{array}{l}\text { Specific operating procedures for the conduct of insurance supervision by the } \\
\text { Office should be publicly disclosed. } \\
\text { The procedures and scope of cooperation and information sharing between the } \\
\text { MoF, the CSC, and the CNB, specified in the } 1998 \mathrm{MOU} \text {, should be explained } \\
\text { to the public. }\end{array}$ \\
\hline $\begin{array}{l}\text { VII Public availability of } \\
\text { information on unsurance } \\
\text { supervision policies }\end{array}$ & $\begin{array}{l}\text { The MoF should publish aggregate data on the insurance and reinsurance } \\
\text { industry. } \\
\text { The website of the MoF should provide information on its insurance } \\
\text { supervisory policies. } \\
\text { The maximum delay between the end of the budget year and the publication of } \\
\text { the Annual Report, specified in the latest amendments of the Act on Insurance, } \\
\text { should be significantly shortened. } \\
\text { Information on the Office's responsibility for settlement of disputes between } \\
\text { consumers and insurance companies should be widely disclosed to the general } \\
\text { public. The staffing of the Office should be increased to be capable of handling } \\
\text { the potential large amount of complaints. }\end{array}$ \\
\hline $\begin{array}{l}\text { Val Accountability and } \\
\text { assurance of integrify by } \\
\text { insurance supervision } \\
\text { agencies }\end{array}$ & Internal governance procedures in the MoF should be explained to the public. \\
\hline
\end{tabular}

78. In its response, the Office expressed the following reservations regarding the assessment:

- While agreeing that Government Decree No. $150 / 1958$ is somewhat out-of-date, the Office felt that the decree satisfies the present needs.

- The Office questioned the practicality of publishing the Internal Organization Rules of the MoF given their extensive coverage and frequent changes. In a follow-up discussion, the assessors explained that the assessment does not ask for this but rather for disclosing the general distribution of responsibilities between the Office and the other departments in the MoF. As a result of the discussion this objection was dropped.

- The Office objected to the recommended public disclosure of the procedures and scope of cooperation and information sharing between the $\mathrm{MoF}$, the $\mathrm{CSC}$, and the $\mathrm{CNB}$, specified in the $1998 \mathrm{MOU}$, further noting that this will require the consent of all parties involved.

- The Office noted that as long as its staff receive the audited financial statements of supervised companies by June 30 , the maximum delay between the end of the calendar year and the publication of its planned annual report (until September 30) is not so long. 


\section{IOSCO ObJectives AND Principles of Securities Regulation and TRANSPARENCY OF SECURITIES REgULATION}

\section{A. IOSCO Objectives and Principles of Securities Regulation}

79. The assessment of the Czech Republic's observance with IOSCO's Objectives and Principles was undertaken by a two-member team ${ }^{16}$ and was based on: (1) a review of the legal framework; (2) seven detailed self-assessment questionnaires completed by the staff of the Czech Securities Exchange Commission (CSC); (3) extensive discussions with the supervisory authorities, self-regulatory organizations, and market participants. The main objectives of the assessment were to determine the levels of compliance with the Objectives and Principles adopted by the International Organization of Securities Commissions (IOSCO) in September 1998, and to suggest areas where further developments may be appropriate to give better effect to the IOSCO Objectives and Principles, to improve the quality of regulation, or to facilitate market development.

\section{Supervisory framework}

80. The primary regulator of the securities markets of the Czech Republic is the CSC. The capital markets of the Czech Republic are young and the CSC is also a very young organization, having been established in April 1998. The CSC's functions and powers are to be found in the Securities Commission Act and various pieces of legislation governing the capital markets. The CSC is an independent statutory body, with limited obligations to report to both the Minister of Finance and the Chamber of Deputies of the Parliament of the Czech Republic. The CSC's responsibilities extend to the securities dealing of banks and, to that extent, banks in the Czech Republic that are subject to dual supervision by the CSC and the CNB. The supervision of pension funds is still shared with the Office of Insurance Supervision in the MoF, but there are plans to shift entirely the supervision of pension funds to the CSC during 2001.

81. Primary responsibility for policy formulation lies with the MoF. The MoF also prepares secondary legislation. The PSE performs a limited supervisory role, by monitoring trading on the Exchange and supervising the conduct of its members. From January 2001, the operator of the second securities trading system, RM-SYSTEM (RMS), is obliged to monitor trading on its electronic exchange also.

\footnotetext{
${ }^{16}$ Led by Andrew Procter, a Commission Member and Executive Director of the Hong Kong Securities and Futures Commission. Jeppe Ladekarl, Capital Markets Specialist in the Financial Sector Development Department of the World Bank, also contributed to the assessment.
} 


\section{Market structure}

82. The Czech Securities Market was created in the early 1990s, as part of a mass coupon privatization scheme that involved the introduction of around 1,800 publicly traded companies in the capital market, together with hundreds of newly created investment funds. The trading of the shares of companies and investment funds was conducted in two newly created exchanges, the PSE and the RMS. Both the PSE and RMS are authorized by the CSC. The PSE is authorized as an exchange, whereas the RMS has a special authorization under the Securities Act not unlike that of a broker. However, from January 1, 2001, RMS will be regulated in the same manner as the PSE, and will assume responsibility for some regulatory matters, including surveillance of trading on the RMS.

83. The PSE is an intermediated exchange with 54 members and approximately 140 listed securities. The PSE is an electronic exchange with an automated trading system. Its most important trading system is the SPAD system, which is used for the seven most active stocks and which accounts for more than 90 percent of all trades. Trading can also take place through two other channels: automatic trades at fixed or variable prices, or block trades effected off-market between PSE members and subsequently recorded on the PSE's trading system. Clearing and settlement of trades on the PSE is effected through a system operated by a subsidiary of the PSE, called UNIVYC.

84. The RMS is an electronic trading system accessible by the general public as well as by more sophisticated investors such as brokers or institutional investors. Approximately 2,100 publicly tradable securities can be traded in the RMS, but many of these securities are rarely traded. The regulatory authorities have introduced stricter requirements for publicly tradable securities that are expected to halve the number of securities tradable in the RMS. Access to the RMS is via a number of "share shop" locations (more than 100) throughout the country. Professional and institutional clients may also access the RMS through on-line terminals installed at their premises.

85. The TKD system is used for the issuance, registration and settlement of trades in short term instruments (maturity up to 1 year), including treasury bills and CNB bills. The TDK system operates on a gross and continuous basis. It runs in real time and provides for delivery versus payment. Cash settlement is in the clearing and settlement system of the CNB.

86. The Securities Center (SCP) is responsible for the registration of securities and debt instruments with maturity of longer than one year. The SCP was established under the Securities Act by the MoF. The Czech Republic is liable for the actions of the SCP. The SCP maintains registers of dematerialized and immobilized securities. Registration is presently to the level of the individual beneficial owner. Reforms to come into effect in 2001 will allow for registration in the name of a nominee. 


\section{Main findings}

87. Broadly speaking, the laws and regulations of the Czech Republic give sufficient functions and powers to the CSC to permit effective regulation of the securities markets. However, there are practical limitations on the capacity of the CSC to discharge its responsibilities. In many areas in which the law appears adequate and the functions and powers available to the CSC appropriate, the CSC lacks the resources to effectively discharge its responsibilities.

88. Table 13 provides a summary of the main findings of the assessment and related recommendations. The summary of the findings focuses mainly on shortcomings in terms of implementation of the IOSCO Objectives and Principles. It should be recognized from the outset that the focus of the summary table does not reflect the real and valuable progress made in terms of securities markets law in the Czech Republic in recent years. Neither does it reflect the major progress in regulation, supervision and enforcement achieved since the inauguration of the CSC in April 1998. Much has been achieved in a short period of time. It should, furthermore, be said that the CSC recognizes many of the shortcomings identified below and appears determined to overcome them. Some of those shortcomings are, however, of a type that may not be able to be addressed by the CSC alone.

Table 13. Summary of Main Findings and Recommendations

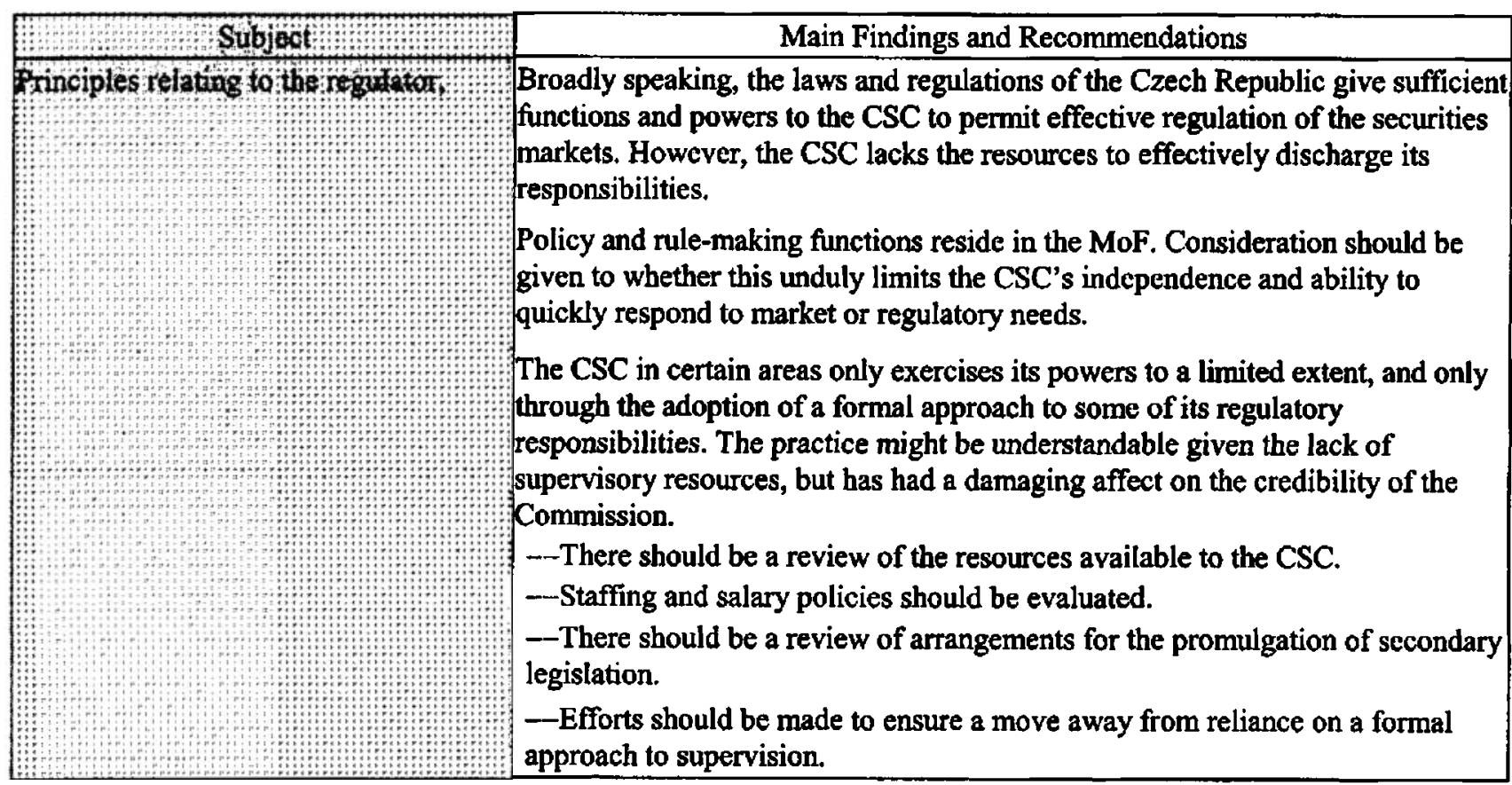




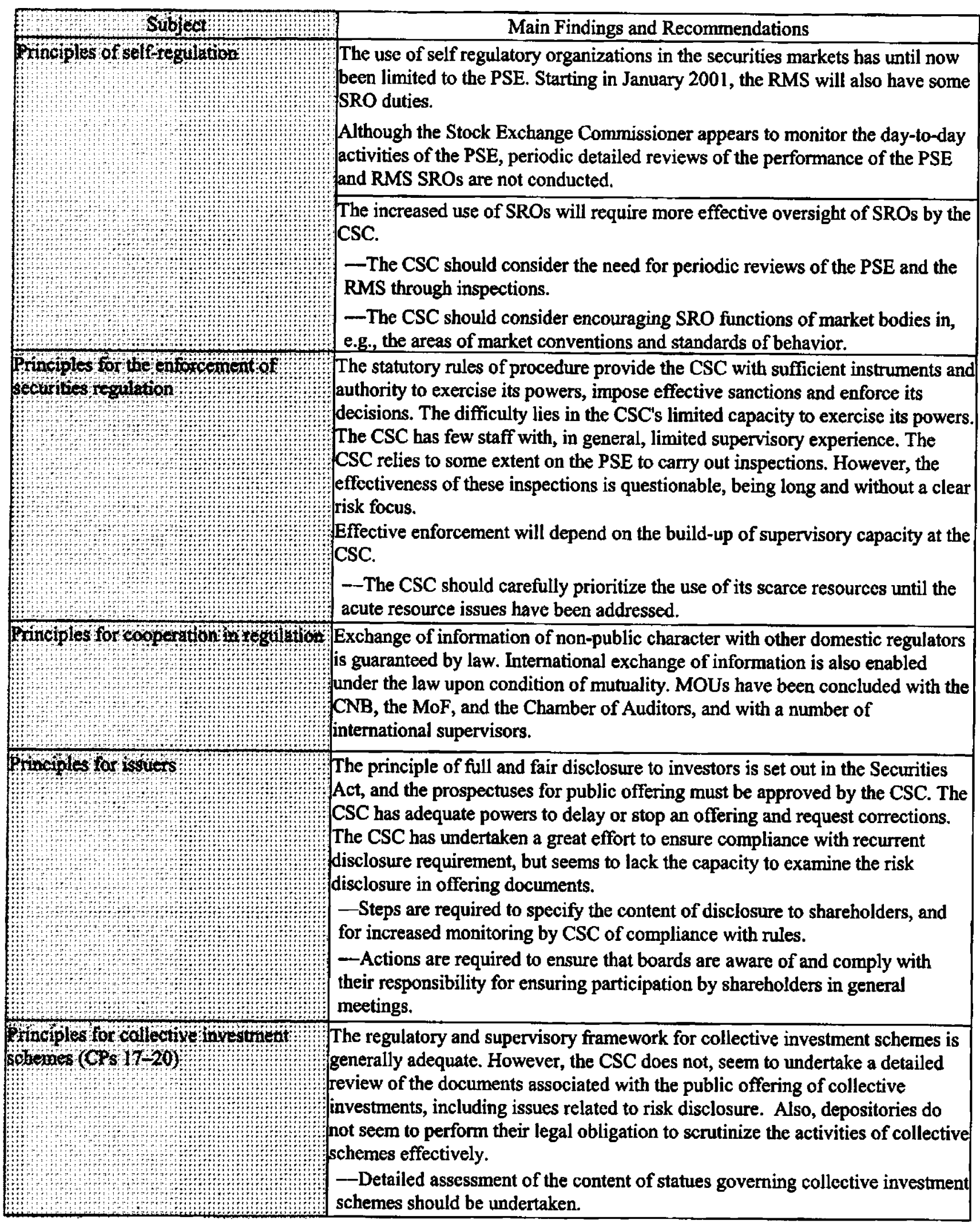




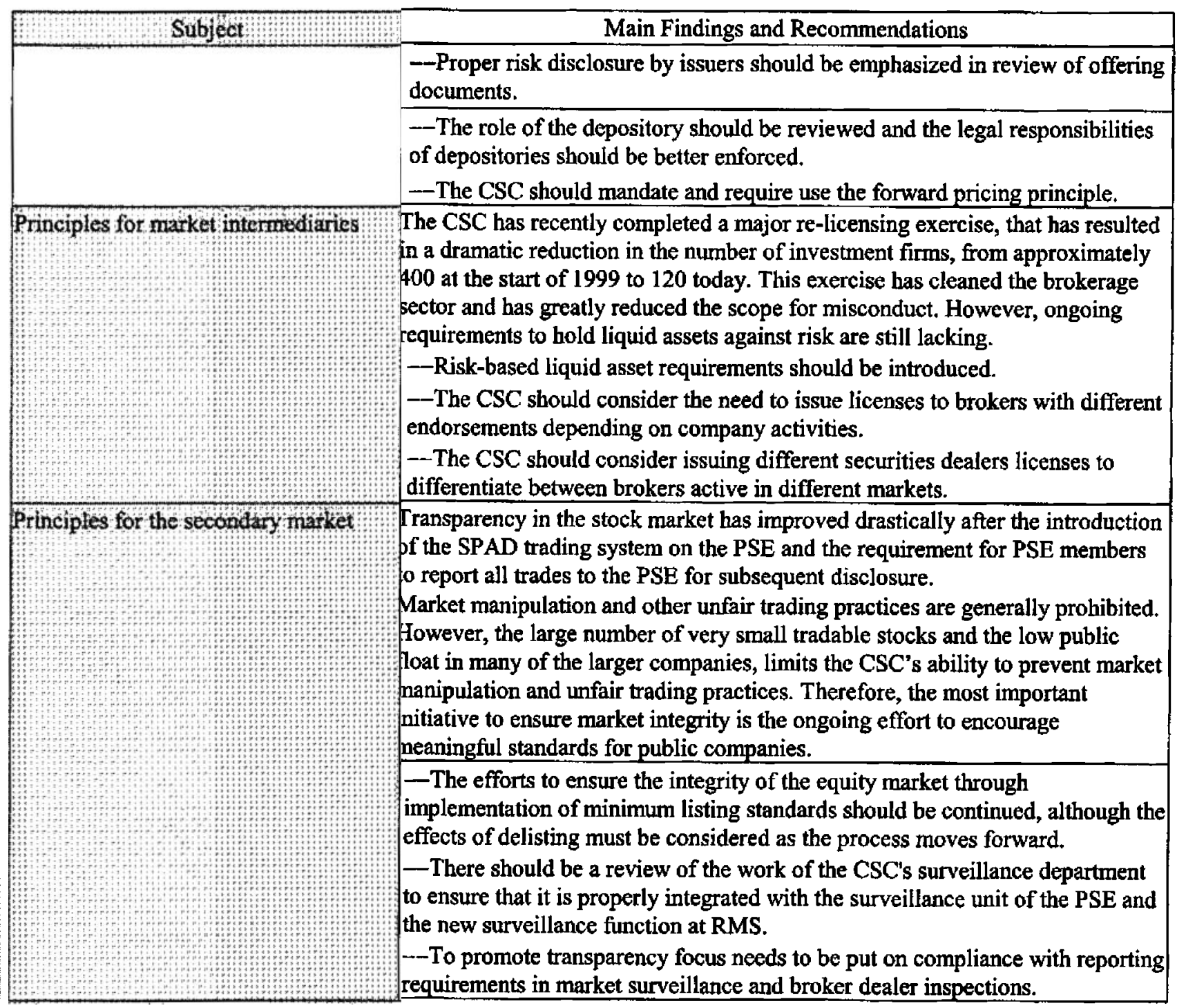

\section{Recommended action plan and authorities' response to the assessment}

\section{Recommendations}

89. The CSC cannot address the problem of lack of capacity alone. The first best solution requires recruitment of new staff at entry level, salary reviews to retain existing staff and targeted recruitment of seasoned professionals. For example, the CSC could benefit from additional operational risk management, audit experience, and market knowledge on its staff. Such solutions hinge on general budgetary reforms the CSC does not control. The CSC can, however, implement a number of initiatives to minimize the impact of the lack of capacity until its resources are strengthened. 
90. Clear prioritization concentrating resources where the highest concentration of risk is to be found is one way to minimize the consequences of lack of capacity. Identifying these areas would, however, require a change in the approach to supervision and regulation. The new approach would involve more focus on material issues and increased reporting requirements for intermediaries, enabling the CSC to conduct risk-based inspections. It might also entail a certain degree of concentration in terms of areas covered by the CSC. Taking on new responsibilities without adequate additional resources should be avoided.

91. Upgrade of existing resources could be another area of priority. A training needs assessment should be conducted. On-the-job training could be provided through cooperation with foreign supervisors on an ad hoc basis, or a twinning arrangement could be sought established for a more formal longer-term relationship. On-the-job training could, however, also be provided domestically through cooperation with the Chamber of Auditors or the CNB. Having staff participate in a audit of a financial institution (with the consent of the institution) could provide valuable insight, as could active participation in inspections led by experienced banking supervisors. Experienced and trained staff should train other staff rather than conduct day to day business so as to fully exploit and spread new knowledge obtained through out-of-house experiences. There is, however, a limit to what can be achieved through training because staff in some areas are not trained in academic disciplines well suited to their responsibilities.

92. A staff exchange program with the banking supervisors could also provide valuable knowledge transfer for both institutions. Interest from CNB staff in secondment to the CSC could also be explored. A number of secondments for one or two years of seasoned staff from the CNB to the CSC could contribute to a fast creation of a critical mass of experience and supervisory knowledge at the CSC.

\section{Response to the assessment}

93. The CSC has welcomed most of the findings and recommendations of the assessment. The CSC stresses that the current staff, though young, is competent and quickly developing the skills needed for efficient supervision of the securities markets.

\section{B. Transparency of Securities Regulation}

94. The assessment of CSC observance with transparency practices relating to securities regulation was undertaken by a two member staff team ${ }^{17}$ and was based on: (1) a pre-FSAP questionnaire response; (2) relevant laws; ${ }^{18}(3)$ self-assessment of the IOSCO Core

${ }^{17}$ Udaibir S. Das and Plamen Yossifov (IMF).

${ }^{18}$ The Securities Act (1992), The Securities Commission Act (1998), the Stock Exchange Act, the Bonds Act (1990), and the Investment Companies and Investment Funds Act (1992) as amended. 
Principles; and (4) discussions with SC officials and select securities brokers. The assessment was based on the IMF Code of Good Practices on Transparency in Monetary and Financial Policies (MFP Transparency Code). The assessment has taken into account the implementation issues mentioned in the Supporting Document to the Code. The assessment also benefited from the discussions held with the authorities in the context of assessing CSC's observance of the IOSCO Core Principles for effective regulation and with the CNB's observance of the Basel Core Principles for Effective Banking Supervision.

\section{Institutional and market structure-overview}

95. The primary responsibility for formulating and issuing regulations relating to the securities market, including the prudential framework and policy issues are vested with the MoF. The CSC is the independent statutory body responsible for the supervision of the capital markets, including responsibility for ensuring that the laws and regulations are being implemented. Wherever legal or regulatory changes are required, the CSC recommends and drafts the relevant regulation for the consideration of the MoF. It also has the responsibility to inform the public and capital market participants about the policies, practices and performance of the capital market. Thus, while the CSC is primarily a licensing, supervisory, and enforcement financial agency, it works closely with the MoF on the regulatory side as well. This assessment thus focuses on the transparency practices as they relate to the CSC as the primary agency responsible for supervising the capital market activities in the Czech Republic. Where applicable, the assessment also addresses the public disclosure and transparency practices as they relate to the MoF.

\section{Main findings}

96. The supervisory responsibilities ${ }^{19}$ of the CSC are defined in numerous legislative acts and are not stated in their entirety in the Securities Commission Act (CSC Act). The government has set up a working group of experts from the $\mathrm{CSC}$ and the $\mathrm{MoF}$, and visiting EBRD technical advisors, which has prepared a report on the regulatory framework of the capital market supervision. One of the main recommendations of this working group is that the CSC Act, the Stock Exchange Act and other relevant legislation with the exception of the CSC Act should be consolidated in one law on the capital market. If this initiative materializes, it would be advisable to amend the CSC Act to state explicitly all supervisory responsibilities of the Commission as stipulated in the new consolidated law.

\footnotetext{
${ }^{19}$ The CSC supervises the activities of institutional investors (banks which trade with investment instruments on the capital market on their own account, investment companies, investment funds, pension funds and insurance companies that invest and trade on the capital market), securities dealers, public markets organizers, providers of clearing and settlement systems, issuers and owners of securities or other investment instruments.
} 
97. The CSC uses multiple disclosure channels to inform capital market participants and the general public on regulatory developments and its supervisory actions. Operating guidelines on how the CSC's discretion is exercised on issues such as licensing and imposition of penalties are made public. The CSC, however, clearly recognizes that a lot more needs to be done to improve transparency of the regulatory and supervisory system.

\section{Clarity of roles, responsibilities and objectives of financial agencies}

98. The CSC Act clearly recognizes the need for cooperation and information sharing with the MoF and the CNB. While there exists a 1998 MOU on cooperation and information sharing between the $\mathrm{CNB}$, the $\mathrm{MoF}$, and the $\mathrm{CSC}$, it remains an internal document, with ambiguity regarding formal procedures for information sharing and consultation. There was no consistent view on how the MOU actually worked in practice. This issue becomes important both from the viewpoint of transparency to the market agents, who may spot opportunities for regulatory and informational arbitrage among the domestic regulators out of ignorance that a formal information sharing arrangement exists. It also assumes importance in the context of providing greater clarity of the operational relationship enjoyed by the different financial agencies.

\section{Open process for formulating and reporting of financial policies}

99. The CSC discloses and explains the regulatory framework relating to the securities regulation. However, specific operating procedures through which the supervision and oversight of the capital market is carried out are not systematically disclosed and periodically explained. Knowledge of operating procedures allows the market and the general public to have a better understanding of the rules and processes and enhances the credibility of the operating process. It also improves wider acceptance and accountability, as such disclosure allows the market and the public to assess the adequacy of the procedures and measure outcomes of the regulatory and supervisory actions.

100. While the CSC has entered into several agreements with foreign securities supervisors, the formal procedures for sharing information is not disclosed. Through a press release, however, the CSC makes an announcement each time an agreement is entered into.

\section{Public availability of information on financial policies}

101. Publication of periodic reports by a securities regulatory agency on the major developments in the capital markets helps to build public awareness and understanding of the functioning of the agency. It also promotes market stability. While the CSC has a publication program, it has been erratic at times. The delays between the end of the reference period and the issuance of the semi-annual and annual reports are too long. Besides listings of newly licensed capital market intermediaries and of those which licenses were suspended, the annual, semi-annual, quarterly, and monthly reports of the CSC do not provide information and aggregate data on capital market developments. One of the main objectives of the CSC- 
investor rights protection-is not specified in relevant legislation, and is not explicitly referred to in the CSC's reports.

\section{Accountability and assurances of integrity by financial agencies}

102. Finally, in terms of accountability and integrity of supervisory operations, internal governance procedures applicable to the CSC staff responsible for insurance supervision are not explained to the public.

\section{Recommended action plan and authorities' response}

Table 14. Securities Regulation Transparency: Assessment Recommendations

\begin{tabular}{|c|c|}
\hline Subjos: & Recommendations \\
\hline 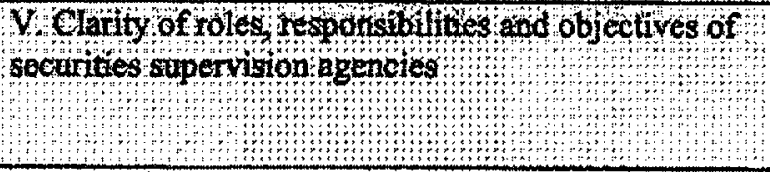 & $\begin{array}{l}\text { The scope and nature of the MOU between the CNB, } \\
\text { the MoF, and the CSC on cooperation and information } \\
\text { sharing in the area of capital markets should be } \\
\text { publicly disclosed. }\end{array}$ \\
\hline 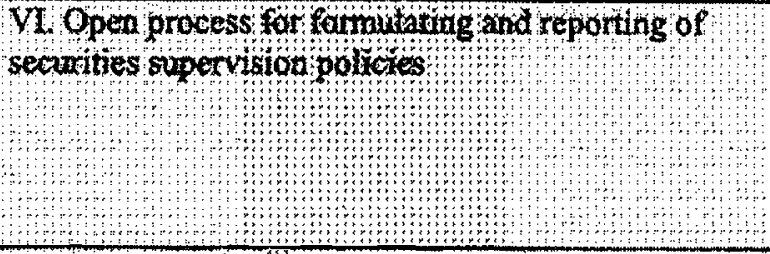 & $\begin{array}{l}\text { Specific operating procedures for the conduct of } \\
\text { capital market supervision by the CSC should be } \\
\text { publicly disclosed. } \\
\text { The CSC should ensure the timeliness of its published } \\
\text { reports. }\end{array}$ \\
\hline $\begin{array}{l}\text { VI Public avalab ift of information on securities } \\
\text { supervision polices }\end{array}$ & $\begin{array}{l}\text { The CSC should publish inforrnation and aggregate } \\
\text { data on capital market developments in its annual, } \\
\text { semi-annual, and quarterly reports. } \\
\text { One of the main objectives of the CSC-investor } \\
\text { rights protection-should be explicitly specified in } \\
\text { relevant legislation and more actively disclosed } \\
\text { through the CSC's publications. }\end{array}$ \\
\hline 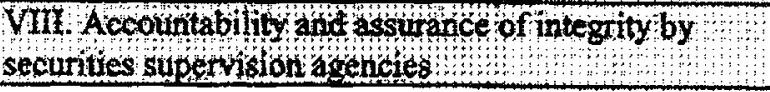 & $\begin{array}{l}\text { The internal audit procedures of the CSC should be } \\
\text { explained to the public. }\end{array}$ \\
\hline
\end{tabular}

103. The CSC was in agreement with the assessment's findings and recommendations.

\section{OECD Corporate Governance Principles}

104. The assessment of the quality of corporate governance in the Czech Republic was performed as part of the joint FSAP for the Czech Republic. The assessment was conducted by determining the levels of observance with the OECD Principles of Effective Corporate Governance (OCG). The assessment also identifies areas where further development may be appropriate. 
105. The assessment ${ }^{20}$ drew upon the World Bank Capital Market Review, the Czech Republic (1999), and was based on a review of several pieces of legislation and extensive discussions with government officials, financial supervisors, and numerous segments of the private sector. In particular, the assessment reflects extensive technical discussions with the MoF, MoJ, CSC, PSE, the Chamber of Auditors, the Union of Accountants, the Institute of Directors, the Union of Investment Companies, major listed companies, and professional services firms. The review also is based upon self-assessment questionnaires completed by the CSC for the purposes of an assessment of the Objectives and Principles of Securities Regulation of the IOSCO, and in particular on a questionnaire on corporate governance.

\section{The legal framework affecting corporate governance}

106. For the purposes of the OECD Principles, corporate governance is "that structure of relationships and corresponding responsibilities among a core group consisting of shareholders, board members and managers designed to best foster the competitive performance required to achieve the corporation's primary objective." (A Report to the $O E C D$ by the Business Sector Advisory Group on Corporate Governance, April 1998, page 13).

107. During 2000, a major package of legislation affecting corporate governance was approved by the Parliament to come into force on January 1, 2001. Among the more important elements of this package are extensive changes to the Commercial Code, the Securities Act, and the Auditing Act. Additional legislative changes are under consideration or are already under discussion in Parliament, including amendments to the CSC Act and the Law on Investment Companies and Investment Funds. A number of the changes brought about by the package are novel to Czech law or substantially alter the responsibilities and rights of companies, board members, shareholders, and auditors. Because of the timing of this package, companies, investors and regulators are still attempting to understand how these provisions will operate in practice. For the same reason, complete English translations of the package were not available during the review phase. This assessment should therefore be read with caution, pending possible modifications in the light of a review of complete translations of the legislation. Definitive interpretations by the courts of some key provisions will also be required before there can be a reasonable level of predictability as to how those provisions are to be applied.

108. It must be pointed out that in most countries banks and insurance companies are typically subject to specific and stricter governance rules, relative to those applied to all other financial and non-financial companies. This includes, for example, the duty of boards to implement and monitor systems of risk management and internal controls. This difference is justified due to the nature of the business and the critical importance of minimum capital

\footnotetext{
${ }^{20}$ Prepared by Douglas Webb (World Bank).
} 
requirements in these industries. The assessment of corporate governance does not comprise an analysis of specific governance rules for banks and insurance companies. This analysis is done in the specific assessments for banks and insurance companies.

109. The courts are a key component of an effective corporate governance system. The courts play three important roles. First, court decisions interpreting the relevant laws provide guidance to regulators, companies, board members, managers, auditors, and investors on the manner in which the laws should be applied in similar situations. Second, the courts are responsible for deciding appeals from regulatory decisions, and therefore are an important check-and-balance to broad regulatory powers. Finally, the courts have the authority to award damages in civil suits for breach of corporate governance obligations where the law provides for such damages claims, and to impose criminal penalties for serious misconduct. Though this assessment does not represent an evaluation of the capacity and effectiveness of the court system, conclusions are drawn as to the impact on corporate governance of weaknesses in the court system.

\section{Main findings}

110. There has been a concerted effort from the side of the Czech authorities to improve the mechanisms of corporate governance in the Czech Republic. The most clear example of this effort is the recent package of amendments to the Commercial Code, the Securities Law, the Auditing Law and other related pieces of legislation. The amendments to the Commercial Code were particularly extensive, and will tend to improve significantly the internal mechanisms of governance. However, some regulatory gaps still remain, particularly in the areas of insider trading and disclosure, the rules for membership in supervisory and management boards, and the independence and legal liability of external auditors.

111. There has been less success in improving the external mechanisms of governance. As examined in more detail in a separate assessment, creditor rights remain weak in the Czech Republic, despite recent amendments to the Bankruptcy and Composition Act, and the introduction of a new Law on Public Auctions. The lack of strong creditor rights weakens the important monitoring and disciplining role of creditors.

112. It is also essential to stress that the quality of corporate governance, whether internal or external, depends not only on well-written regulations, but also on their enforcement by supervisors, SROs and the court system. Progress in this area has been unsatisfactory, as supervisors and SROs still suffer from lack of capacity and skills, and the court system remains slow and inefficient. These institutional deficiencies bave frequently led to a general skepticism among market participants that the new and improved regulatory framework will be effectively enforced. This assessment reflects both the current weak effectiveness of enforcement and the sound new legal framework that applies to corporate governance since the beginning of 2001. When implementation and enforcement of the new laws and regulations are strengthened, the Czech Republic will observe most of the principles on corporate governance. 


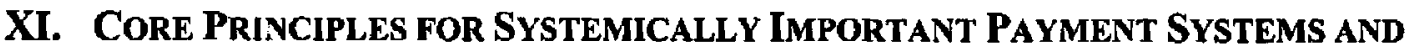 TRANSPARENCY OF PAYMENT SYSTEM OVERSIGHT}

\section{A. The Core Principles}

113. This assessment pertains specifically to the interbank payment mechanism known as the Clearing and Settlement Center of the CNB, often referred to as the Clearing Center (CC). This electronic, real-time, gross-settlement (RTGS) system is owned and operated by the central bank, and it is the only payment clearing mechanism in the Czech Republic, handling both large and small value transactions. The direct participation in the $\mathrm{CC}$ is compulsory for all licensed banks. The system processes transactions that are initiated either directly by banks, or indirectly as a result of their customers' credit transfer orders, cheques, payment card or stock exchange purchases. In sum, the $\mathrm{CC}$ is the heart of the Czech payment system. It is systemically important, and thus the subject of assessment according to the Core Principles for such systems issued by the Committee on Payment and Settlement Systems (CPSS).

114. The assessment ${ }^{21}$ was based on information provided by the CNB in the form of the BIS Red Book entitled Payment Systems in the Czech Republic, the Czech chapter in the ECB Blue Book on payment systems in countries that have applied for membership in the $\mathrm{EU}$, answers to the IMF questionnaire with regard to payment and securities clearing and settlement issues, the 1992 Regulation of the State Bank of Czechoslovakia, the 1993 Czech National Bank Act, and the text of the revised National Bank Act that was adopted by Parliament during the mission's stay in Prague, together with a principles document for an Act on Payment Systems. These sources were supplemented by discussions held with officials of the CNB, the Bankers' Association, and officials of UNIVYC, the clearing subsidiary of the PSE. A fuller assessment of the payments system broadly defined was limited by the fact that time did not permit an examination of many of other relevant laws such as the Czech Republic's commercial code and its bankruptcy law.

\section{Institutional setting and market structure}

115. The CNB and the licensed banks form the backbone of the Czech payments system. While the banks provide most of the payment services to the general public, the CNB plays the principal role in developing and operating the interbank clearing system, the $\mathrm{CC}$. The CNB provides the operating accounts for the government, and the deposit accounts that banks must open at the CNB are used for the settlement of all payment transactions between these institutions. The rules governing the use of these accounts are found in the 1992 Regulation promulgated by the CNB.

${ }^{21}$ Conducted by James Dingle (Bank of Canada). 
116. As in many other countries, there are close links in the Czech Republic between the securities markets, the foreign exchange market, and the payments system. There are three securities clearing mechanisms, each of which uses the CC system in order to effect the necessary settlements each day. The koruna leg of foreign exchange transactions involves payments moving between pairs of banks, via the $\mathrm{CC}$ system, two business days after the purchase and sale contracts are negotiated.

117. The CNB has explicit legal responsibility for the Czech payment system. Section 2 of the new National Bank Act states the primary objective of the Czech central bank shall be to maintain price stability. In accordance with this objective, the CNB shall "administer payments and clearing between banks, promote their smooth and efficient operation, and contribute to ensuring sound and efficient payment systems and to their development." This citation indicates that such smooth and efficient operations are viewed as necessary conditions for the effective conduct of monetary policy. The CNB's basic approach to payment system policy is that it should develop and run the $\mathrm{CC}$ at the heart of the system, marshalling the cooperation of the private banks when necessary.

\section{General preconditions-overview}

118. There is not as yet a specific law regulating the payment system in the Czech Republic. Payments involving private individuals and legal entities are considered to occur in a civil law relationship and hence they are subject to the Civil Code (1964) and the Commercial Code (1992). These codes also contain the basic principles on which banking contracts are based. Interbank payment and settlement arrangements are shaped by the 1992 Regulation that is binding on all banks in the Republic. In the same year, the State Bank of Czechoslovakia issued the General Terms and Conditions (amended in 1994 and 1997 by the CNB) that serve, on the basis of a "gentleman's agreement" with the banks, as the model for these institutions when they create their own terms and conditions for opening accounts and providing payment services to customers. The principles of a uniform interbank payment system, as well as the rules for handling misdirected payments, are stipulated in the 1998 amendment of the 1992 Banking Act. A law providing the rules on bankruptcy was passed in 1992 and amended in 1998. At the present time, a bank ceases to function legally only when the appropriate statements are physically posted by officials of the relevant court. The CNB would immediately thereafter block all further $\mathrm{CC}$ transactions involving that institution; it would not unwind earlier transactions.

119. The CNB has drafted the principles for the Payment System Act that is expected to become effective in 2001. Upon its passage, this Act of the Czech Parliament should achieve full compliance with the relevant EU Directives, including those concerned with cross-border payments and finality, as well as with the EU recommendation concerning transactions made using electronic payment instruments. 


\section{Main findings}

120. The CC system observes all but two of the applicable CPSIPS. With respect to Principle 1, the system largely observes the requirement for a well-founded legal basis at the present time. Moreover the planned Payment Systems Act should bring the legal basis into harmony with the requirements of the EU (and this Principle) in the course of 2001. With respect to Principle 10, the system's transparency could be improved by the publication of aggregate information on emergency support by the central bank, as applicable. Accountability could be strengthened by an amendment to the CNB Act that provides adequate legal protection for central bank officials while they are performing payment-related duties. The CNB should enhance the transparency of its actions in the payments field by publishing a well-designed booklet that would provide a description of the CC system for an international readership.

Table 15. Summary of Main Findings of the Core Principles for Systemically Important Payment Systems

\begin{tabular}{|c|c|}
\hline Subjest & Main Findings and Recommendations \\
\hline $\begin{array}{l}\text { Well-founded legal basis Xall } \\
\text { relevant jurisdictions }\end{array}$ & $\begin{array}{l}\text { The planned Payment System Act represents an important component of the } \\
\text { necessary legal basis for the future of the Czech Republic in the EU. }\end{array}$ \\
\hline $\begin{array}{l}\text { Governance of the system s oculd be } \\
\text { effective, transparent and ocootwatable }\end{array}$ & $\begin{array}{l}\text { Recommendations are made with respect to the publication of aggregate } \\
\text { information on emergency support by the central bank, and concerning adequate } \\
\text { legal protection for officials while performing payment-related duties. See also } \\
\text { the assessment according to the Code of Good Practices on Transparency in } \\
\text { Monetary and Financial Policy. }\end{array}$ \\
\hline Responsibilities of the central bank in & $\begin{array}{l}\text { While these responsibilities are met by the CNB, there would be a social benefit } \\
\text { from a well-designed booklet on the CC system edited for a broad readership. }\end{array}$ \\
\hline
\end{tabular}

121. The CNB was in agreement with the assessment findings.

\section{B. Transparency of Payment Systems Oversight}

122. The assessment of transparency practices in payment systems oversight in the Czech Republic was carried out by a three members team ${ }^{22}$ and was based on: (1) a pre-FSAP questionnaire response; (2) relevant laws and regulations; ${ }^{23}$ and (3) discussions with officials from the Payment Systems Department of the CNB. The assessment was based on the IMF Code of Good Practices on Transparency in Monetary and Financial Policies (MFP

${ }^{22}$ Udaibir S. Das and Plamen Yossifov (IMF), James Dingle (Bank of Canada).

${ }^{23}$ Act No 6/1993 on the Czech National Bank (CNB Act), as amended through December 2000, Act 21/1992 Coll. on Banks (Banks Act), as amended through December 2000, and CNB Regulation on Interbank Relations and Settlement of 1992 as amended. 
Transparency (Code). The assessment has taken into account the implementation issues mentioned in the Supporting Document to the code.

\section{Institutional and market structure-overview}

123. The CNB is the sole supervisor of payment systems in the Czech Republic. Under the current provisions of the Banks Act, the CNB also has a monopoly over the establishment and management of the interbank payment systems. This is expected to change in the near future, even though amendments in the Banks Act to that effect were recently rejected by Parliament. Currently, there is only one interbank payment system, namely the CC, which the CNB has operated since 1992.

124. Within the CNB, the Payment Systems Department is responsible for managing the non-cash payment system, for developing and running the automated accounting and payment system at the CNB and the interbank settlement system (the CC). A member of the CNB's Bank Board oversees the activities of this department and submits for Board approval proposals for changes in secondary legislation on payment systems' operation and oversight. In carrying out its supervisory responsibilities over the payment systems in the Czech Republic, the CNB is guided by the objective, stated in the CNB Act, to promote the smooth and efficient operation of the payments and clearing between banks, and contribute to ensuring sound and efficient payment systems and to their development.

\section{Main findings}

125. The institutional framework, responsibilities and objectives of payment systems oversight in the Czech republic are clearly defined in relevant legislation. The central bank, however, should be more proactive in explaining them to the general public in its regular publications.

126. The regulatory framework and operating procedures are readily available to the participants in the interbank payment system in the form of relevant legislation and regulations, and bilateral agreement between them and the central bank. Substantive changes in regulations and procedures are discussed with the Committee on Payments and Payment Instruments of the Bankers' Association. More remains to be done in increasing the awareness of the general public on these issues. In particular, the chapter on the payment system in the annual report of the CNB is limited to general discussion of trends in the volume and value of transactions. It lacks a detailed description of the working of the payment system, explanation of its operating procedures (such as risk management policies) and a more detailed analysis of the transactions carried out through it (foreign exchange versus domestic currency settlements, counterparties, etc.).

127. In terms of public availability of information, the central bank presents the developments in the payment system in its annual report. Senior officers of the Payment System Department of the CNB participate in seminars and conferences both in the Czech Republic and abroad, on which they present the objectives of state oversight over the 
payment system and its performance. The CNB's internal governance procedures are not publicly explained.

\section{Recommended action plan and authorities' response}

Table 16. Payment Systems Transparency: Assessment Recommendations

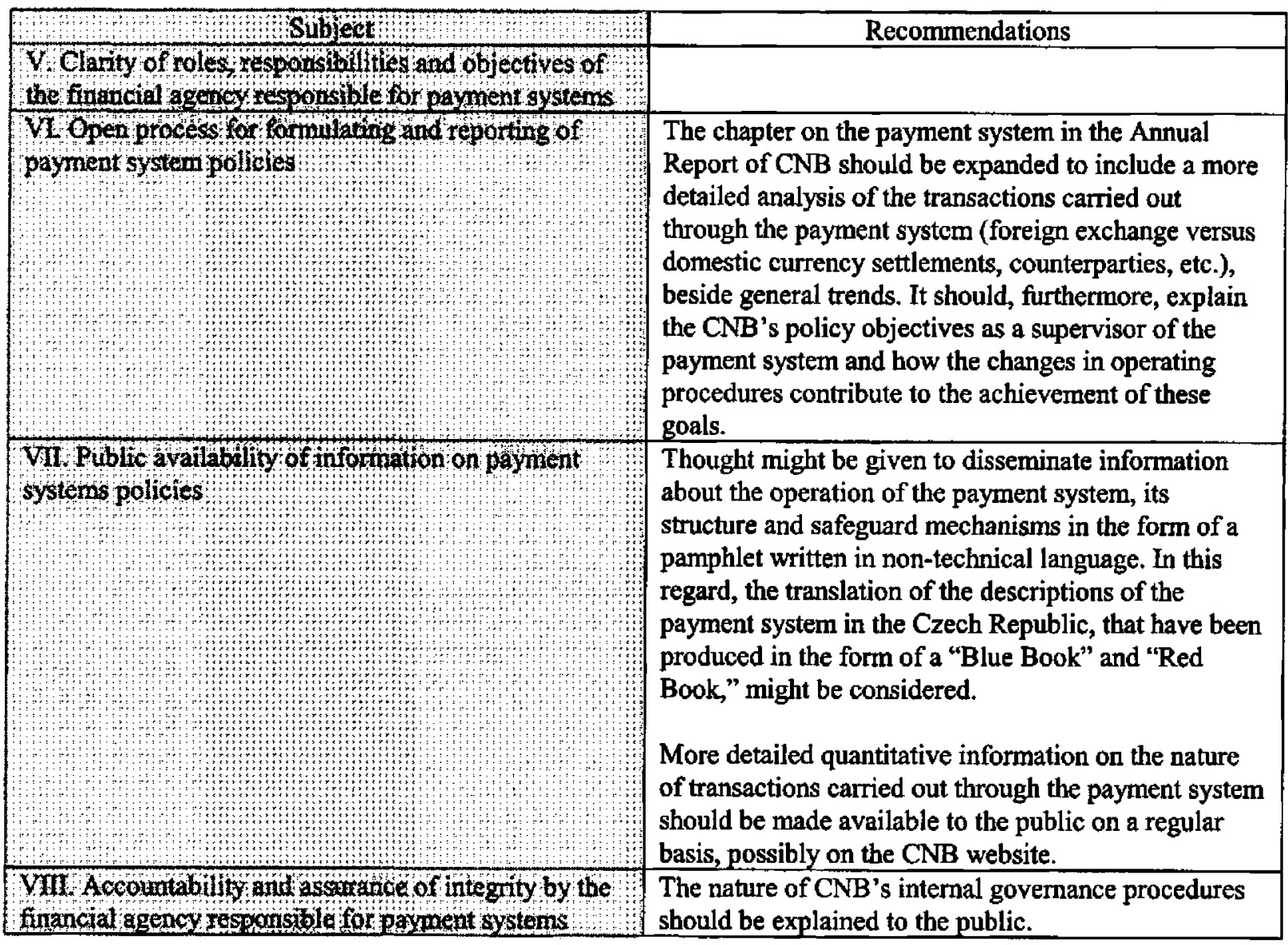

128. The CNB was in agreement with the assessment's findings and recommendations. 